Historic, Archive Document

Do not assume content reflects current scientific knowledge, policies, or practices. 
conpley
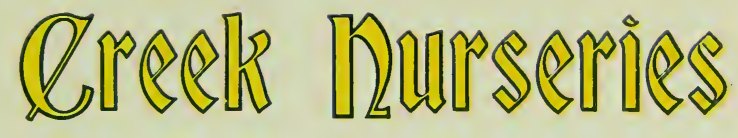

INCORPORATED

\section{Macclenny, Florida}

\section{F. BARBER, PRESIDENT J. E. BARBER, SECRETARY}

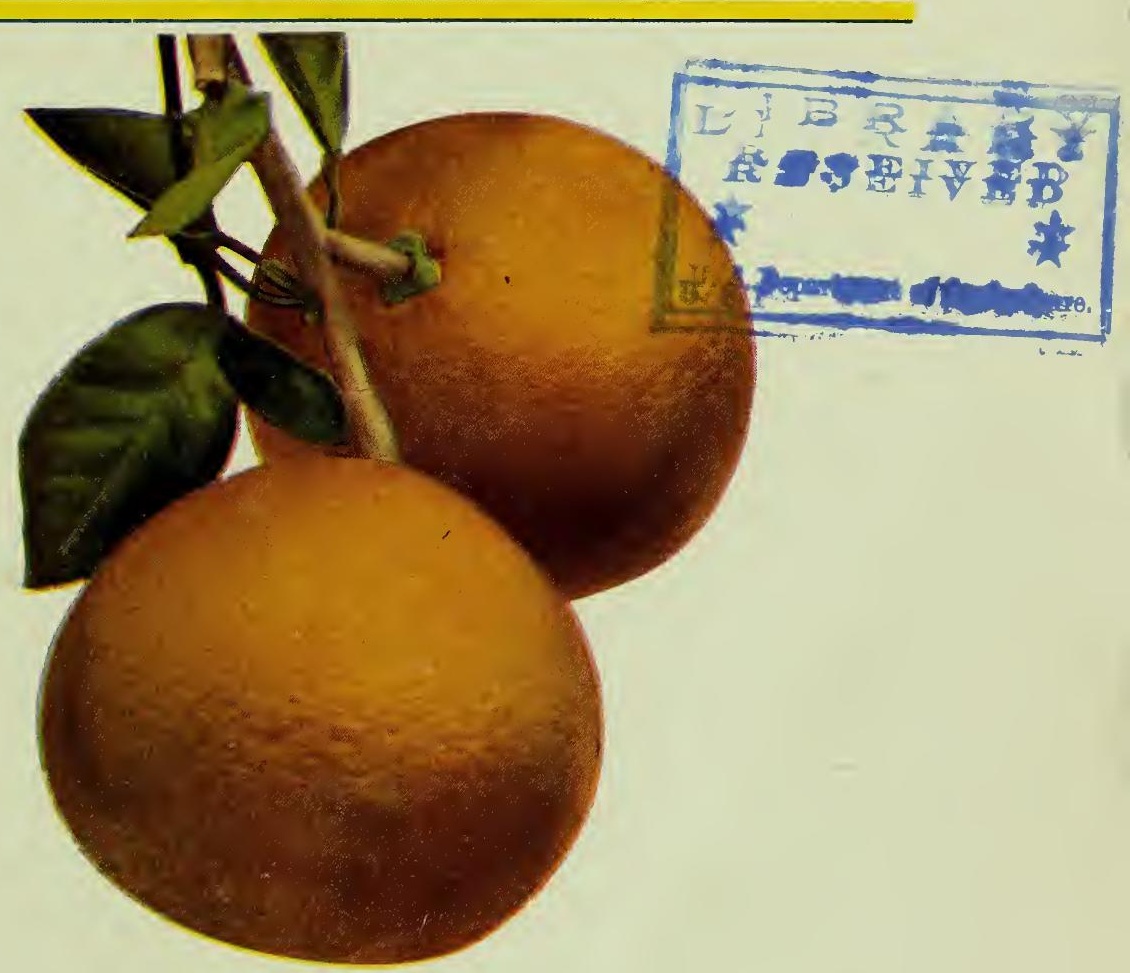

Descriptive latalogue

$1911=1912$ 


\section{Business Terms and Conditions}

Shipping Season. November to March. Citrus trees can, however, be shipped any time of year, but should go by express during hot weather. Orders sent in during shipping season will be forwarded as soon as possible unless otherwise instructed. Orders booked in advance of season will be forwarded as soon as may be after opening of season, unless to be held for definite shipping date.

Method of Shipment. Unless definite instructions accompany orders, trees will be boxed or baled, as best meets requirements of order, and forwarded by freight or express, according to our judgment.

Prices shown in this catalogue are net for trees and plants carefully packed and delivered f. o. b. cars at Nursery, shipping point. Five, fifty and five hundred trees of one class, take ten, hundred and thousand rates, except on badly assorted orders or long lists of a few trees each of many varieties.

Terms. Cash with order during shipping season. If order is placed in advance of season, a payment of 25 per cent of order to accompany it, balance before shipment, will generally be satisfactory.

Transportation at Purchaser's Risk and Expense. Our responsibility ceases upon delivery in good order to forwarding companies. Claims for loss or damage in transit should be made upon latter. We will, however, start a tracer for delayed shipments, if notified, and use every means at our command to secure prompt delivery, or recovery, in case of damage or loss. All freight and express charges at purchaser's expense.

Minimum Orders. We prefer not to accept orders for less than $\$ 2.00$.

Shipping by Mail. We reserve the right to turn down such orders, if we cannot conveniently handle them. In ordering trees sent by mail, add 15 per cent of amount of order for packing and postage. Only very small trees and plants can be sent in this way, hence we cannot guarantee trees or plants to come up to smallest regular size listed.

We Guarantee all stock sent out to be well grown, well rooted, true to name, properly packed and shipped according to instructions. Our liability under this guarantee is limited in amount to the original price received.

Substitution. Unless instructed to the contrary, we substitute where varieties or sizes ordered are exhausted, as we find that our customers generally prefer that we use our judgment in such cases; but, in all cases varieties sent are properly labeled and invoices show the substitute as well as variety substituted for.

Complaints or Claims. We use every possible precaution to prevent errors, but when, by any possibility, they do creep in, we will deem it a favor if you will report at once. Claims should be made within ten days after receipt of goods.

Location. The Turkey Creek Nurseries are one mile south of Macclenny (the county seat of Baker County), Florida, on Seaboard Air Line Railway, 28 miles west of Jacksnnville; also one mile northwest of Nursery, Fla., a station on Atlantic Coast Line Railway, 28 miles west of Jacksonville.

Telegraph Station, Macclenny, Fla.

Long Distance Telephone in our office-call Macclenny.

Code Address, "Barber, Macclenny, Florida." We use A. B. C. Code, fifth edition; also American Association of Nurserymen's Code.

Address all orders and communications to

TURKEY CREEK NURSERIES, 


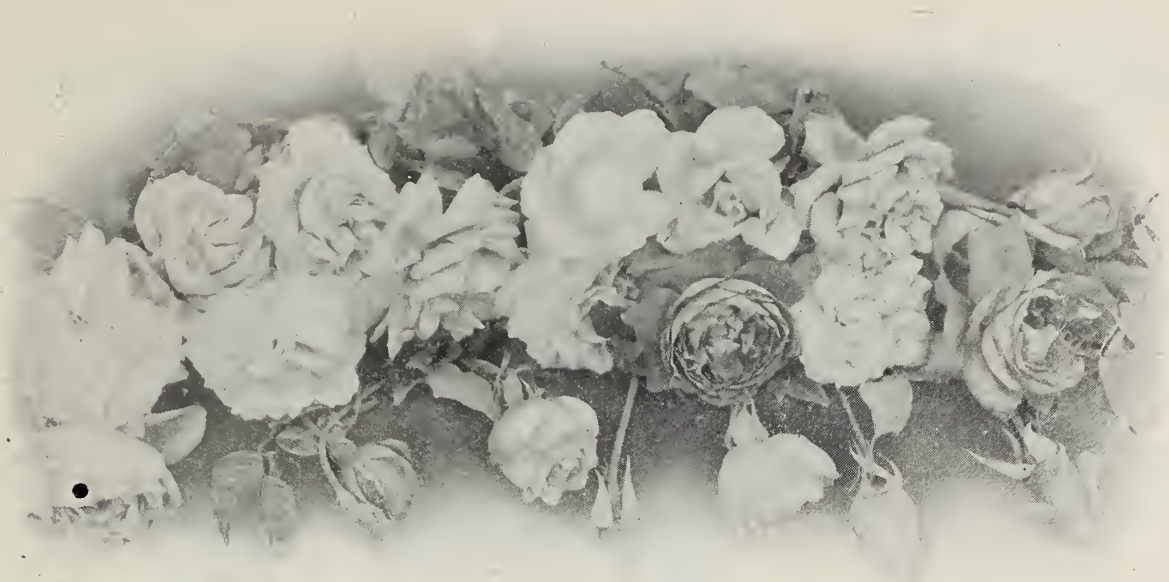

\section{Announcement}

In sending out this, our 16th annual catalogue for 1911 and 1912 , we are offering the most complete line of stock we have ever grown.

Our soil (a sandy loam underlaid with clay and naturally well drained) and climatic conditions are ideal for growing strictly first class stock. We exercise, at all times, every precaution to keep varieties pure and true to name, using only skilled labor in all departments of our nurseries.

Any order entrusted to us will be handled by capable, experienced men and will be treated in a conscientious, liberal manner. Should you not know just what varieties are best suited to your soil, locality and purpose, you can safely leave selections to us-we will see that you get best possible kinds.

We thank our many customers and friends for their past orders and patronage and we ask for a continuance of their trade in the future. We have received the highest commendation from our customers in Cuba, Mexico, Honolulu, Panama and other countries as well as this country that their stock was received in good condition and up-to-date in every respect, which goes to show that our stock is well grown and properly handled by good, careful and painstaking help.

To those who have never shared their trade with us, we ask you to give us a trial order and be convinced that you are making no mistake when you trade with us. We are sure we can please you. We are,
TURKEY CREEK NURSERIES, Macclenny, Fla.
C. F. BARBER, President, J. E. BARBER, Sec'y-Treas.

Yours very truly,

Shipping Points:

Macclenny, on S. A. L. Ry.

Nursery, on A. C. L. Ry.
Long Distance 'Phone in our office-call Macclenny.

Code address, "Barber, Macclenny, Fla."

Code used, A. B. C. Fifth Edition; American Ass'n of Nurserymen's. 


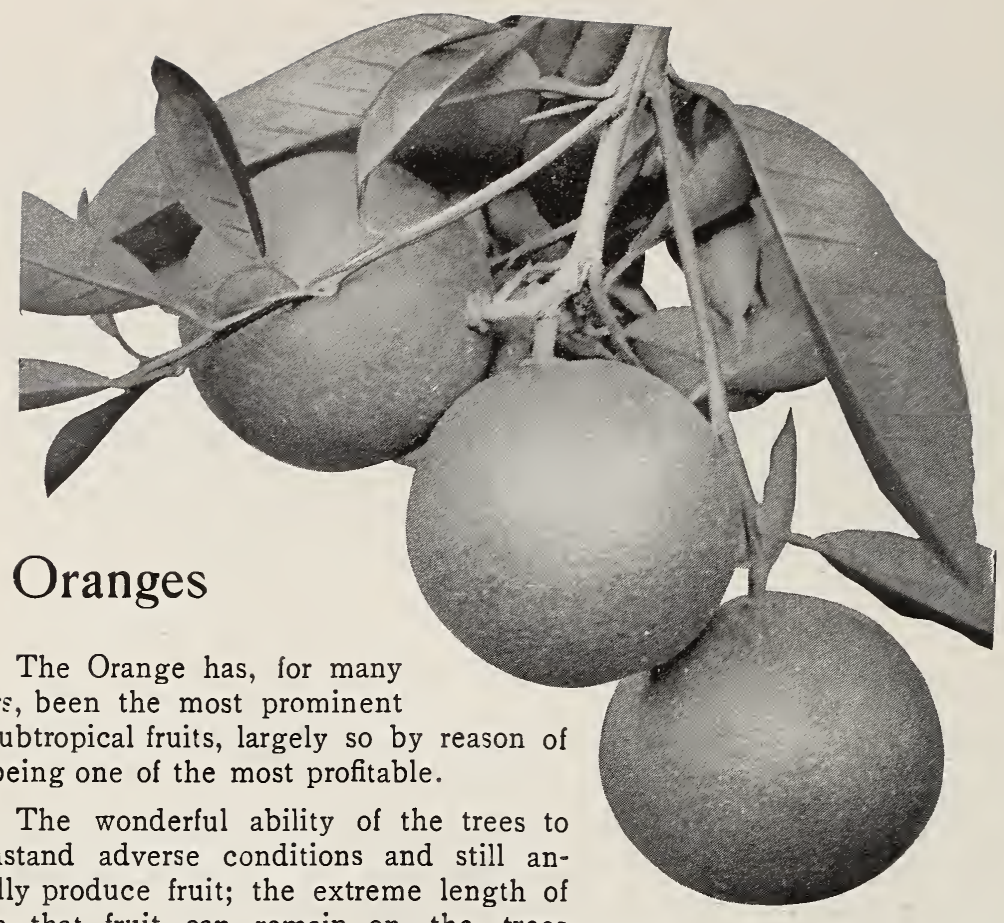

years, been the most prominent

of subtropical fruits, largely so by reason of its being one of the most profitable.

The wonderful ability of the trees to withstand adverse conditions and still annually produce fruit; the extreme length of time that fruit can remain on the trees after maturity, making it possible to ship when markets are in best shape; and the fact that if properly jacked the fruit will stand long distance shipment, makes the Orange one of the safest and most profitable fruits to grow.

In planting an orange grove it is poor business to try to get the cheapest trees possible. Cheap trees seldom prove healthy and fruitful. Orange nursery trees to prove vigorous and prolific should have large, well formed root systems and strong, clean, healthy tops one or two years old. Our trees are grown on loose sandy loam land, which permits the root systems to develop properly, and we give them everv care and plenty of fertilizer, which makes strong, vigorous tops. We have no White Fly on our place, and our trees are free from other insects and diseases. In other words we guarantee them to be strictly first class and true to name.

We have not attempted to grow all the known varieties, many of which are of but inferior quality. In our list will be found the most prominent and profitable kinds, such as can always be safely planted in either large commercial orchards or for home use.

We can furnish trees on Sour Orange or Citrus trifoliata stocks.

Those on Sour Orange are suitable for planting in almost all orange growing sections, preferring a fair to good qua!ity of soil, and a moist but not wet location. Generally preferred by planters and recommended by us unless some special local conditions make other stocks more desirable.

The Citrus trifoliata itself is entirely hardy in any of the Southern States, and oranges budded on it stand more cold than on other stocks. They should, however, be planted only on soils of good quality, preferably not loose sandy land. They require considerable moisture. All varieties are early and heavy bearers on Trifoliata. Recommended for North Florida, Southern Alabama, Mississippi, Louisiana, Texas and Northern Mexico.

Varieties and prices of Oranges on Sour stocks: Boone's Early, Centennial, Hart's Late, Homosassa, Jaffa, King, Madam Vinous, Majorca, Maltese Blood, Mediterranean 
Sweet, Parson Brown, Pineapple, Ruby, St. Michael's Blood, Tangerine, Washington Navel.

Grades
102 feet.

Boone's Early. Medium size; thin skin, but tough; quality good. Very early.

Centennial. Medium size; good appearance; quality good. Ripens mid-season and hangs on tree well.

Hart's Late. Medium size, round or slightly oval; smooth, solid and heavy; flesh very firm; quality good; few seeds. The tree is a very strong, spreading and vigorous grower, prolific; the foliage is distinct; few thorns. Ripens in April and hangs on tree in good condition until mid-summer. One of the latest varieties cultivated, and on this account one of the most profitable.

Homosassa. Size medium, round, slightly Gattened; very heavy; color bright; skin very smooth, thin; pulp fine, sweet and juicy; quality excellent; keeps and carries well. Tree vigorous and prolific

Jaffa. Medium size; pulp melting, scarcely any fiber; juicy, rich and of exquisite flavor.
In quality unsurpassed. Fruit hangs on tree in prime condition for a long period. A strong, upright grower of distinct habit, practically thornless; prolific bearer.

King. A very late variety of the Mandarin type; ripens March, April and May, and hangs on tree later. Size large, skin rough and loose, color deep orange red; flesh deep redorange; quality good; strong, upright grower; quite thorny.

Mediterranean Sweet. (S anford's.) Large size; fine appearance; rind smooth and tough. Quality good. Ripens late in season.

Parson Brown. Medium, round or slightly oblong; texture fine; quality good. Keeps and ships well. One of the best early varieties. Begins to ripen in October.

Pineapple. Size medium, round; skin very smooth and handsome; tough and dense; color light golden orange; quality excellent. One of

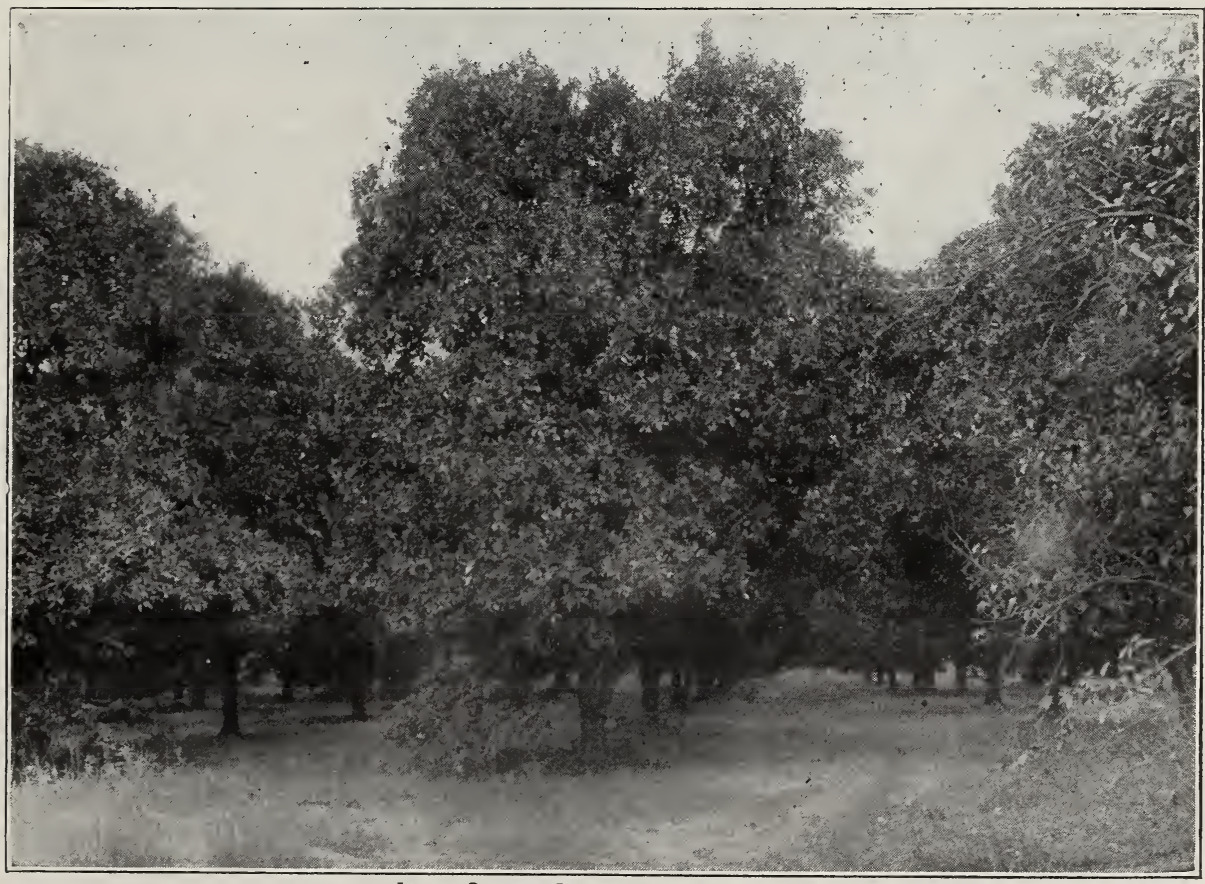

Large Orange Grove in South Florida 


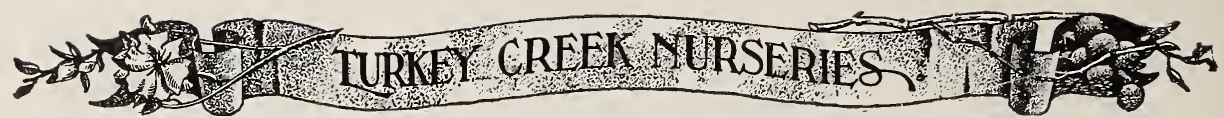

the best market varieties; ripens midseason. Tree a good grower and very prolific.

Ruby. Medium size, round; skin thin, but tough; pulp melting, rich, juicy and of fine flavor; quality excellent. After fully ripe becomes streaked or mottled with blood-red; often the entire pulp gets ruby-red, showing through the peel in a reddish blush on the outside. The best of the blood oranges. Tree is vigorous, nearly thornless and a heavy, regular bearer.

St. Michael's Blood. Fruit medium size, almost round, with thin but tough skin; pulp juicy, melting, rich, and of exquisite flavor, being unsurpassed in quality. Usually becomes mottled or streaked with blood-red after ripening, the pulp often a rich ruby-red, showing through the peel in reddish blush. Tree is a regular bearer, vigorous and nearly thornless.

Satsuma. (Synonyms: Oonshiu, Kii Seedless.) An extremely early variety of the Mandarin (Citrus nobilis) type; ripening in September, October and November. Fruit small to medium in size, flattened; rind light yellow, smooth and loosely adherent. Quality excellent. Nearly always brings a high price in market on account of its extreme earliness. Trees are rather smaller than other varieties, and more drooping in character of growth. The hardiest variety of edible orange known; has stood a temperature of 15 degrees above zero (Fh.) without injury. Can be grown successfully all along the Gulf Coast from Florida to Northern Mexico; in fact, bearing trees can be found in all of the Gulf States and are highly esteemed. Should be planted more in Texas and Mexico, as well as other Gulf States.

Tangerine. (Dancy's.) Probably the best known of the "Kid Glove" (Citrus nobilis) orange. Fruit medium to small; flattened. Skin very smooth and separates freely from flesh and segments separate easily. Color of

Varieties and prices of Oranges on Citrus trifoliata stock: Centennial, Hart's Late, King, Majorca, Maltese Blood, Parson Brown, Pineapple, Ruby, Satsuma, Tangerine, Washington Navel.

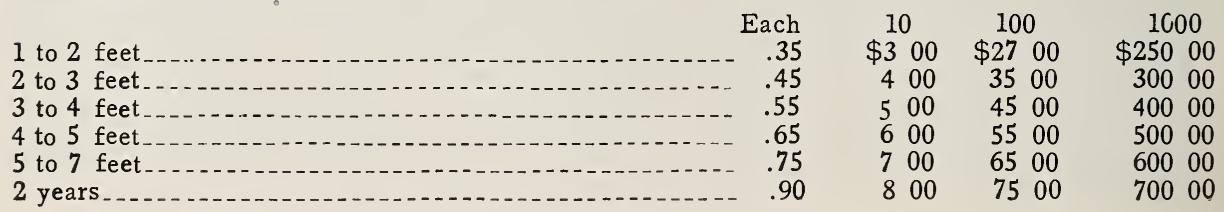




\section{Pomelos (Grape Fruit)}

Scarcely second to the Orange in commercial importance is the Pomelo. In fact, for a number of years Grape Fruit has netted much larger returns, and from present indications, this fruit will grow in popularity in the markets. To any one planting an orchard of Citrus trees, we should strongly recommend at ieast one-third to onehalf of the trees to be Grape Fruit.

The varieties we list are mostly well-known as amongst the very best, while all of them are good reliable kinds.

Common. One of the fine old fashioned grape fruit so much in demand. Large size, fine appearance and excellent quality. Heavy bearer and good shipper.

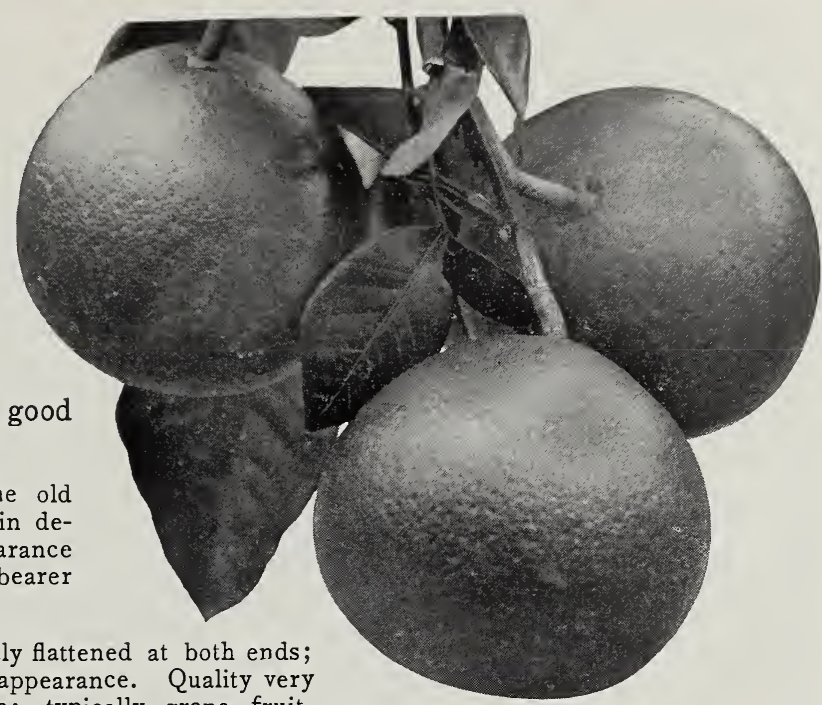

Duncan. Large size, slightly flattened at both ends; skin very smooth and of fine appearance. Quality very best; flavor exceptionally fine; typically grape fruit. Strong grower and heavy bearer. One of the best.

Everett. Large size, smooth skin. Quality good. Heavy bearer. Good shipper.

Excelsior. Medium to large, smooth skin. Very juicy, and of genuine bitter grape fruit flavor. Hangs on tree late in season. Good grower and produces abundantly in large bunches.

Josselyn. Medium to large, roundish; dark yellow; rind smooth. Quality excellent; heavy bearer and a good shipper. Late ripener.

Marsh. (Seedless.) Large size, slightly flattened; skin smooth. Quality fine. Nominally seedless, it usually has six or eight seeds. Good grower, heavy bearer, and good keeper. One of the best.

Pernambuco. Medium to large, nearly round.
Skin smooth. Quality excellent; quite free from bitter; can be eaten out of hand. Good grower and bearer. Ripens late and holds on trees well.

Silver Cluster. (Hall's.) Large to very large, roundish; skin smooth, rather darker than most varieties; quality first-class; bitter characteristic strongly marked. Bears in clusters, as name indicates. Heavy bearer and excellent variety.

Triumph. Small to medium, skin smooth and usually very bright. A heavy regular bearer. Quality good, very little bitter.

Walters. Medium size, skin smooth and of light lemon color. Quality excellent. Bears in large bunches. Strong grower and heavy bearer. Quite a favorite in many sections.

Varieties and prices of Pomelos on Sour and Grape Fruit stocks: Common, Duncan, Everett, Excelsior, Josselyn, Mar: h, Pernambuco, Silver Cluster, Triumph, Waiters.

Grades

\section{Each}

1 to 2 feet

2 to 3 feet

3 to 4 feet

4 to 5 feet

5 to 7 feet

\begin{tabular}{rrr}
10 & \multicolumn{1}{c}{100} \\
$\$ 300$ & $\$ 2500$ \\
400 & 3500 \\
500 & 4500 \\
650 & 6000 \\
7 & 50 & 7000
\end{tabular}

1000

$\$ 20000$

32000

42000

55000

65000 


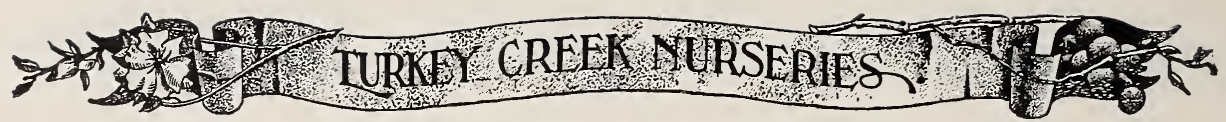

Varieties and prices of Pomelos on Citrus trifoliata stocks: Marsh, Duncan.

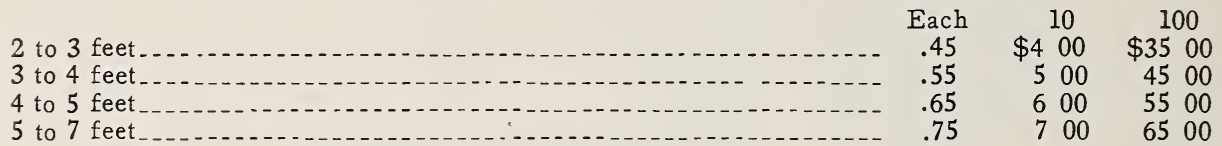

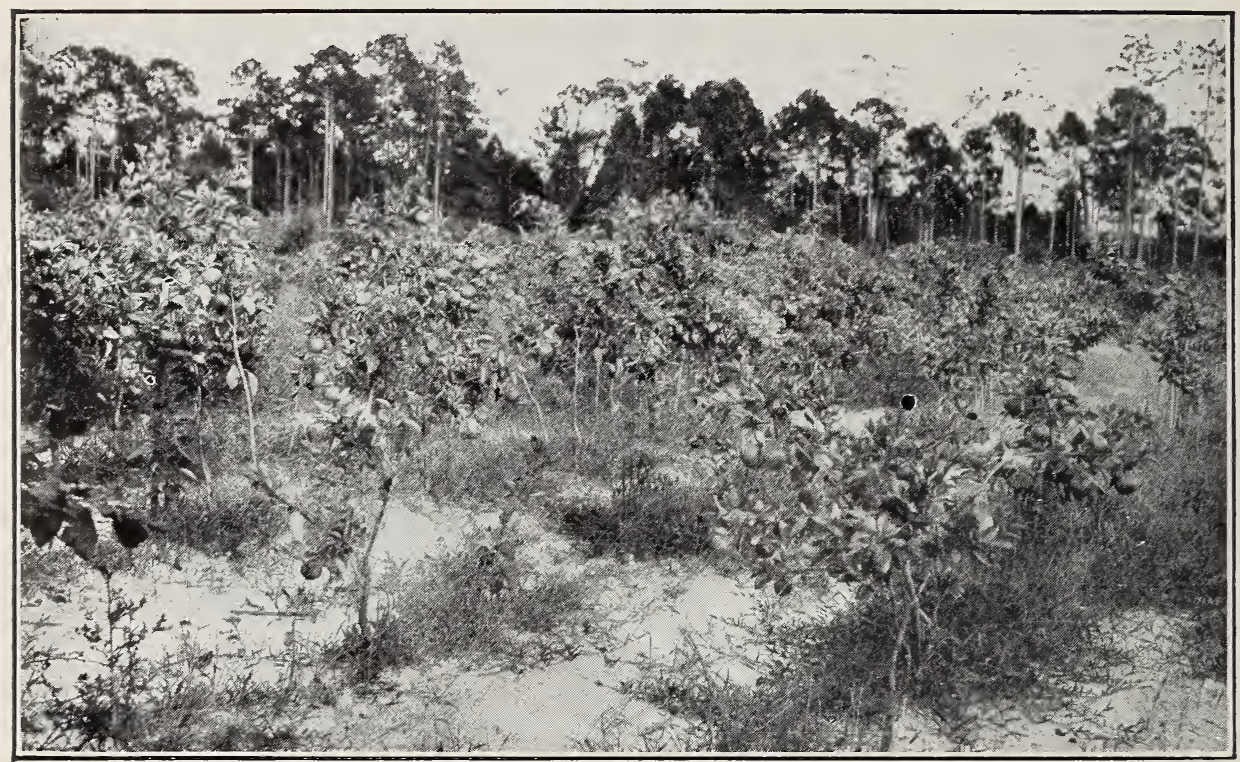

Grape Fruit bearing in Nursery Rows

\section{Lemons}

In tropical Florida, in the West Indies, Mexico, and Central America, as well as in Southern California, lemons can be successfully grown commercially, and if budded on the hardy Citrus trifoliata stock, they can be grown all along the Gulf Coast, at least for home use. We can furnish them on Sour Orange and C. trifoliata stocks:

Villa Franca. Medium size, smooth, thin rind; very juicy, acid very strong and of fine quality. Tree a vigorous grower and prolific bearer. One of the prominent market kinds, and considered one of the best. Extremely hardy, stands nearly as much cold as ordinary sweet oranges.
Ponderosa. Extremely large, fruit weighs from 20 to 36 ozs. Very juicy, acid strong and of excellent flavor; genuine lemon taste. Rind thin for such large fruits. Tree good grower and bears very young and heavily. Quite unique and valuable.

Prices of L $\leqslant$ mons on Sour Orange stocks:

Grades
1 to 2 feet_...




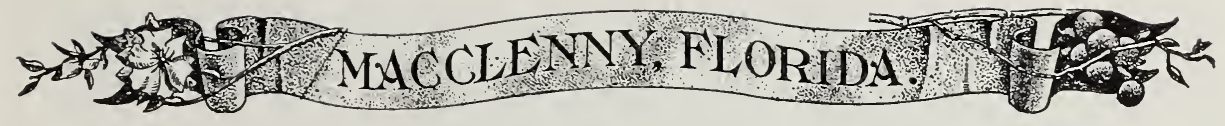

Prices on Ponderosa and Villa Franca Lemons on Citrus trifoliata stock:

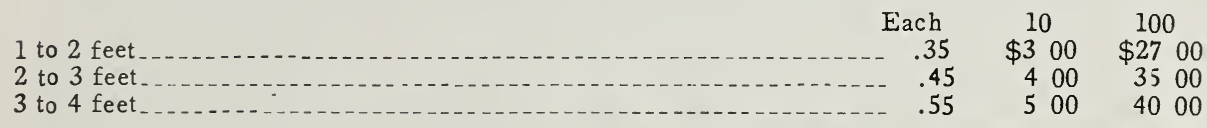

\section{Kumquats}

A very unique little tree, producing miniature fruits resembling small oranges. Very ornamental in appearance, particularly when loaded with the golden yellow fruits, during fall and winter. The trees bear as soon as they have sufficient hard wood to produce fruit; not infrequently the first year in nursery rows. The fruit is edible, rind and all being eaten, but is used largely for table decoration and preserving and crystallizing. When shipped to Northern markets properly (little bunches

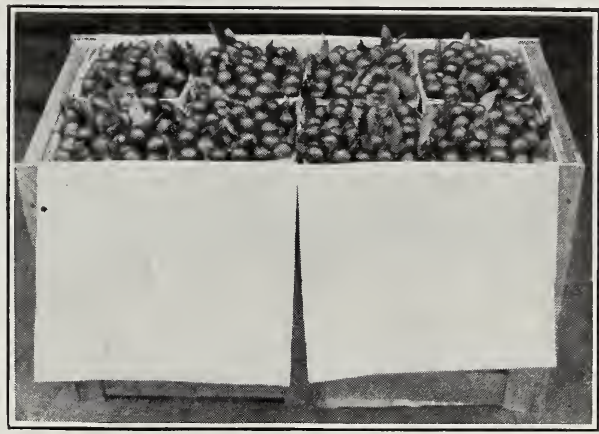

Kumquats packed for shipment-they generally bring fancy prices with leaves being packed in strawberry carrier crates), the fruit nearly always brings fancy prices, often as much as $\$ 6.00$ to $\$ 10.00$ per crate of 32 quarts. We have trees on Citrus trifoliata stocks, and can furnish both varieties: Marumi (round), fruit about an inch in diameter. Nagami (oblong), about an inch and a half long and an inch in diameter.

Prices on Kumquats on Citrus trifoliata stock.

\begin{tabular}{|c|c|c|c|}
\hline $\begin{array}{l}\text { year, } 12 \text { to } 18 \mathrm{in} \text {, Small Grade } \\
\text { year, } 1 \mathrm{1} / 2 \text { to } 2 \mathrm{ft} \text {, Medium Grade } \\
\text { year, } 2 \text { to } 3 \mathrm{ft} \text {, Standard Grade } \\
\text { and } 2 \text { years, } 3 \text { to } 5 \text { feet }\end{array}$ & $\begin{array}{r}\text { Each } \\
-\quad .35 \\
-\quad .40 \\
-\quad .60 \\
-100\end{array}$ & $\begin{array}{rl}10 & 10 \\
3 & 00 \\
3 & 50 \\
5 & 00 \\
8 & 00\end{array}$ & $\begin{array}{r}100 \\
\$ 2500 \\
3000 \\
4500 \\
7500\end{array}$ \\
\hline
\end{tabular}

\section{Peaches}

For several years the demand for peach trees has been much heavier than the supply. This season we have a fine lot of trees, including nearly all of the best Southern varieties; but the demand is still very heavy and it is advisable to place orders early to make sure of kinds and sizes wanted.

Explanation of list: The first column shows type to which the variety belongsthus, "Sp." means native Spanish; "Per." means Persian race; "N. C.," Northern Chinese; "Hon.," Honey; "P-to," Peen-to; "O B.," Oriental Blood. The second column gives the time of ripening, represented by initials: V. E, E., M., L, meaning very early, early, medium and late. The other columns represent different sections of the country, as follows:

"A" representing South Florida and other tropical sections.

" $B$ " representing Eastern North Florida.

"C" representing Western North Florida, Lower Georgia, Alabama and Mississippi.

"D" representing Coastwise Texas and Louisiana.

" $E$ " representing other peach-growing sections of the United States.

The starring in each column represents adaptability; that is, three stars (***) means that variety is well adapted to that section and is highly recommended; two stars (**) means adapted and recommended, but not so highly as when marked with three stars; 


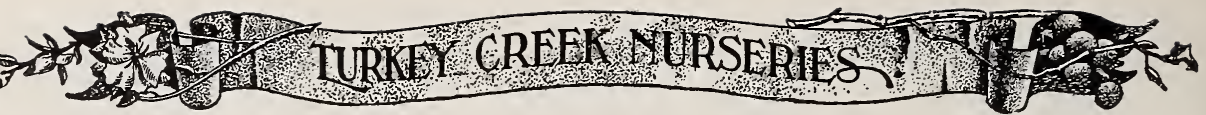

one star $\left(^{*}\right)$ means that the variety does only fairly well in that section; while no staring means variety is not recommended for that section.

\begin{tabular}{|c|c|c|c|c|c|c|c|}
\hline VARIETIES & TYPE & RIPENS & A & B & $\mathrm{C}$ & D & $\mathrm{E}$ \\
\hline Angel - & P-to & E. & $* * *$ & $* * *$ & * & * & \\
\hline idwell's Early & P-to & V. E. & $* * *$ & $* * *$ & & & \\
\hline Bidwell's Late. & P-to & E. & ** & $* *$ & & & \\
\hline Cabler's Indian & Sp. & M. & * & $* *$ & $* *$ & $* *$ & $*$ \\
\hline Carman...... & N. C. & E. & & & $* * *$ & $* * *$ & $* * *$ \\
\hline Climax & Hon. & E. & $*$ & $* *$ & $* *$ & $* *$ & * \\
\hline Colon & Hon. & E. & ** & $* * *$ & ** & $*$ & \\
\hline Countess & Sp. & M. & --- & - & $* *$ & $*$ & $\stackrel{*}{*}$ \\
\hline Crawford's Early. & Per. & E. & $\cdots$ & ---- & $*$ & * & $* * *$ \\
\hline $\begin{array}{l}\text { Crawford's Late-- } \\
\text { Dorothy N }\end{array}$ & $\begin{array}{l}\text { Per. } \\
\text { P-to }\end{array}$ & M. & **- & ***-1 & $\begin{array}{l}* \\
*\end{array}$ & * & $* *$ \\
\hline Elberta & N. C. & $\mathrm{M}$. & & & $* * *$ & $* * *$ & $* * *$ \\
\hline Estella_..... & Sp. & L. & $*$ & ** & ** & ** & \\
\hline Everbearing ... & Sp. & E. - L. & * & $\begin{array}{c}* \\
* *\end{array}$ & $\begin{array}{l}* \\
* *\end{array}$ & * & * \\
\hline Florida Crawford & $\begin{array}{l}\text { Hon. } \\
\text { Sp. }\end{array}$ & $\begin{array}{l}\text { M. } \\
\text { M. }\end{array}$ & $*$ & $* *$ & $* *$ & * & \\
\hline Florida Gem & Hon. & E. & ** & $* * *$ & ** & $* *$ & \\
\hline ctober & Sp. & L. & * & ** & ** & $* *$ & --- \\
\hline Goodbread's Late & Sp. & L. & * & $* *$ & ** & $* *$ & \\
\hline-1 & Per. & V. E. & & & $* * *$ & $* * *$ & 卷* \\
\hline ellow & P-to & E. & ** & ** & & & \\
\hline $\mathrm{Ho}$ & Hon. & E. & $*$ & ** & *** & $* *$ & \\
\hline & Hon. & $\mathrm{E}$. & $*$ & $* *$ & $* *$ & ** & \\
\hline & P-to & V. E. & $* * *$ & *** & $* * *$ & ** & \\
\hline & P-to & V. E. & $* * *$ & $* *$ & ** & $*$ & \\
\hline $\mathrm{Ov}$ & Hon. & E. & $*$ & $* *$ & * & * & $-\beta$ \\
\hline & Hon. & E. & $*$ & ** & $* * *$ & ** & \\
\hline Peen-to & P-to & V. E. & $* * *$ & $* *$ & * & & --- \\
\hline Powers' September & Sp. & L. & $\begin{array}{l}* \\
*\end{array}$ & $\begin{array}{l}* * \\
* *\end{array}$ & $\begin{array}{l}* * \\
* *\end{array}$ & $\begin{array}{l}* * \\
* *\end{array}$ & \\
\hline $\begin{array}{l}\text { Sangmel } \\
\text { Sneed }\end{array}$ & $\begin{array}{l}\text { Hon. } \\
\text { N. C. }\end{array}$ & $\begin{array}{l}\text { E. } \\
\text { V. E. }\end{array}$ & * & $* *$ & $\begin{array}{l}* * * \\
* * *\end{array}$ & $* * *$ & $* * *$ \\
\hline Suber & P-to & V. E. & $* * *$ & $* * *$ & $* *$ & $* *$ & $\cdots$ \\
\hline Taber .. & Hon. & E. & $*$ & $* * *$ & ** & $* * *$ & \\
\hline Triana & Hon. & $\bar{E}$. & $* * *$ & *** & 并 & $* *$ & \\
\hline & Per. & V. E. & & & ** & $* * *$ & $* * *$ \\
\hline Waldo & P-to & V. E. & *** & $* * *$ & ** & $* *$ & -- \\
\hline Yum Yum & $P$-to & V.E. & *** & ** & ** & $* *$ & \\
\hline
\end{tabular}

PRICES ON PEACHES.

\begin{tabular}{|c|c|c|c|c|}
\hline & Each & 10 & 100 & 1000 \\
\hline 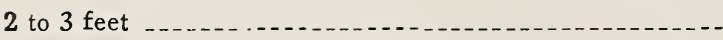 & .12 & $\$ 100$ & $\$ 800$ & $\$ 6500$ \\
\hline 3 to 4 feet & .15 & 120 & 1000 & 8000 \\
\hline 4 to 6 feet & .20 & 150 & 1200 & 10000 \\
\hline 6 feet up.-...- & .30 & 250 & 1800 & \\
\hline
\end{tabular}

Angel. Medium to large; highly colored, especially on sunny side; flesh white, melting, juicy, sub-acid, fine flavored; entirely devoid of the bitter noyau flavor of most Peen-to varieties. Ripens June 20 to 30 . Blooms a month later than Peen-to, consequently is seldom caught by frosts. Valuable market kind.

Bidwell's Early. Medium to large; roundish oblong, with short recurved point; color creamy white, beautifully washed with carmine; flesh greenish white, fine grained, melting, juicy and sweet; slight noyau flavor. Clingstone. Commences ripening with Peen-to, but continues longer. Valuable market kind in South Florida and other tropical sections.

Bidwell's Late. Medium to large, nearly round; yellowish white; flesh fine grained, juicy and sweet. Quality excellent; slight noyau flavor. Cling. Ripens about three weeks later than Peen-to. 


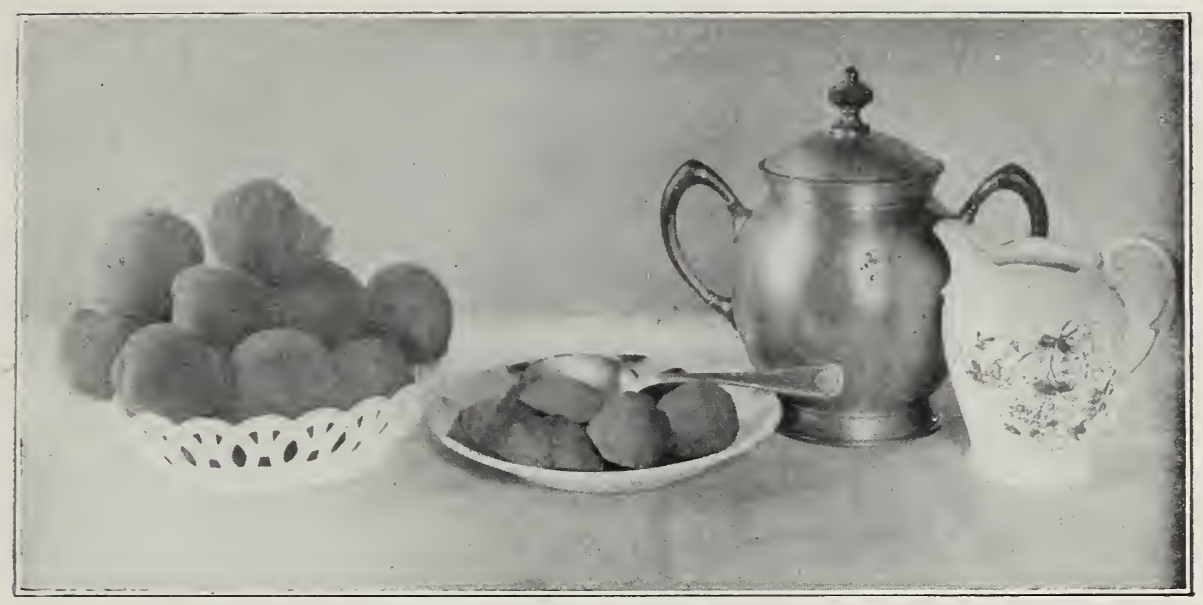

Peaches and Cream

Cabler's Indian. Origin, Texas; closely resembles Flewellen. Purple flesh, containing deeper purple veins, rich, subacid; decided Indian type; clingstone, very fine. Ripens July 15 to 25 .

Carman. Large size: resembling Elberta in shape; skin creamy white or pale yellow, with deep blush; flesh tender and of fine flavor, juicy, freestone. Prolific. June 10 to 20.

Carrie Rowe. A large native white cling, excellent for home use, or nearby markets. Fine for preserving. Ripens July 10 to 20 .

Climax. Size medium, round, slightly oblong, with recurved point; color pale yellow, washed with red; flesh yellowish white, fine grained, melting, sweet and sprightly; quality excellent: freestone. June 25 to July 5.

Colon. Medium to large; roundish oblong; skin creamy white washed with red; flesh white streaked with red, particularly around the pit, sometimes almost blood-red; juicy, subacid, delicious; freestone. June 15 to 25.

Crawford's Early. Large; yellow, with red cheek; flesh yellow, juicy and rich; free. End of June.

Crawford's Late. Large; skin yellow, with red cheek; flesh yellow, fine quality: free. Last of July.

Dorothy N. Seedling of Angel, originated in Lake County, Fla. Large size, nearly round; remarkably handsome; flesh yellow, rich, subacid, fine flavor. Ripens July 5 to July 15. A fine mid-season variety for Central and South Florida.

Elberta. Very large: skin yellow washed with red; flesh yellow, firm and juicy; highly flavored; free. Probably planted to a larger extent commercially than any other variety; one of the most profitable market kinds where adapted.
Does well in West Florida and sections further west and north, but is not adapted to peachgrowing sections of Florida or further south.

Estella. Large size, almost round; skin greenish yellow with red cheek; flesh yellow, quality excellent; free. One of the finest extremely late varieties. Ripens September I to 10 .

Everbearing. Medium to large; creamy white, streaked and mottled with purple; flesh white with red veins; juicy, subacid, quality good; freestone. Commences ripening about July 1 and produces successive crops until last of August.

Fannie Rowe. Very large yellow cling, overspread with brilliant red. Ripens July 10 to 20. A fine peach for home use, or nearby markets. Excellent for preserving.

Ferdinand. Large, smooth, roundish oblong, somewhat pointed; skin white, overspread, with red; flesh white, veined with red; meaty, rich and delicious. Cling. June 25 to July 5 .

Florida Crawford. Large, roundish oblong; shallow but distinct suture; light yellow with red cheek; flesh yellow, melting, juicy, rich flavor; quality excellent; free. July 15 to 25 .

Florida Gem. Large, roundish oblong, pointed; light yellow, overlaid with deep red on sunny side; flesh juicy, sweet and rich, red at pit; quality excellent; free. July 1 to 10. A good market variety.

Gibbon's October. Medium to large; skin creamy white; flesh white; quality good. Free. September 25 to October 15. A fine, extremely late variety.

Goodbread's Late. Very large, white, cling, with red cheek. Ripens August 5 to 15 . A native of Columbia County; a very valuable variety for all purposes. 


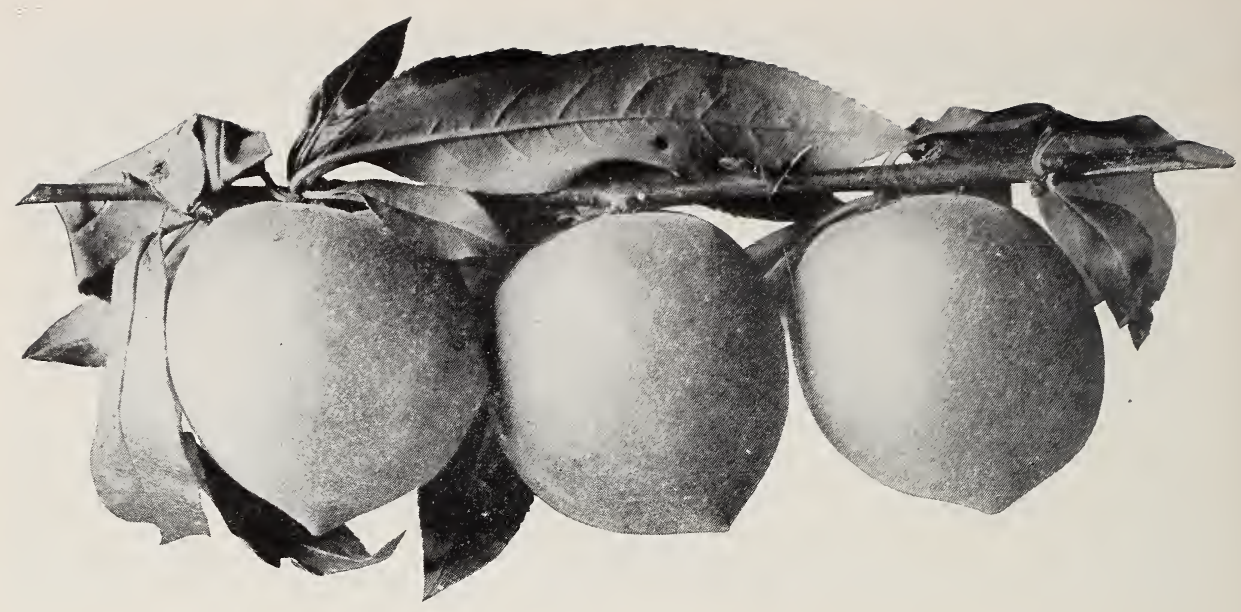

Greensboro. Large; light yellow, beauti fully washed and streaked with bright red; a delicate clean color; flesh white, very juicy and of fine flavor; quality excellent. Semi-cling. About June 1.

Hall's Yellow. Seedling of the Angel, originated by Mr. R. E. Hall, of Volusia County, Fla., and sometimes called the Bor1anza Peach. Medium to large size, nearly covered with red; flesh deep yellow, red at the pit; firm, quality fair, subacid flavor; keeps well and ships well. June 20 to July 5 .

Honey. Medium, oval; deep suture nearly full length, terminating in a long, sharp, peculiar, re-curved point; creamy white with deep red on sunny side; flesh creamy white, fine, juicy, melting, very sweet, rich flavor; quality excellent; free. June 5 to 20 .

Imperial. Large to very large; oblong, pointed, with ridge on one side; skin greenish yellow washed with red; flesh white, juicy, sweet, excellent; free. June 25 to July 5.

Jewel. The most popular market peach in Florida. Fruit medium to large; roundish oblong; highly colored deep red cheek; Hesh yellowish white, red at stone; very juicy, sweet, melting and delicious. Quality best. Ripens ten days to a fortnight ahead of Waldo or Peento. While it produces well, it does not overbear like Waldo. Good shipper. Freestone. Tree vigorous and clean, healthy grower. Very valuable.

Maggie. Medium, roundish oblong, yellowish white, washed with red; flesh juicy, sweet, melting, semi-cling. Ripens with Peen-to. Quite similar in appearance and general description to Bidwell's Early.

Mayflower. Large; well colored; red all over; of fine quality; cling. A very promising variety. Its earliness, high color and excellent quality are strong points in its favor. Ripens four or five days earlier than Sneed.
Oviedo. Seedling of Honey. Medium size, roundish oblong with short re-curved point; greenish yellow washed with red; flesh white streaked with red; firm, good flavor; free. Early July.

Pallas. Medium to large, roundish; deep red, splashed with light and deep yellow; flesh white, rich, vinous, melting; quality excellent; free. June 20 to 30 . Well adapted all along the Gulf Coast from Florida to Texas.

Peen-to. A peculiarly formed peach, like a flat turnip, both ends depressed; pit same shape. Color greenish white washed with red on sunny side; when allowed to ripen on tree changes to delicate waxen yellow. Flesh greenish white, sweet, rich, very juicy and fine $\mathrm{fla}$ vored; slight noyau tang; cling. May 20 to June 1.

Powers' September. A very late variety of medium size and good quality; flesh white; free. September 1 to 15 .

Sallie Rowe. A fine native peach; very large, nearly round; flesh yellow. Clingstone. Ripens July 10 to 20 . A good variety for preserving, or other home use, or for home markets.

Sneed. Medium size, slightly oval; creamy white with deep blush on sunny side; flesh white, juicy and finely flavored; semi-cling. A week to ten days earlier than Alexander.

Suber. Medium to large, roundish oblong, with short, re-curved point; skin creamy white, washed with carmine; flesh fine grained, melting, juicy and sweet, with slight noyau flavor; cling. May 20 to June 1. Very similar to Bidwell's Early; a little larger and a trifle more acid. A valuable market variety, much in favor among Volusia County orchardists.

Taber. Medium to large; roundish oblong; creamy white washed with red; flesh white with red around pit; firm, juicy, sweet, highly flavored; cling. A fine peach for canning as well as for eating out of hand. 


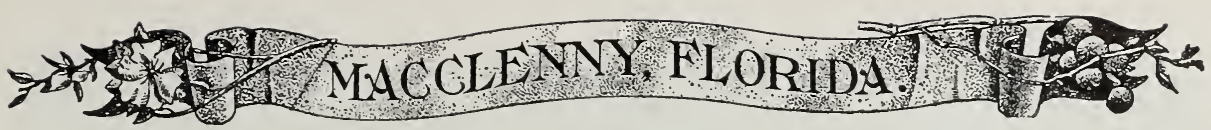

Taylor. Very large fine cling peach; beautiful reddish cheek on sunny side; flesh white, except red around pit. Quality excellent. A good grower and heavy bearer. Excellent for preserving. Ripens early.

Triana. One of the finest of the Honey seedlings. Fruit medium size, roundish oblong, pointed; skin creamy white, overspread with red; flesh white with red around pit, rich, juicy, very sweet and highly flavored; quality best: freestone. June 25 to July 5 .

Triumph. Large size, nearly round; yellow, nearly covered with dark red; flesh bright yellow, quality good; pit small; semi-cling. Ripens with Alexander; blooms late.

Waldo. Medium size, roundish oblong; creamy white, with deep red cheek; very handsome; flesh white, red at pit, juicy, melting, sweet and delicious. Free. May 20 to June 1. Seedling of Peen-to crossed with Honey. It has the delightful flavor of both parents without the bitter tang of the Peento. One of the best and most reliable market kinds for Florida and other semi-tropical sections. A heavy bearer. Succeeds well all along the Gulf Coast and in the West Indies and Mexico.

Yum-Yum. Size medium, roundish oblong; skin yellowish white, marked with carmine; flesh fine-grained, sweet, juicy and melting; sub-cling. Ripens about with the Peen-to. Very much like Bidwell's Early in appearance, the time of ripening and other qualities.

\section{Plums}

The pure Japanese type of Plums does well in many sections of the United States and has been planted quite extensively commercially; but all along the Gulf Coast country they are a little out of their range and do not always bear satisfactorily. There are, however, now several cross-bred varieties (Japanese and Southern Chickasaw types crossed) which bear well in all the Gulf Coast section and even in South Florida. Of these cross-bred varieties Excelsior, Terrell, Florida Queen, Howe and Miller are some of the best. We can heartily recommend them for either home use or commercial planting

PRICES OF PLUMS ON MARIANNA STOCK.

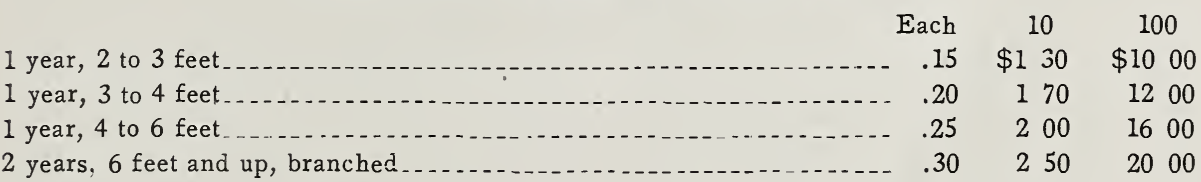

Abundance. Medium to large; roundish, pointed; greenish yellow overlaid with dull purplish carmine; flesh light greenish yellow; sweet and juicy, slight subacid and apricot flavor; small stone; cling; quality excellent.

Babcock. (Botankio.) Fruit large, round, conical; skin yellow, overlaid rather thickly with purplish red and blue bloom; flesh deep orange; solid, sugary, subacid, good flavor and quality; cling. Tree vigorous and prolific.

Burbank. Medium to large, from 5 to $5 \mathrm{x} / 2$ inches in circumference; very uniform in size; nearly round; cherry red, often dotted yellow or marbled with lilac bloom; flesh firm and meaty, deep yellow, rich and sweet and highly flavored; cling. Strong grower and bears rather farther south than most of the Japanese strain. A very popular variety.

Chase. (Yellow Japan.) Fruit large, round, verging to heart-shaped; under-color yellow, overlaid with dull red and showing many golden dots, finally becoming dull red all over; bloom thick; flesh yellow, firm and rather juicy, sweet and good. A very excellent plum. The tree is a strong, upright, spreading grower, and productive. Middle of July

Excelsior. A cross-bred variety which has proven its value in nearly all sections of the South and particularly in Florida, even as far south as Tampa. Size medium to large, about $1 \mathrm{r} / 2$ inches in diameter; round; reddish purple with heavy blue bloom; very handsome; flesh juicy, melting, sweet and of excellent quality; cling. Very early, about June 1.

Florida Queen. A new variety, originated by Mr. Henry Reed, of Baker County, Florida. Supposed to be a cross between the old Florida native and the Kelsey, of which it is a seedling. Fruit of excellent quality; large, yellow, $11 / 2$ to 2 inches in diameter; melting when ripe. Be- 


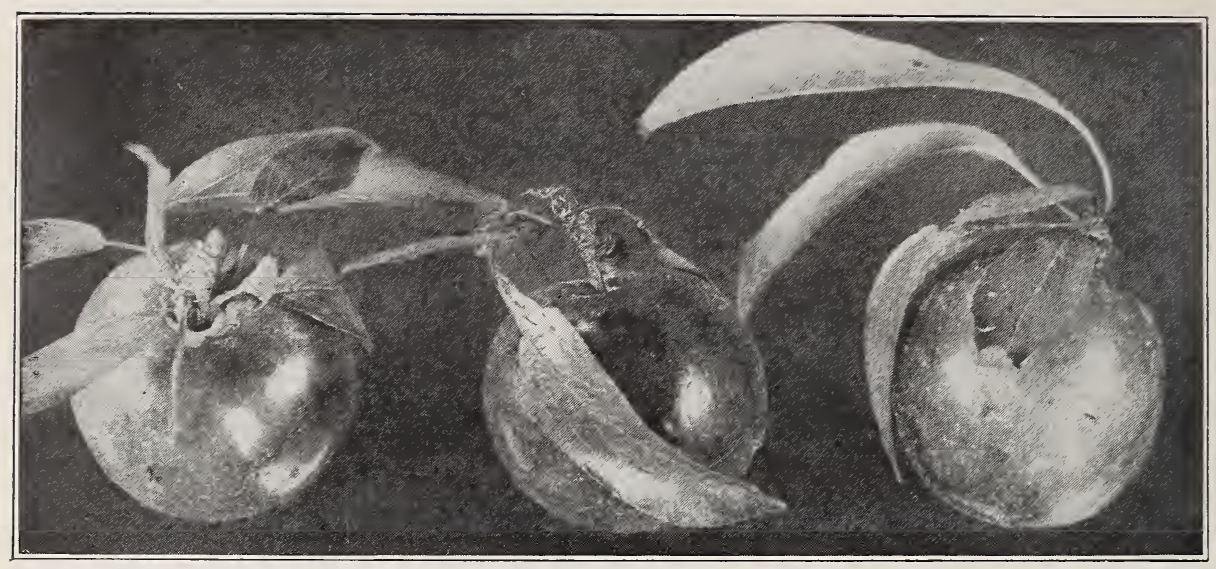

Excelsior Plum

A good bearer in Florida and all along the Gulf Coast country

gins to ripen the 15th of July and lasts till the 15th of August. Can be gathered when beginning to ripen, and will keep from four to five days in perfectly good condition. One of the best for Florida orchards. Very prolific.

Hale. Handsome, large, round-cordate; orange, thinly overlaid with mottled red, so as to have a yellowish red appearance, or, wellcolored specimens, deep cherry-red with yellow specks; flesh yellow, soft and juicy (yet a good keeper) with a very delicious slightly acid peach flavor; skin somewhat sour; cling. Very late. Tree a remarkably strong grower.

Howe. (A cross between the Japanese and native varieties.) Originated in Putnam County, Florida. Bears heavy annual crops of medium to large size plums, ripening early in May. This plum has the hardiness of our native fruit combined with size and flavor of the Japan varieties. Color, a rich, dark red overspread with bluish purple bloom; flesh is firm, rich and juicy. A plum that can be depended upon to give you a crop when others fail.

Miller. One of the cross-bred plums like Excelsior and Terrell. About the size of Excelsior; quality excellent; color light greenish yellow. Ripens in July.

Ogon. Fruit medium to large, round or slightly flattened; suture prominent. Skin bright yellow, with a light creamy bloom, giving the fruit a whitish appearance. Flesh thick and very meaty, but not juicy. Firm and long keeping; good, but not of the best quality. Free.

Pissard. (Prunus Pissardii.) This variety is used principally as an ornamental; its vivid purple foliage, which retains its color throughout the summer, is strikingly handsome and adds a touch of color.

Red June. (Red Nagate.) Medium to large; cordate and long pointed; suture deep, lopsided. Deep red with handsome bloom: very showy; flesh light yellow, firm, slightly subacid to sweetish; quality good; semi-cling.

Satsuma Blood. Fruit medium to large, broadly conical, with a blunt, short point. Suture very deep. Skin very dark and dull all over. Firm, very juicy, quality good. Free. Flesh firm and solid, deep blood-red. It is excellent for preserving. It succeeds in many sections and does fairly well in Florida.

Terrell. A new cross-bred variety, supposed to be a seedling of Excelsior, and very similar in character of growth to that variety. Fruit larger than Excelsior, $11 / 2$ to 2 inches diameter, and of finer flavor; color reddish crimson, somewhat mottled and covered with purplish bloom; wine red when fully ripe; flesh greenish yellow, meaty, sweet, with sufficient acidity to give a fine tone; cling. June 10 to 15 . We recommend this very strongly.

Wickson. Very large, long cordate or oblong pointed; deep maroon-red; flesh firm, yellow, sweet and highly flavored; cling. One of the best of the Japanese type.

\section{Pears}

Only Pears of criental strain do well in the South, but these are at home here and succeed admirably. The three best varieties are LeConte, Kieffer and Garber. LeConte is an early kind and nearly always brings good prices in Northern markets. Kieffer ripens late in the season and holds on trees remarkably well; it is one of the finest for cooking. Our trees are grown on Japan and French pear stocks, and are exceptionally fine. 


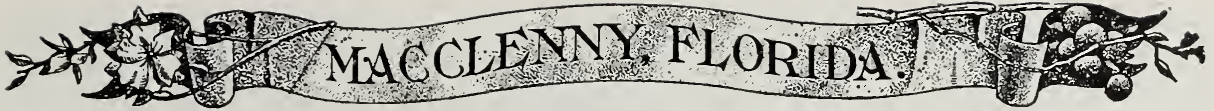

\section{PRICES ON PEARS.}

2 to 3 feet
3 to 4 feet
4 to 6 feet $\ldots$ Each

Garber. Similar in size, shape and general appearance to Kieffer, but tree more spreading. Ripens ahead of Kieffer

Kieffer. Very large, pyriform in shape. Color light greenish yellow with bright red cheek; quite handsome. Extremely prolific, apt to overbear, especially when young. Valuable for market or culinary purposes.

LeConte. Large to very large; pyriform; smooth, !'ght yellow when ripe. Early July. Quality excellent when properly ripened; that is when picked before fully ripe and placed in bulk, preferably in a dark

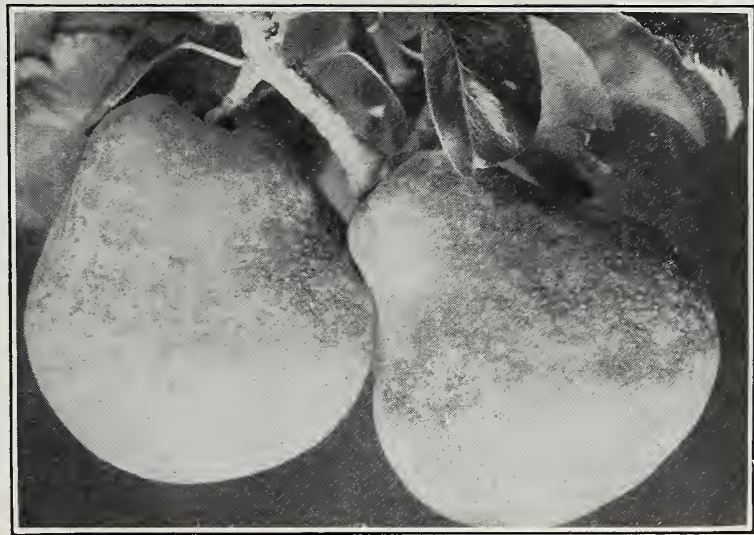

Kieffer Pears

room. When shipped the barrels answer the same purpose. Ships well. Very prolific. Adapts itself to a great number of soils and locations.

\section{Japan Persimmons}

Japanese Persimmons are well adapted to the Cotton Belt of the South They are easily grown, have but few insect enemies, and are heavy annual bearers. The fruit is very large, handsome and luscious and if properly marketed, generally bring fancy prices.

We have an especially fine lot of trees this season, including all the most prominent varieties. Plant a small orchard; we are sure it will pay you.

PRICES ON PERSIMMONS.

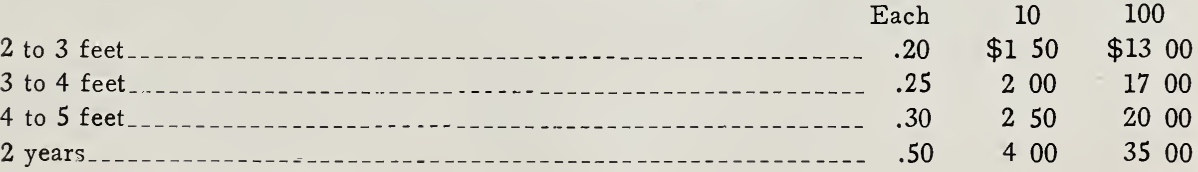

Costata. Size medium, conical, pointed, slightly four-sided; skin salmon-yellow: flesh light yellow: occasionally a few seeds and dark flesh around them. Astringent until ripe, then good. Very late A good keeper. A rapid grower, upright; the most ornamental of all varieties.

Hachiya. The largest of all; about $33 / 4$ by $31 / 4$ inches; oblong conical, with short point. Brilliant dark red, sometimes with dark spots and rings at blossom end; very showy. Flesh deep yellow, with occasional dark streaks and seeds. Astringent until ripe, then very delicious.

Hyakume. Large to very large; about $23 / 4$ by $3 \mathrm{r} / 8$ inches; generally roundish oblong, nearly always slightly flattened at both ends and often depressed at blossom end. Light buffish yellow; very apt to be marked with rings and veins at blossom end. Flesh dark brown, crisp, meaty, sweet. Not astringent, good while still hard. 


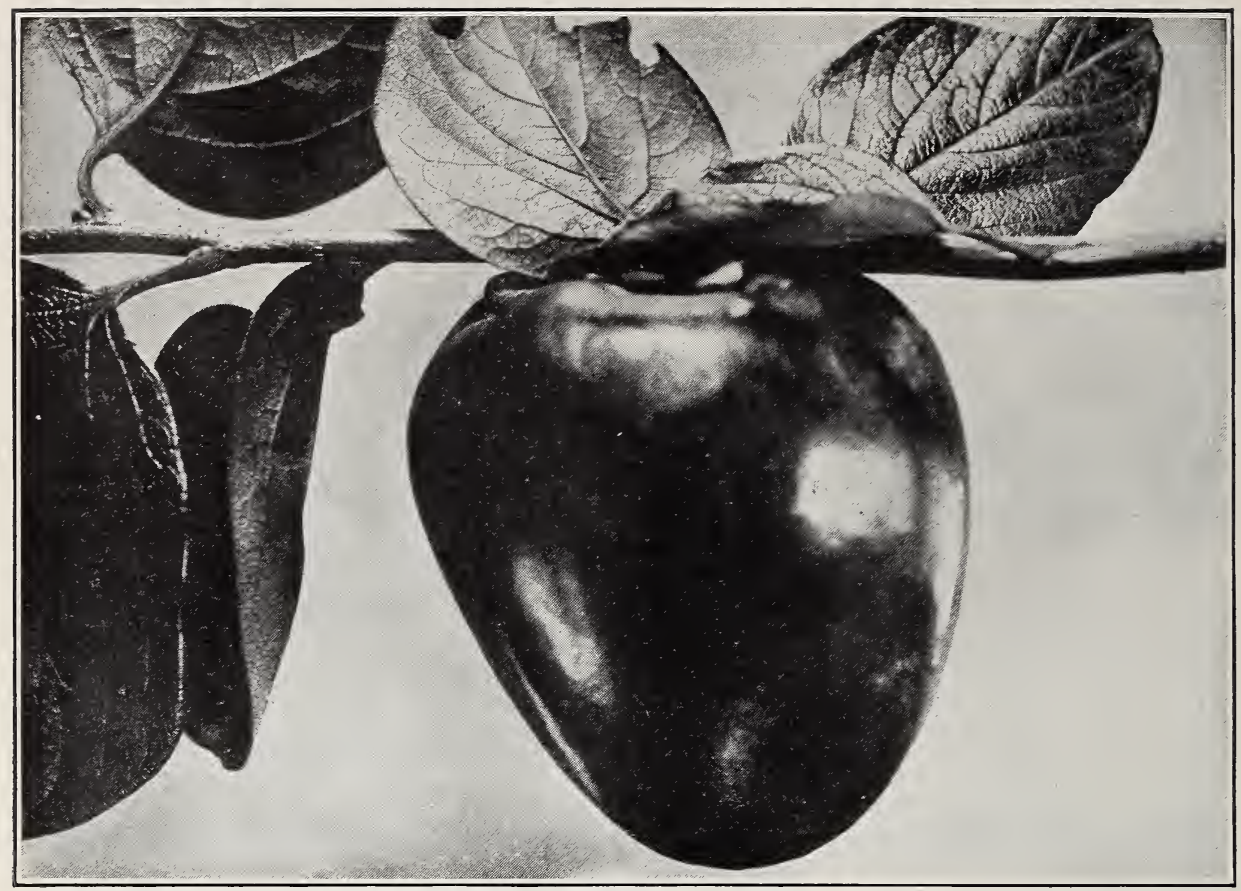

Hachiya Persimmon

Okame. Large, about $23 / 8$ by $31 / 8$ inches; roundish oblate, somewhat four-sided. Orange yellow changing to brilliant carmine, with delicate bloom. Flesh light yellow, with dark brown around seeds. Astringent until nearly ripe. Quality best. Very vigorous and prolific.

Tane-nashi. Large to very large, about $3 \frac{1}{4}$ by $33 / 8$ inches, roundish conical, pointed; very smooth, symmetrical and handsome. Light clean yellow, changing to deep reddish orange color when ripe. Flesh clear yellow and seedless. Quality very fine. The most desirable market variety. Tree vigorous and very prolific.

Triumph. Medium to small sized; tomatoshaped. Skin yellow, flesh yellow, generally a few seeds which are not surrounded by dark flesh as is the case with most varieties. Quality excellent. Very productive. Ripens from September to November.

Tsuru. Medium size; long, slender, skin bright red; flesh orange-yellow; some dark flesh around the few seeds; astringent until fully ripe; then good. The latest of all to ripen. Good grower and bearer.

Yeddo-ichi. Large size; oblate, very smooth and regular in outline with dinted appearing surface. Slight depression at blossom end; skin red, with heavy bloom; flesh very dark, sweet, rich, crisp; one of the best; not astringent. Good grower and bearer.

Yemon. Large, about $2 \frac{1}{2}$ by $3 \frac{1}{4}$ inches; flat tomato-shaped; slightly four-sided; skin light yellow changing to dull red mottled with light yellow; flesh dull red, brown around the few seeds; occasionally seedless and entirely light fleshed; astringent until it begins to soften, then very fine; one of the best.

Zengi. Small size, nearly round; skin reddisb yellow; flesh very dark: quality good, not astringent. One of the earliest; vigorous and prolific.

\section{Apples}

Apples can be grown in Florida and all along the Gulf Coast country. Of course we don't recommend planting large commercial orchards, but a few trees for home use or even for a small local market, are all right. The Jennings Florida Apple (originated in Baker County, Fla.) has proven quite fruitful in many sections of the lower South, and the other varieties we list also give fair results. Let us send you a few trees-we believe you will be agreeably surprised when they commence bearing. 


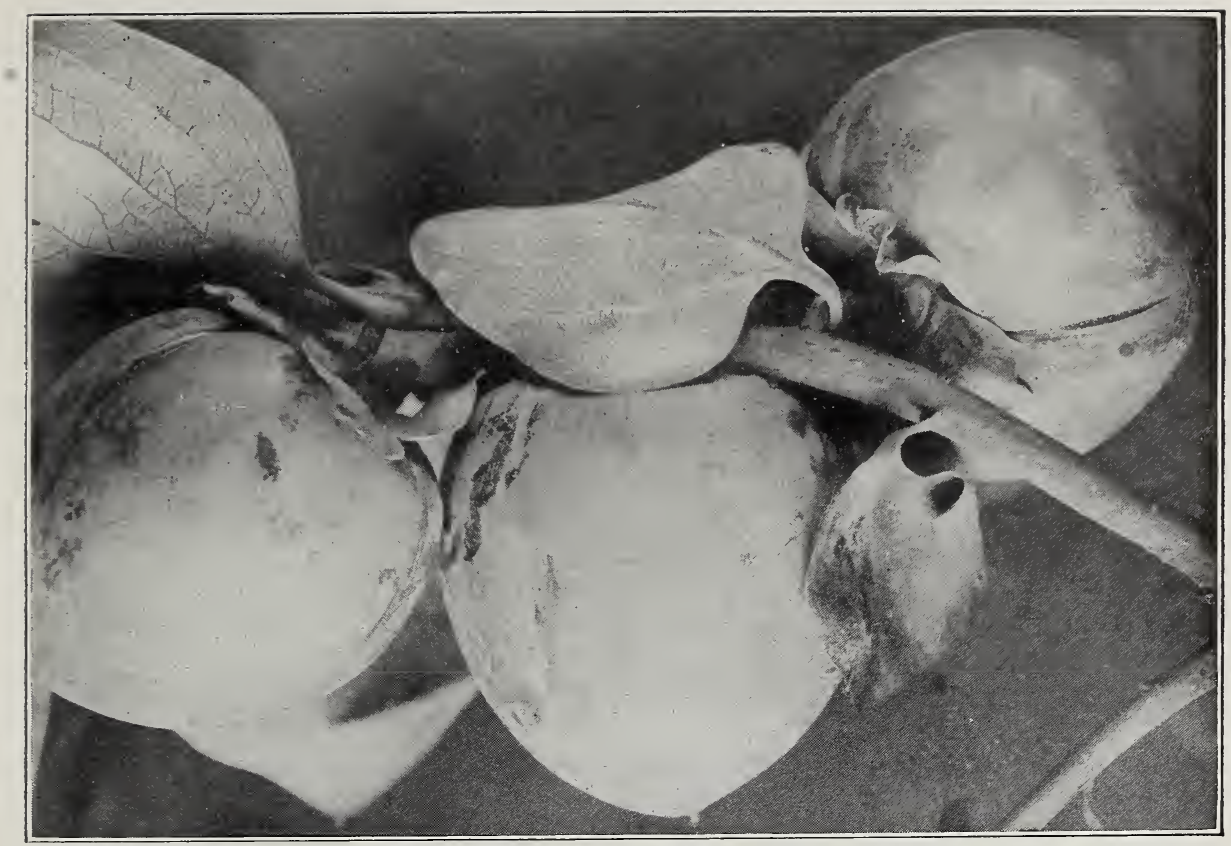

Tane-nashi Persimmons-The best market kind

PRICES ON APPLES.

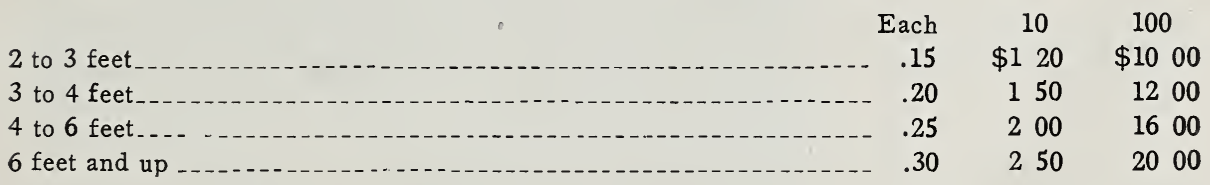

Ben Davis. One of the most extensively grown for market purposes in the apple-growing sections of the North, on account of its large size, fine appearance and splendid keeping qualities. Quality fair, subacid. A late ripening sort.

Early Harvest. Another well known and popular variety; medium to large; yellow, juicy, tender and fine flavor. Ripens in June.

Horse. Medium large, roundish, yellow, striped red; early; quality fair.

Jennings. (Jennings' Florida.) This variety was found growing and fruiting well in Baker County, Florida, some years ago. Has proven the most satisfactory kind for Florida and the extreme South. Large, oblate; color green. Flesh white, juicy, subacid, good for either eating out of hand or for cooking. Ripens in June. Tree vigorous and 2 heavy annual bearer.

Red Astrachan. Adapted to a wonderful range of country; a fine variety in Maine and one of the best in Northern Florida, does very well all along the Gulf Coast country. Large, crimson, with heavy bloom; crisp, juicy, slightly acid. Ripens in June.

Red June. Medium size, conical, deep red, juicy, productive. June 20 to July 15.

Yellow Transparent. Medium size, yellow; early; quality fair, rather acid.

\section{Crab Apples}

Hyslop. Large, produced in clusters, dark rich red.

Whitneys. Large, almost red striped, flesh yellowish white; very juicy, subacid; excellent. Tree vigorous. 


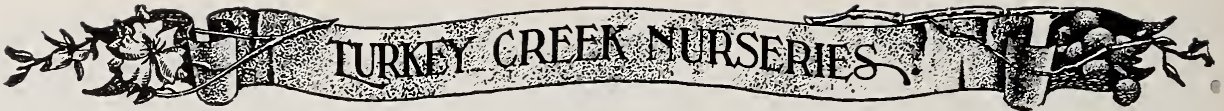

Figs

One of the most delicious of fruits, whether served fresh, with cream and sugar, or preserved or pickled, or in fact prepared in any of the numerous ways in which it can be made so palatable. Does well most everywhere in the lower South. Should be planted to a much greater extent for both home use and commercially, for it is very profitable when properly marketed.

\section{PRICES ON FIGS.}

Each $10 \quad 100$ yr., 1 to $2 \mathrm{ft}$. $.15 \$ 130 \$ 1000$ $1 \mathrm{yr} ., 2$ to $3 \mathrm{ft}$. $.20 \quad 160 \quad 1400$ 2 yrs., 3 to $4 \mathrm{ft}$. $.25 \quad 200 \quad 1800$ 2 yrs., 4 ft. up. $.40 \quad 300 \quad 2500$

Brown Turkey. Medium size, color brown; sweet and of excellent quality. Tree very prolific and hardy.

Brunswick. A late variety and one of the best. Very large, violet color; sweet and delicious.

Celestial. The small sugar fig. Strong grower, very prolific; commences ripening quite early and continues for a long season; color violet. Very sweet and finely flavored. One of the most satisfactory and probably the hardiest in the list.

Magnolia. Fruit of large size, light-colored, handsome, vigorous grower, prolific, excellent for canning; a favorite with Texas planters.

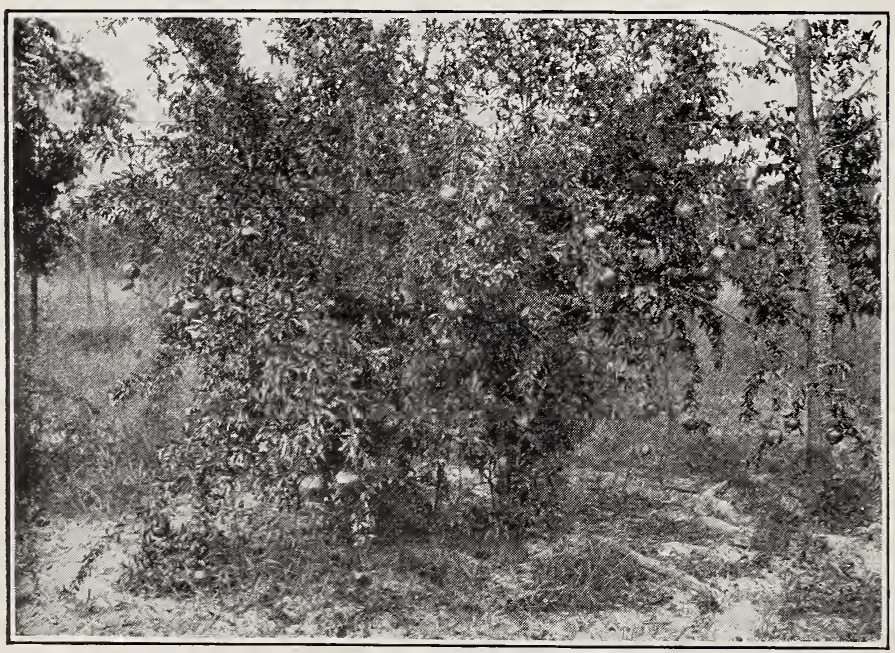

Pomegranates-Purple-seeded

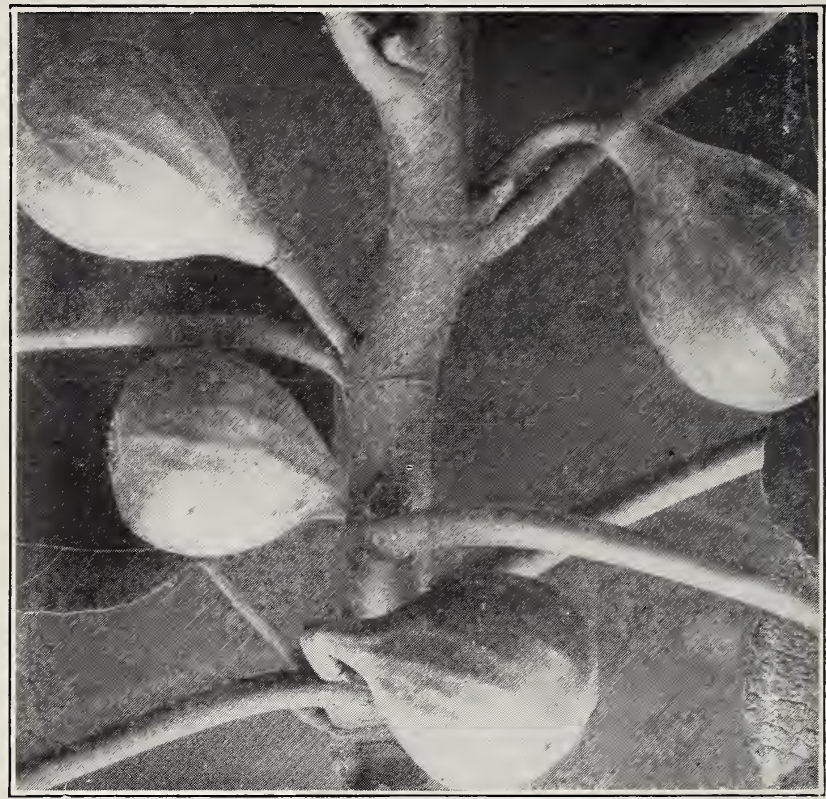

Celestial Fig

\section{Pome-}

\section{granates}

A large shrub or small tree, quite or $n$ amental in character of growth and foliage. Blooms very freely, and flowers are strikingly brilliant, of a lovely scarlet color. Bears early and heavily and fruit is very much liked for its crispness, delicacy and sprightliness by those who know it. 


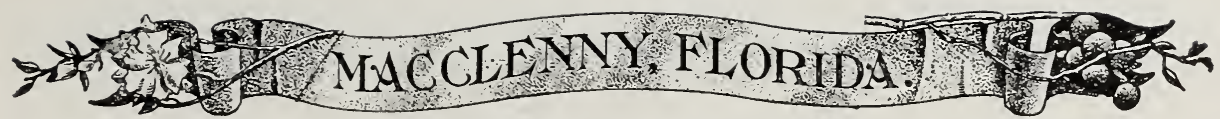

PRICES ON POMEGRANATES.

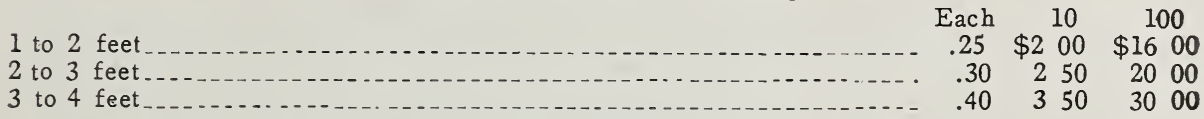

Purple Seeded. Very large, rind thin. Juicy celis which surround the seeds (the edible portion of the fruit) are dark wine red color, sprightly, vinous and finely flavored. One of the best varieties. Quite ornamental.

\section{Loquat}

(Eriobotriya Japonica, Japanese Medlar, Biwa of the Japanese.)

Broad-l e a ve d evergreen tree of tropical habit; very handsome, gives a tropical touch to grounds where planted. Leaves a re large, dark green and rough; the young twigs are woolly. A symmetrical, compact

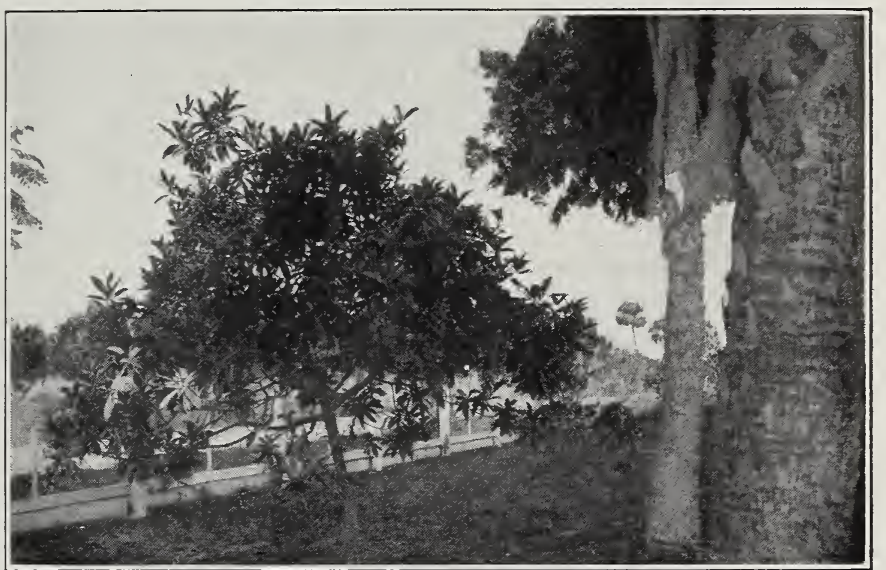

Loquat-Fruit Makes Excellent Jelly grower, forming a well rounded head. Fruits when quite young, the fruit being about 1 to $1 \frac{1}{2}$ inches in diameter, generally oblong; beautiful; clear yellow; somewhat acid; very desirable for cooking and makes a delicious jelly.

\section{PRICES ON LOQUATS-FROM SEED.}

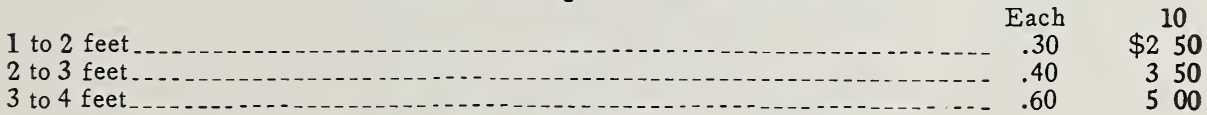

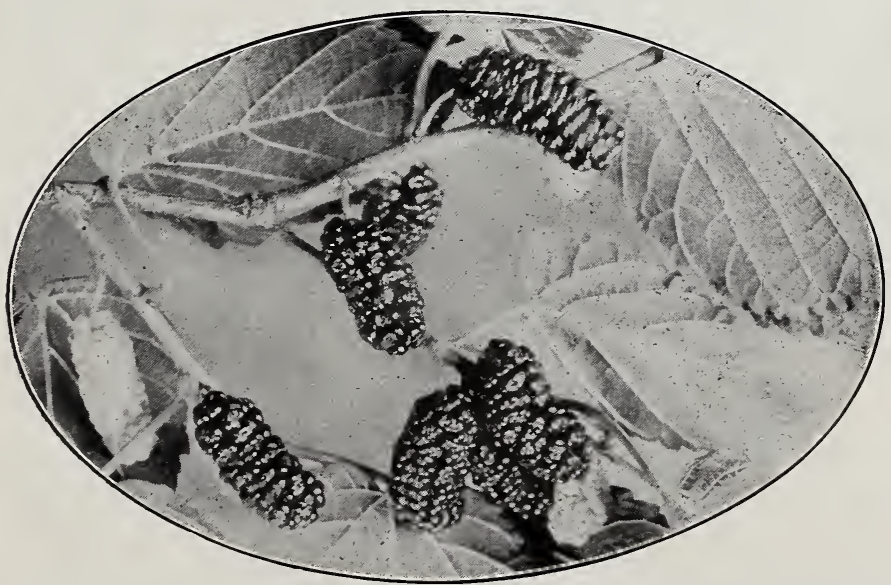

Stubbs Mulberry

Mulberries are excellent for Hogs and Poultry

\section{Mulberries}

The mulberry is a very rapid growing tree which can be trained into a beautiful symmetrical shape and be made into a desirable shade tree. The berries, which are produced in great profusion, form an economic food for swine or poultry. Birds are very fond of them and the trees are often grown for tolling birds away from other fruits. 


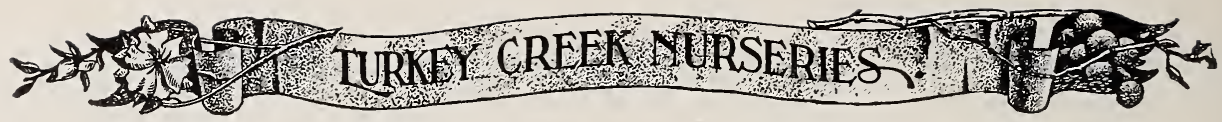

PRICES.

Each $10 \quad 100$

$1 \mathrm{yr}, 2$ to $3 \mathrm{ft}$.....15 $\$ 120 \$ 1000$

$1 \mathrm{yr}, 3$ to $4 \mathrm{ft}$.... .20 $150 \quad 1200$

$1 \mathrm{yr}, 4$ to $6 \mathrm{ft} \ldots . .25 \quad 200 \quad 1600$

$1 \mathrm{yr}, 6$ feet up...30 $250 \quad 2000$

Downing. One of the handsomest growers, makes 2 beautiful rapid growing shade tree. Berries subacid and of good quality.

Hicks. (Everbearing.) Medium sized black berries, very sweet, rather insipid. Tree a rapid grower; rery productive; continues in bearing nearly four months. Especially desirable for a poultry yard or for swine.

Stubbs. Very large black berries of excellent quality. Very productive. A handsome tree, broad, healthy foliage; a form of the native red mulberry, discovered in Georgia.

Multicaulis. (Morus Multicaulis.) The silk worm

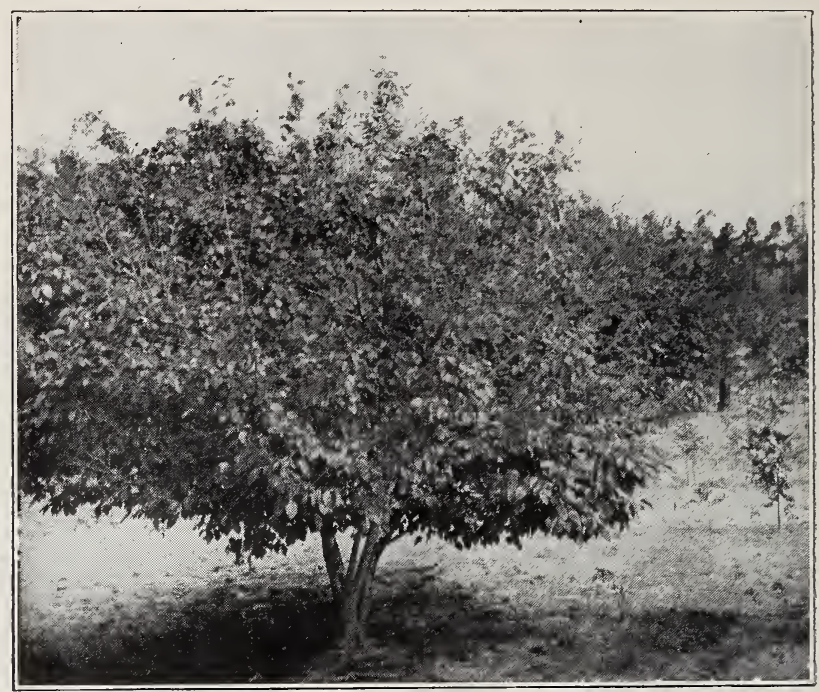

Mulberry Trees

Make Fine, Quick Growing Shade Trees tree, used principally here as a stock upon which to grow other varieties. Very vigorous. Makes a desirable shade tree.

White. (Morus Alba.). Rapid grower, prolific; berries large and sweet; color white.

\section{Apricots}

This fruit, which has met with so much success in California, is not recommended for extensive planting in the lower South. But there are a few varieties that do fairly well. The kinds listed here are the best for this section.

PRICES ON APRICOTS ON PLUM STOCK.

1 year, 2 to 3 feet.
1 year, 3 to 4 feet. 10

Bungo. (Bungoume.) A Japanese variety of fair quality; good size and golden yellow color.

Hubbard. Another Japanese kind; bright yellow color, large size and fair quality; said to be semi-tropical in habit.

Santa Fe. Originated in Alachua County, Fla., near Lake Santa $\mathrm{Fe}$, where it has borne well. Probably the best variety for the extreme South. Ripens May 20 to June 5, blooms late, seldom caught by frost while in bloom; medium size, round or somewhat flattened; yellow with reddish brown spots; flesh pale yellow; freestone; quality excellent. Strong grower.

\section{Quince}

Quinces are not commercially a success in the lower South, but they sometimes produce fruit, and as the fruit is very generally liked for cooking, it is a good idea to plant a few trees about the home grounds.

Meech. Fruit of large size, orange color, very attractive; quality excellent; one of the best for cooking. Bush a vigorous grower.
Orange. Large golden yellow with firm flesh and excellent flavor. A strong grower and thrifty variety. 


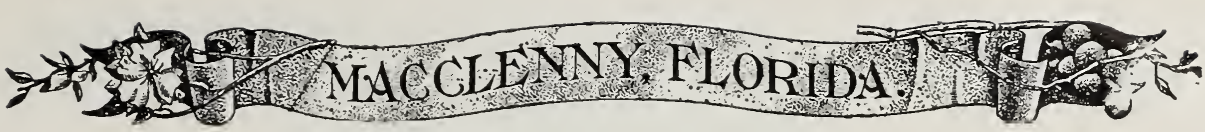

PRICES ON QUINCES.

2 to 3 feet
3 to 4 feet
4 to 5 feet

\section{Huckleberry}

Huckleberries grow well all through the South, and when cultivated they produce very fine berries. We have selected the wild high bush huckleberry to offer our customers, for we know this kind will give an abundance of fine berries. Try a few plants.

PRICES ON COLLECTED PLANTS. Each

2 to 3 feet 3 to 4 feet

\section{Grapes}

Bunch Grapes. There are several varieties of bunch grapes that bear well in the lower South, and for a local market prove profitable, but do not ship very well, for the berries do not adhere to the stems. For home use they are an unqualified success; they make excellent jell y, preserves or wine and are delicious for eating fresh.

Muscadine Grapes. The Muscadine type of grapes is at home in the South,

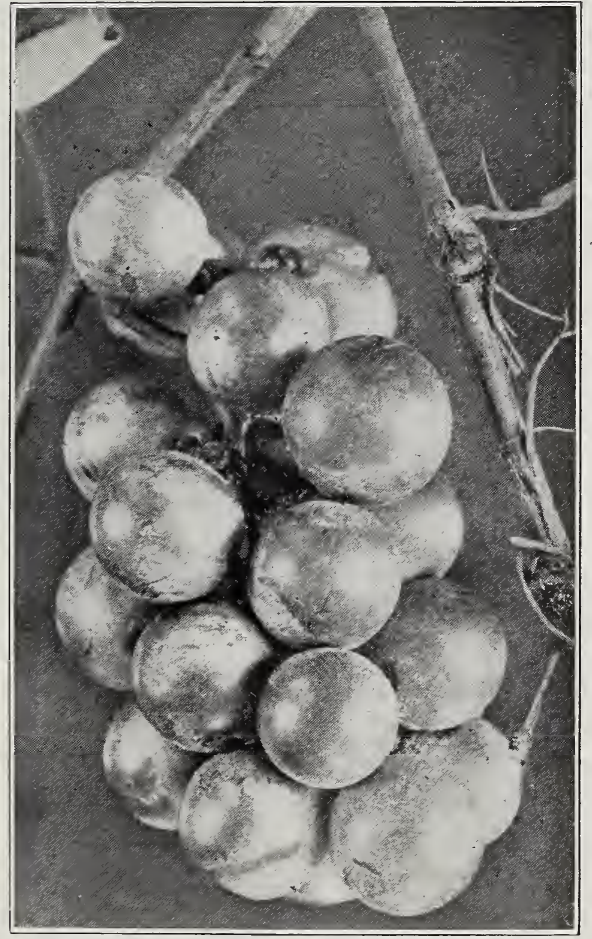

Niagara Grapes Grown on Turkey Creek Nurseries A good bunch grape for Florida planting. Bears well are rank growers and heavy bearers. They also are desirable for jelly, preserves or wine and eating in a fresh state. They have a very agreeable musky flavor that is generally liked. Every home should have several vines of both Bunch and Muscadine grapes.

Varieties of bunch grapes should be trained on trellises about 8 to 10 feet apart and pruned back each winter when dormant. Varieties of the Muscadine type should be trained on arbors 15 to 25 feet apart; they require no pruning.

$$
\text { PRICES ON GRAPES. }
$$

Each

10 100

1-year vines

$\$ 120 \quad \$ 900$

$160 " 1200$

2 -year vines

$250: 2000$

Catawba. Medium large red berries of good quality, ripening very late. Originated in North Carolina.
Concord. Blue-black berries of large size, and in large bunches; covered with bloom, flesh pulpy, sweet, tender; excellent. Vigor- 


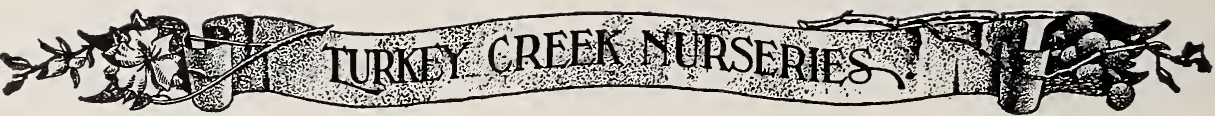

ous grower and very prolific. July. Desirable for nearby markets, but too tender for long shipments.

Delaware. Berries small, reddish or pink, skin very thin; pulp sweet, juicy, vinous; quality best. Bunches medium. One of the best for Florida and the Gulf Coast country.

Diamond. Bunches large, berries white and of fine quality. About ten days earlier than Niagara. Well adapted to the South and one of the best. Has done well in South Florida.

Eden. Berries black, medium size, somewhat acid. A good wine grape. Seedling of Scuppernong. Bears early; very productive.

Flowers. Medium to large b l a c k berries, unusually large bunches for the Muscadine type, generally 15 to 20 berries to the bunch. Sweet, nicely flavored. August and September.

Ives. Berries small, skin red or pink, very thin; juicy, sweet, vinous; quality excellent. Bunches medium. Ripens July. One of the best in the South.

James. Very large black berries, often $3 / 4$ to $1 \frac{1}{4}$ inches in diameter; sweet, juicy, excellent. The largest and one of the best of the Muscadine family; has taken a number of first premiums. Commences ripening about August 1st and continues until late fall. Good shipper. Very productive.

Meisch. One of the Muscadine type; berries and bunches medium size; black, quality good. Very similar to Flowers variety. Bears well and adapted to Florida and all through the South.

Moore's Early. Earlier and of better quality than Concord, but otherwise quite similar.

Niagara. Large, greenish yellow berries, produced in large bunches; quality excellent; early, vigorous and productive. A fine market variety. One of the best in the lower South.

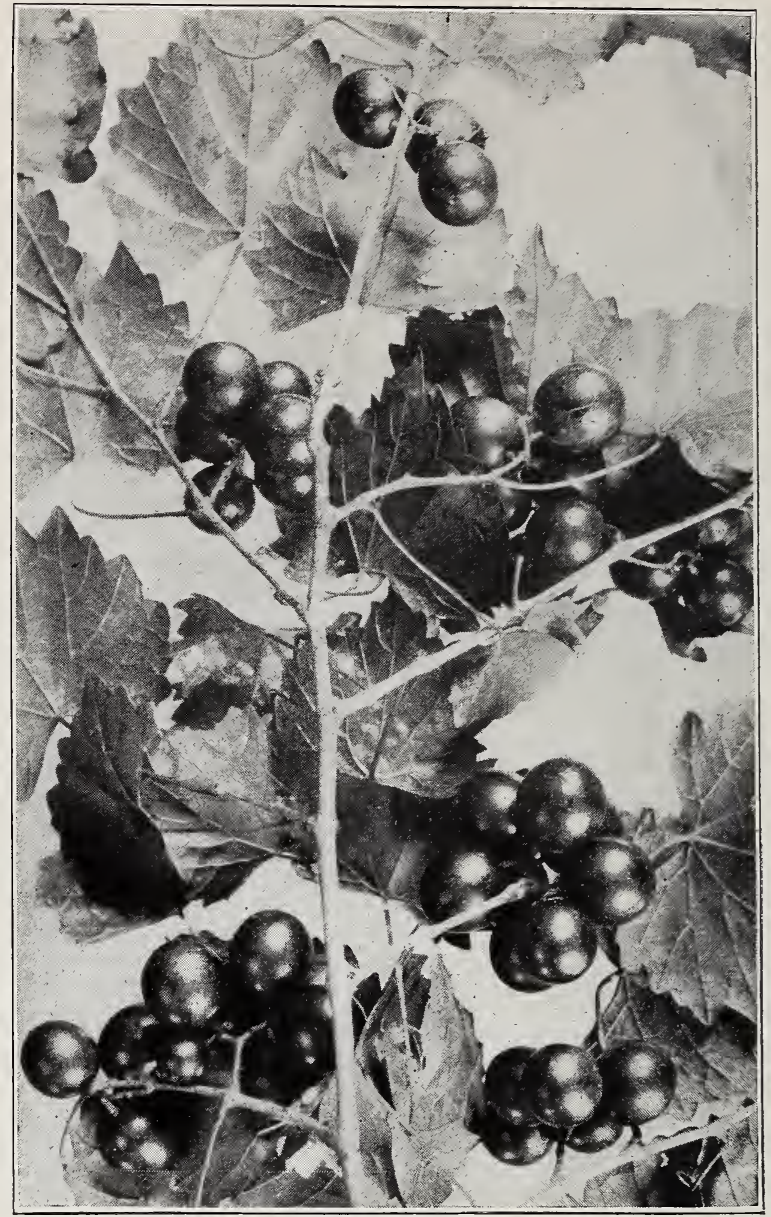

Flowers Grapes

A Heavy Bearer of the Muscadine Type

Scuppernong. Large greenish yellow berries, bronze colored when fully ripe. Bunches of 8 to 12. Pulp sweet with peculiar agreeable musky flavor; quality excellent. One of the best of the Muscadine type. August and September.

Thomas. Small sized berries of a reddish purple color, usually 8 to 10 to the bunch. Pulp sweet, tender, juicy and sprightly; one of the finest flavored of the Muscadine type. August and September.

\section{Budded Pecans}

Within the last few years Pecans have been attracting a great deal of attention on account of the enormous profits to be derived from groves of large thin-shelled varieties. The trees are easily transplanted, require comparatively little attention (although 


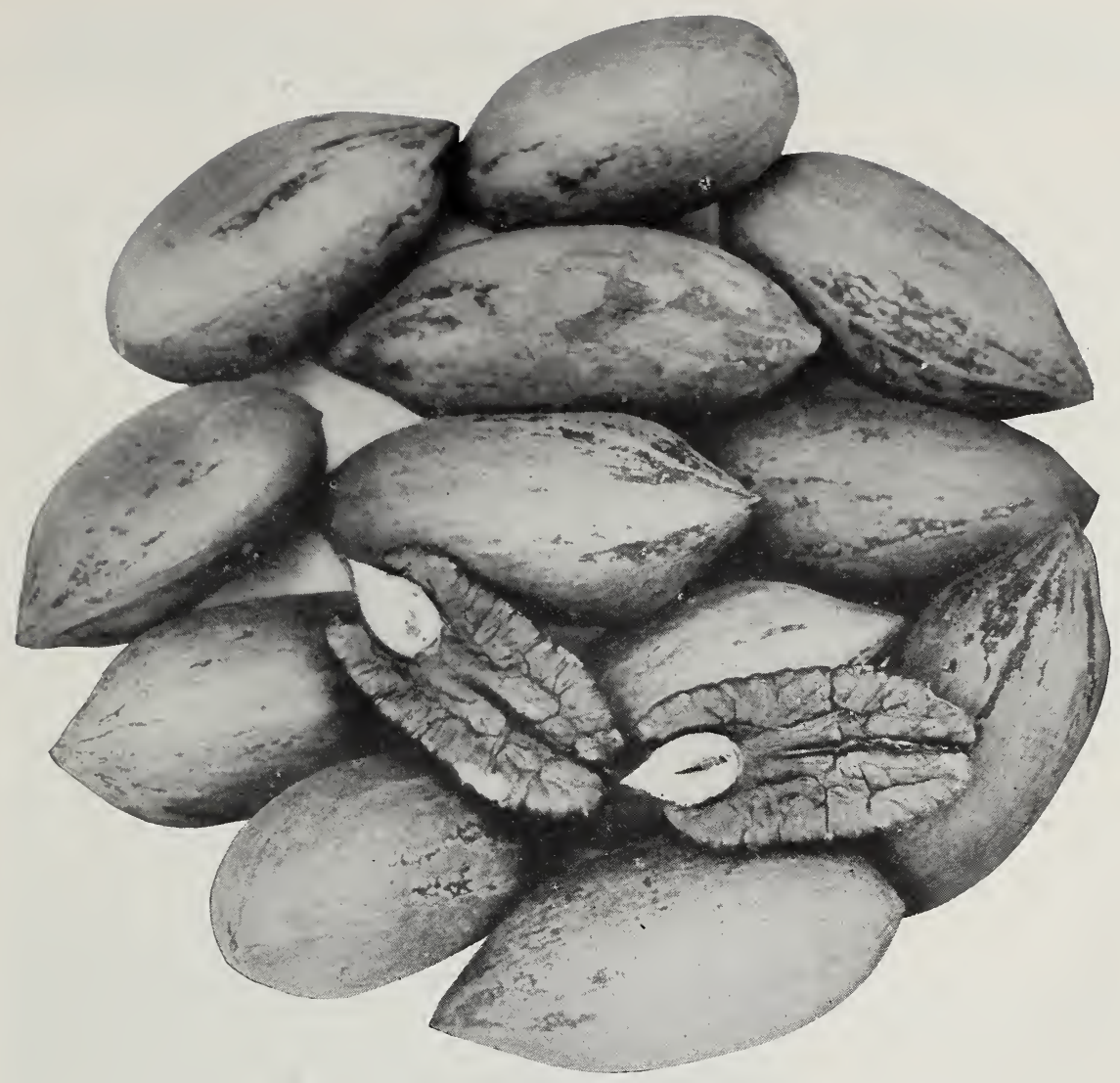

Van Deman Pecans

One of the very best varieties, heavy bearers, large fine nuts

they respond readily to liberal treatment), and when they commence bearing-usually six to ten years from the time of planting - they produce heavy annual crops, if proper kinds have been set. The nuts are easily gathered, and can be marketed any time within a year or so, when best prices can be obtained. The demand for the nuts, especially of the larger, finer sorts, is rapidly increasing. Unlike most fruits, the Pecan is used the year round.

The trees are upright growers and form well-rounded, symmetrical tops, making them desirable for shade trees. In planting shade trees, why not plant some kind that will not only prove excellent for this purpose, but will give a crop of nuts annually that will sell at a good profit?

In planting trees, care should be used to see that only first-class varieties are set; and these should be purchased only from the most responsible nurserymen. The best budded trees are cheapest and best in the end, for when you set a budded tree of known variety you can depend on getting first-class nuts when the tree commences bearing, while if seedling trees are set there will be a great variety of nuts, some good; but many inferior.

We have an especially fine lot of budded trees of the most popular and valuable kinds, and all are guaranteed true to name. 


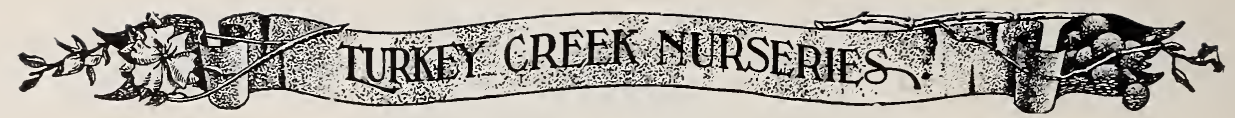

PRICES ON BUDDED PECANS.

\begin{tabular}{|c|c|c|c|c|}
\hline $\begin{array}{l}\text { to } 2 \text { feet } \\
\text { to } 3 \text { feet } \\
\text { to } 4 \text { feet }\end{array}$ & $\begin{array}{r}\text { Each } \\
.65 \\
.90 \\
110 \\
1125 \\
1 \quad 75 \\
200\end{array}$ & $\begin{array}{rc} & 10 \\
\$ 5 & 50 \\
7 & 50 \\
9 & 00 \\
11 & 00 \\
13 & 00 \\
17 & 50\end{array}$ & $\begin{array}{rl} & 100 \\
\$ 45 & 00 \\
6000 \\
7500 \\
9000 \\
11000 \\
15000\end{array}$ & $\begin{array}{r}1000 \\
\$ 40000 \\
55000 \\
70000 \\
85000 \\
100000\end{array}$ \\
\hline
\end{tabular}

Centennial. Large size, oblong, quite pointed at both ends; fine appearance ; fairly thin shell; kernel plump; quality good. One of the oldest named varieties.

Columbian. (Syns. Rome, 20th Century, Prideof-the-Coast.) An extremely large nut of fair quality; oblong, ovoid; kernel sound.

Curtis. Mediumsize, 15/8 by $7 / 8$ inch; ovate conical, compressed, base rounded; pointed apex; shell thin, cracks easily; kernel compact, firm, sweet, rich; quality excellent. A good bearer.

Dewey. M e dium to large, ovate, pointed, base rounded, apex sharp, shell thin and brittle; cracks easily; quality good; kernel full, plump, smooth, firm and solid; sweet, rich.

Formosa. Introduced by Mrs. Jacocks, of Formosa. One of her famous collection. Large size; finequality.

Frotscher. Large sized, very thin shelled $\mathrm{nuts}$, about $15 / 8$ by 1 inch; color bright yellowish brown with a few black splashes at apex. Fills clear to the ends; blunt at both ends; cracking quality excellent; kernel good flavored. A first-class variety.

Georgia Giant. Large size; base rounded; apex tapering, blunt; shell medium thickness, brittle; kernel plump, full flavor, sweet; quality good.

Jacock's Perfection. An extremely large nut of fine quality introduced by Mrs. Jacocks, of Formosa. Has taken premiums wherever exhibited. Nuts 2 to $2 \frac{1}{2}$ inches long, quite pointed at both ends; shell medium thickness.

James. A medium sized nut; extremely thin shelled; fine quality. Exceptionally heavy bearer. Originated in Louisiana.

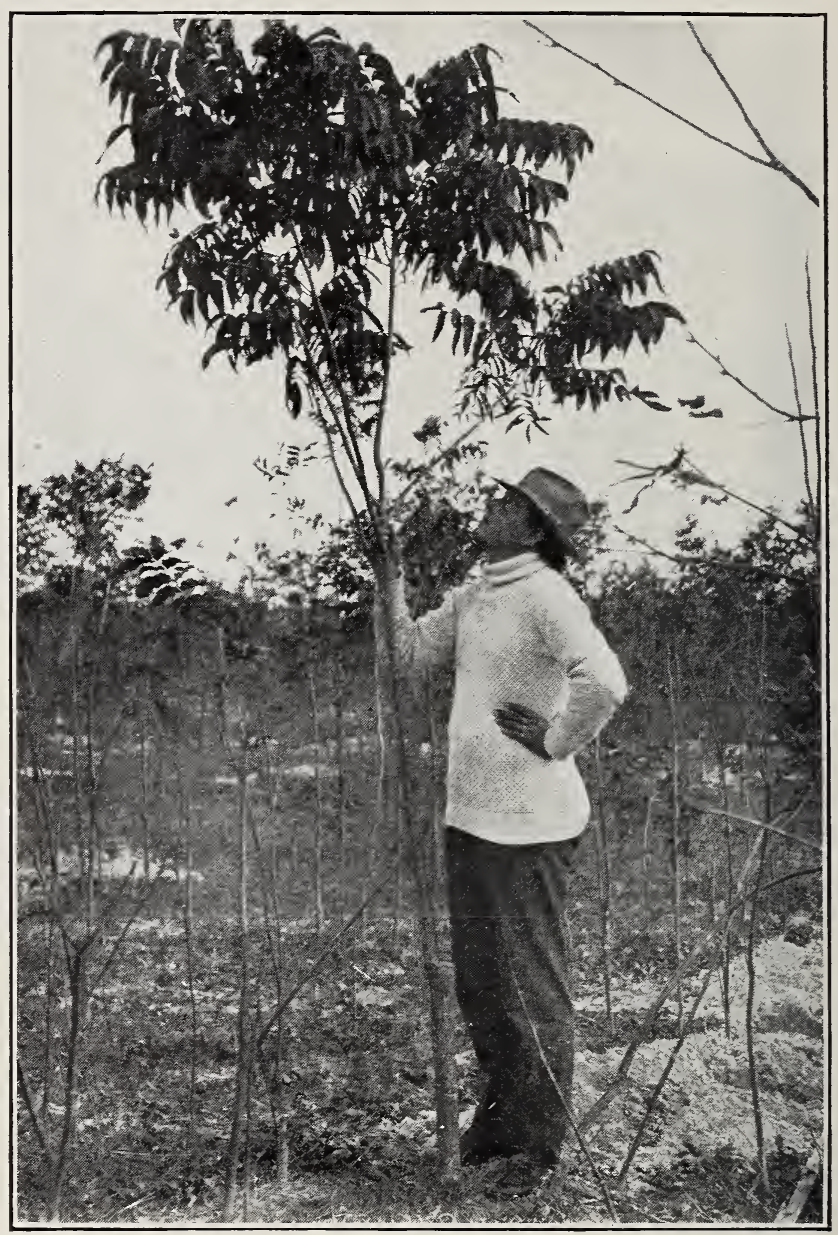

Pecan Tree in our Nursery, showing one year's growth of bud

Moneymaker. Medium size, ovate oblong; light yellowish brown, bright, clean looking nuts; shell medium thickness; cracks well; kernel full, plump, firm, solid, sweet, excellent. A heavy bearer.

Schley. Large size, generally about $17 / 8$ by $7 / 8$ inch, oblong, light reddish brown, specked at base; shell thin, brittle, cracking quality excel- 


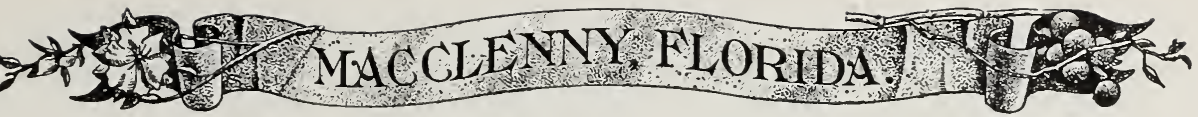

lent; kernel plump, smooth, full; flavor rich and sweet. A good grower and heavy bearer. Ripens in October.

Stuart. Large to very large, about $1 \frac{7}{8}$ by 1 inch; grayish brown, dotted with purplish black; base rounded; blunt both ends: shell medium thickness, cracking quality very good: kernel large, full, plump, solid, fine grained; flavor rich, sweet; quality good; a strong grower and a heavy bearer. Has proven adapted to a very wide range of country. One of the best; in fact, generally conceded the best, all things considered.

Sweetmeat. Medium size, about $1 \frac{1}{4}$ by $\frac{7}{8}$ inch, oblong, shell thin, cracking quality good; kernel plump, full, sweet, good.

VanDeman. Large to very large, about $2 \frac{1}{8}$ by $7 / 8$ inch, obleng, cylindrical; reddish brown; pointed; shell medium thickness; kernel fine grained, compact, sweet and delicious; quality excellent. A good grower, produces well. rieties.

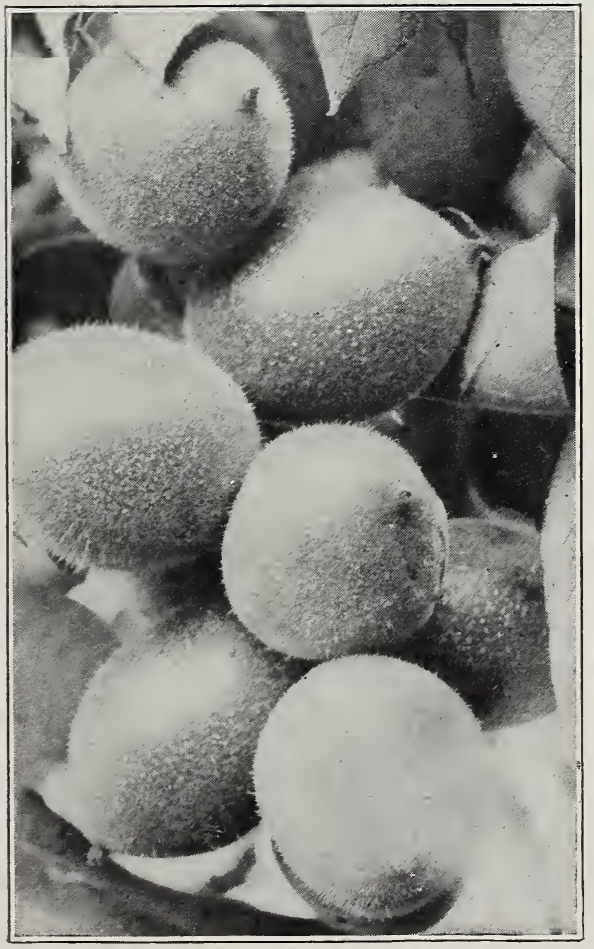

Japan Walnuts

Well adapted to the South. (See next page.)

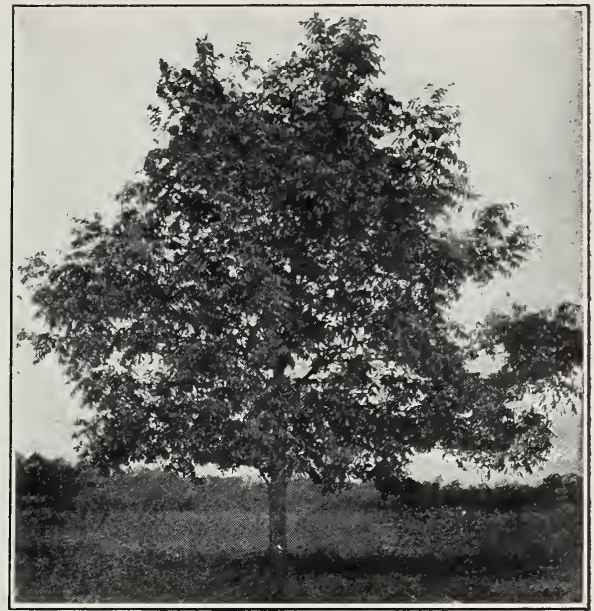

Pecan Trees

Make Fine Shade Trees as Well as Produce Large Crops of Delicious Nuts.

One of the finest and most profitable va-

\section{Seedling Pecans}

As a general rule seedling pecans are rather stronger and more rapid growers than budded or grafted trees, but do not bear quite as soon. While seedling trees are'apt to vary considerably from parent trees, if large fine nuts are planted a good portion of the seedlings generally produce good nuts.

For street or grounds planting for shade, the pecan is one of the most desirable trees, and we can furnish some fine large seedling trees, grown from selected nuts of large size and good quality at very reasonable prices on large lots. On regular sizes we quote:

PRICES ON SEEDLING PECANS.

\begin{tabular}{|c|c|c|c|c|}
\hline & $\mathrm{Eac}$ & 10 & 100 & 1000 \\
\hline to $2 \mathrm{ft}$. & .20 & $\$ 160$ & $\$ 1300$ & $\$ 10000$ \\
\hline $\mathrm{ft}_{-}$ & .30 & 250 & 2000 & 15000 \\
\hline 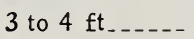 & .40 & 350 & 3000 & 00 \\
\hline & .50 & 400 & 3500 & 300 \\
\hline 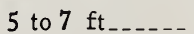 & .60 & 500 & 450 & 400 \\
\hline
\end{tabular}




\section{Walnuts}

English Walnuts have not proven generally satisfactory in the South, but it often happens that our customers want a few trees for trial or for filling out collections, therefore we grow a few trees of one of the best varieties. Japan Walnuts have proven well adapted in the South. They are strikingly handsome trees and bear well, nuts of good size and fine quality, but which, on account of their thick shells, are not recommended for extensive commercial planting.

PRICES ON WALNUTS FROM SEED.

Each 10

1 to 2 feet

2 to 3 feet $\ldots \ldots \ldots$

Japan. Large size nuts; black, rough, rather thick shelled; kernel flavor of butternut, but not so oily; better quality. Nuts

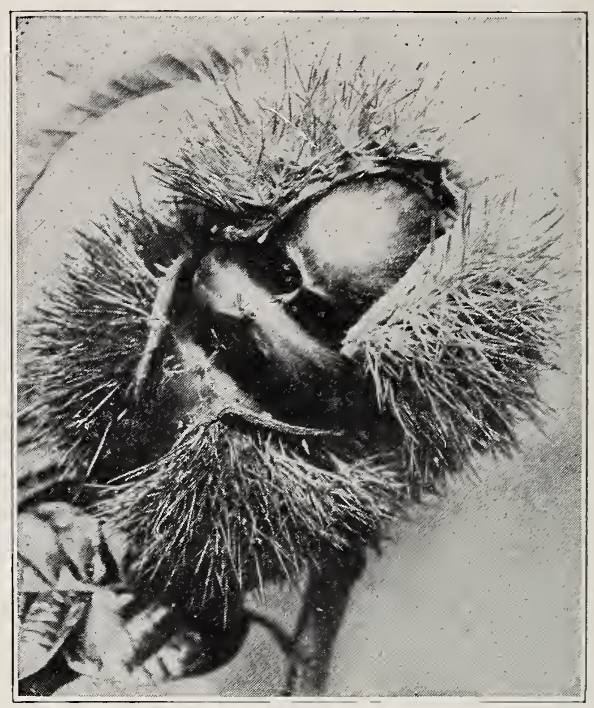

Japan Mammoth Chestnut

borne in clusters. Rapid grower and forms very handsome tree of rather spreading, graceful habit.

\section{Japan Mammoth Chestnuts}

An immense chestnut of rather inferior quality; grows well and fruits fairly well in the South. Hzadsome tree. Worthy of being planted in a small way on the home ground.

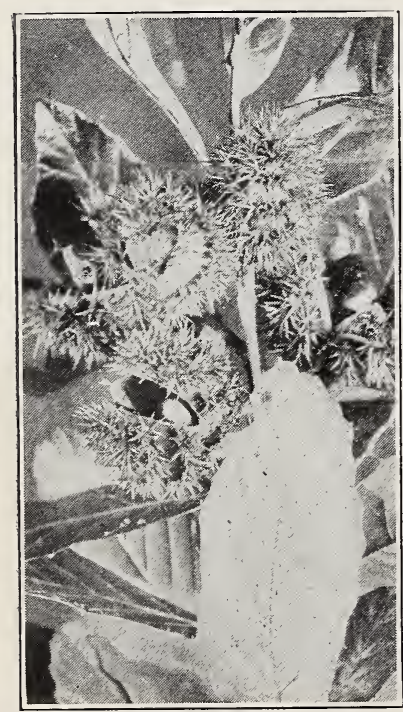

Chinquapin

A fine native nut that is easily grown

PRICES.

Each 10

1 to 2 feet

.25

2 to 3 feet

.30

3 to 4 feet

$\$ 200$

250

300

\section{Chinquapins}

A shrub, or small tree, found growing wild in many sections of the South. Produces an abundance of sweet, nicely flavored nuts; quite attractive when in bloom. The plants we offer are collected.

$$
\text { PRICES. Each } 10
$$

1 to 2 feet

2 to 3 feet

\section{Almonds}

While almonds are not recommended for commercial planting in the South, it is well enough to plant a few trees to fill out collections. They fruit occasionally. The two varieties, Princesse and Sultana, are the principal kinds seen on the markets.

PRICES ON ALMONDS ON PEACH STOCKS.

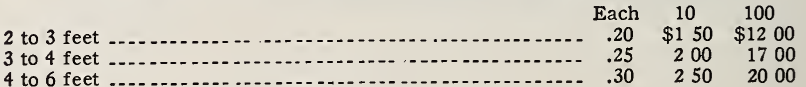




\section{Roses}

Among flowering plants, there are none more generally satisfactory than the Rose. They are adapted to nearly all soils, and suitable to various forms of planting; as shrubs about the grounds they are very ornamental; as borders for walks or driveways ihey form beautiful flowering hedges; massed together they can be formed into attractive figured plots; or set at edges of woodlands, they add color and make a striking foreground; or used as veranda vines the climbers form a mass of green with red, or yellow, or pink, or white, or combination of several, which is surprisingly beautiful. When planted in almost any way, they furnish an abundance of flowers almost the whole year if proper varieties are planted.

As some varieties are better adapted to some localities or for particular purposes, care should be used in making selection. If desired, we will be pleased to help our customers in selecting best varieties or will make a selection for them when requested. With our knowledge of the different kinds and their characteristics, this often proves the most satisfactory method.

Our Roses are mostly grafted upon Mad. Plantier and are strong field-grown plants, far superior for Southern planting to the small plants on their own roots as usually sent out by Northern growers.

Roses have been divided into different classes and the class often indicates to a certain extent the territory where those kinds are adapted. Following the names of the different varieties in the descriptions will be found initial letters indicating these classes. The key to these initials is as follows:

Bk., Banksia; Beng., Bengal; Bour., Bourbon; C. B., Climbing Bengal; C. C, Climbing China; C. N., Climbing Noisette; C. T., Climbing Tea; H. C., Hybrid China; H. N., Hybrid Noisette; H. P., Hybrid Perpetual; H. T., Hybrid Tea; Mult., Multiflora; N , Noisette; Pol., Polyantha; P., Prairie; T., Tea; W., Wichuraiana.

PRICES OF ROSES.

\begin{tabular}{|c|c|c|c|}
\hline $\begin{array}{l}\text { 1-year, strong open-ground-grown } \\
\text { 2-year, large, strong, open-ground-grown }\end{array}$ & $\begin{array}{l}\text { Each } \\
.25 \\
.35\end{array}$ & $\begin{array}{r}10 \\
\$ 200 \\
300\end{array}$ & $\begin{array}{r}100 \\
\$ 1700 \\
2500\end{array}$ \\
\hline
\end{tabular}

American Banner. (T.) Medium to large, finely formed; creamy white or light salmon, sometimes striped red. Good grower and free bloomer.

American Beauty. Flnwers very large, of beautiful form and very double; color a deep rich rose. The fragrance is delightful, resembling LaFrance or the old-fashioned Damask Rose; it is truly an everbloomer, each shoot producing a bud.

Archduke Charles. (Beng.) Crimson scarlet, marbled with lighter shades.

Baby Rambler. (Mme. Norbert Le Vavasseur). (P.) This new rose is of dwarf habit, and is continually in bloom from early spring until frost. Flowers produced in clusters; color dark crimson, similar to Crimson Rambler. It is perfectly hardy and stated to be free from mildew. At the approach of cold weather the plants can be lifted, potted off and brought in the house, where they will bloom throughout the winter.
Bengale Nobinand. (Beng.) Velvety, reddish-purple; vigorous grower, and produces perfect flowers throughout the entire season. $A$ very attractive rose, and one of the most valuable of its class.

Blanche de Meur. (H. P.) Pale, pink or blush, changing to white.

Bon Silene. (T.) Bright rosy salmon, inner petals carmine. Very fragrant. Finely formed buds. Very vigorous and profuse and constant bloomer.

Bougere. (T.) Large, double and full and very sweet tea fragrance; bronze-rose or violet crimson, shaded with lilac. Profuse bloomer.

Bride. (Tea.) One of the very best pure white everblooming roses in cultivation, extra large buds and flowers, pure creamy white, sometimes tinted blush. The leading white rose for cut flower purposes, also an excellent bedding rose. 


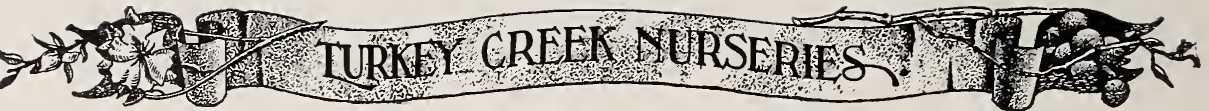

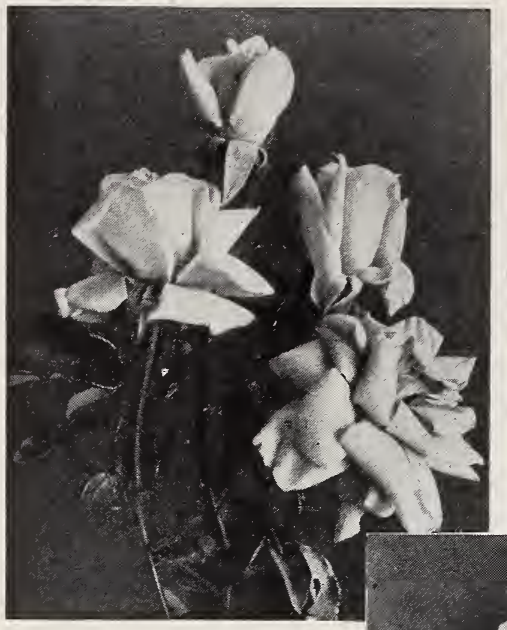

Bon Silene

Bridesmaid. (Tea.) Fine large full flowers, delightfully tea-scented, clear rose pink, with crimson shading. A good healthy grower, makes elegant buds, very handsome, and one of the best for cut flowers. The most popular pink forcing rose.

Captain Christy. (H. P.) A delicate shade of pale peach, deepening toward center to rosy crimson; very large flat flowers.

Catherine Mermet. (T.) Color clear shining pink, with delicately shaded amber and fawn center; large globular flowers, and very beautiful in bud. A good grower and free bloomer.

Cecil Brunner. (Pol.) Salmon pink with deep salmon center.

Cheshunt Hybrid. (H. T.) Ruby-crimson, changing to rich maroon; large, very double, full and perfect form; a strong grower.

Chromatella (Cloth of Gold). (C. N.) A splendid climber; clean, thrifty growth; color clear, bright yellow, very full and double and delightfully fragrant. Constant and profuse bloomer.

Clement Messier. (C. N.) White outer petals with beautiful shell pink at center; fine buds and open flowers; medium size, double and full; sweet tea scent.
Climbing Bridesmaid. (C. T.) Dark pink, very similar to Bridesmaid; finely formed in buds and open

Climbing Clothilde Soupert. (C. T.) Very similar to Clothilde Soupert, its parent. Flowers borne in clusters; large, round, flat form, with beautifully ricated petals; double, full and very fragrant; desirable variety.

Climbing Malmaison. (C. N.) Rich, creamy flesh, fine rose.

Climbing Marie Guillot. (C. T.) Beautiful creamy flowers, sometimes with pale yellow center. Strong grower, fine climber; profuse bloomer.

Climbing Wootton. (H. T.) Large, open flowers, beautifully formed; color bright magentared, passing to violetcrimson, richly shaded. Free flowering, strong climbing sort. Desirable.

Clothilde Soupert. (Pol.) Pinkish rose, amber or creamy yellow, delicately flushed silvery rose; sometimes both red and white flowers borne on the same stem. Blooms in clusters. Perfectly full and double and delightfully fragrant. A 


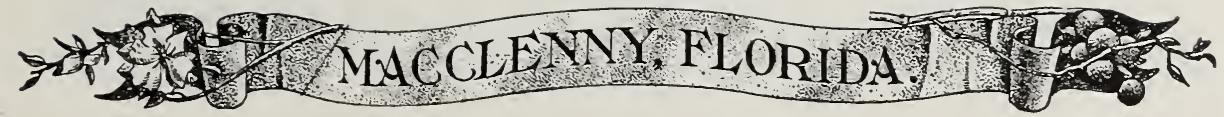

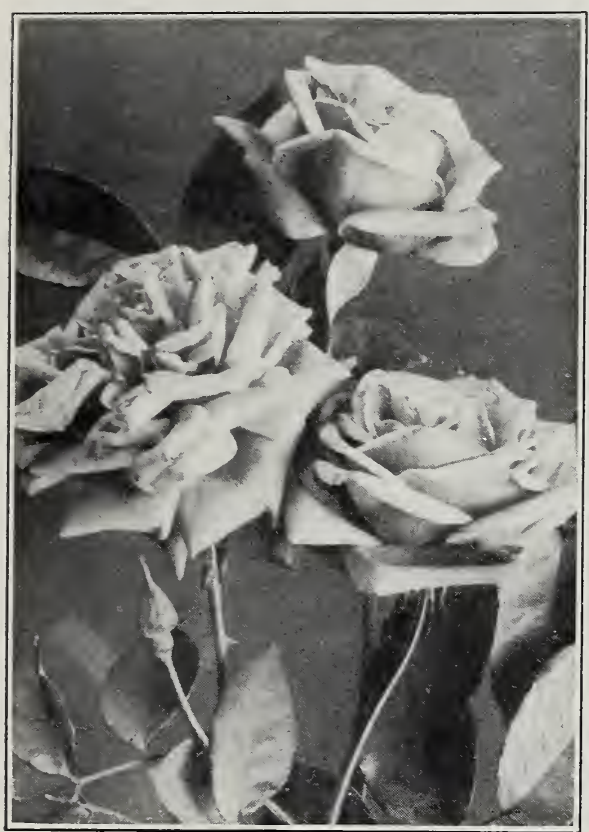

Mad. Lambard

Comtesse Eva Starhemberg. (T.) Long finely formed buds; open flowers, very double, full and regular. Color creamy yellow, shading to deeper yellow at center. Edges of petals tipped rose.

Devoniensis. (C. T.) A most magnificent climbing rose, often called the Magnolia rose on account of the snowy whiteness of the flowers, which generally show a delicate blush color at center. Delightfully fragrant. We consider this one of the finest roses in our collection. Can be grown as a bush rose by a little pruning. Very profuse and constant bloomer.

Crimson Rambler. (Pol.) A rampant climber, soon covers a trellis or veranda. Flowers are produced in great profusion in great panicles or trusses, each carrying 30 to 40 blooms. Individual flowers are about an inch to an inch and a half in diameter and brilliant crimson, which contrast finely with the dark green foliage.

Duchesse de Brabant. (T.) Delicate shell pink, tinged with carmine at edges of petals. A most beautiful color, quite distinct, does not fade. Unsurpassed by any pink rose. The flowers hold their form and color a long time after being cut. Strong grower, very profuse and constant bloomer. One of the most satisfactory.

Elise Boelle. (H. N.) White, delicately tinged with pink; medium size, full, beautiful, circular form; very sweet, a lovely rose.
Estelle Pradel. (C. N.) Pure white. Buds finely formed, flowers medium size, full and sweet. A good climber.

Etoile de France. ( $\mathrm{T}$ ) A very vigorous grower. Flowers very large, full, cupped: dark velvety crimson, center vivid cerise. A fine variety of recent introduction.

Etoile de Lyon. (T.) Large finely formed buds and flowers; very double, full and fragrant. Deep chrome yellow, deepening to pure golden yellow at the center. Except Marechal Niel, this is probably the finest yellow rose in the South. Very profuse and constant bloom. er. One of the best.

Fortune's Double Yellow. (C. T.) Salmon and sulphur yellow, edged rose; very beautiful and strikingly odd in coloring. Flowers large, single and open. A spring bloomer.

General Jacqueminot. (H. P.) Large globular flowers of a rich crimson-scarlet color.

General McArthur. (H. T.) Rose, as fragrant as a rose can be, has good sized flowers and blooms continuously. The bud when first opening is the brightest crimson scarlet, and the flower retains this perfect coloring until it drops its petals. Blooms continuously the whole season through. Its habit of growth is remarkably good, making strong, shapely plants that may be depended on for large flower shoots.

Gloire Lyonnaise. (H. P.) Pale salmon yellow, deepening toward center, very large and full; fragrant. Probably the only yellow hybrid perpetual. Strong grower.

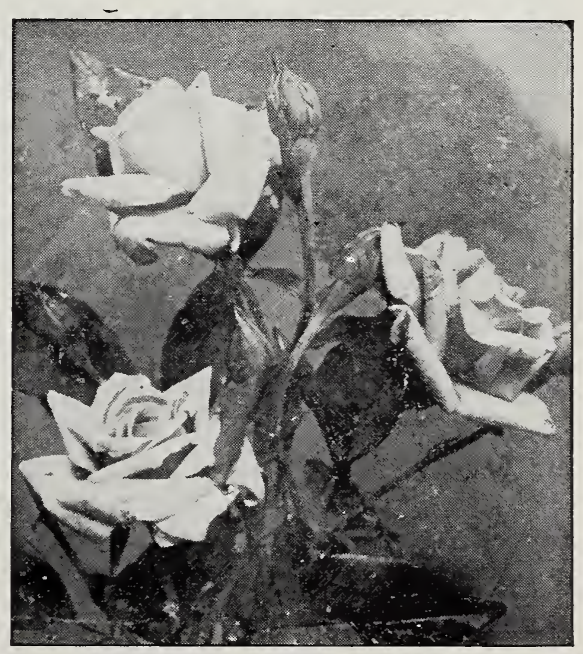

Reve D'Or 


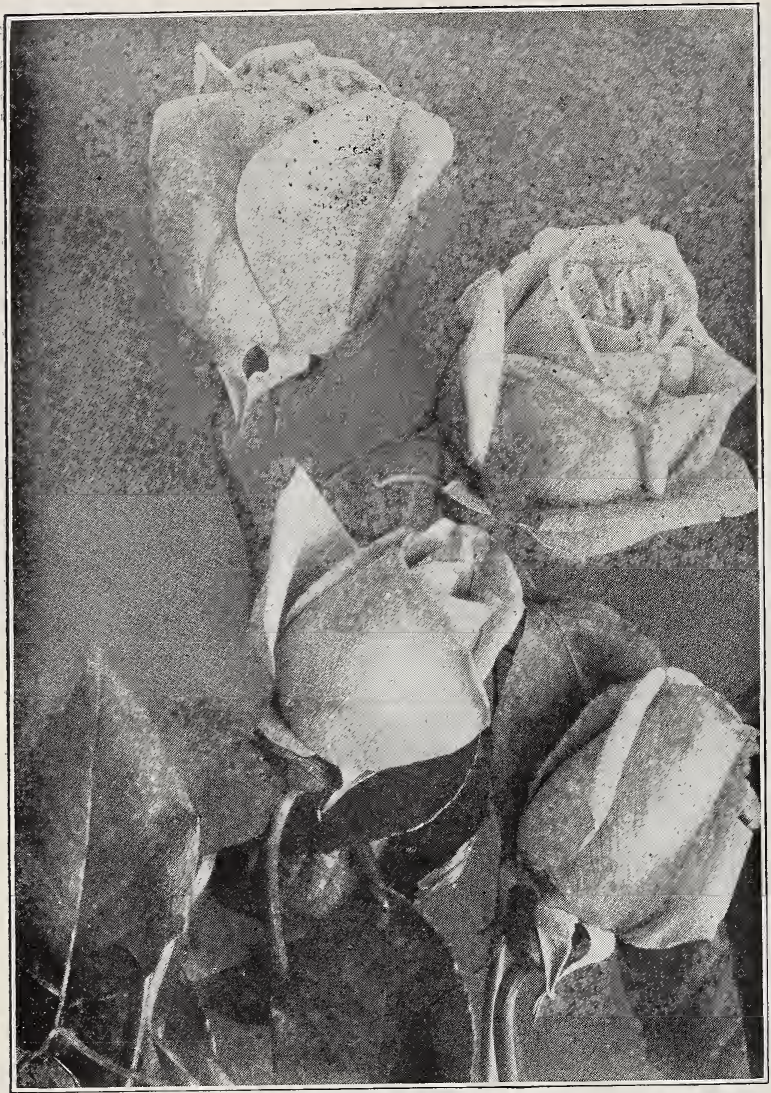

Marechal Niel

Gold of Ophir. (Ophire) Salmon yellow, shaded with coppery red One of the most beautiful of the climbing roses.

Heinrich Schultheis. (H. P.) Rosy pink color, fragrant; large and full.

Her Majesty. (H. P.) Very large, finely formed flowers of a lovely rosy pink, passing to clear flesh color, tinged with silvery rose.

Hermosa. (Bour.) Large, double, fragrant flowers in clusters; color clear rose.

Isabella Sprunt. (T.) Medium to large size; bright canary yellow color. Long, beautifully formed buds and delicately shaded flowers. One of the finest for cut flowers. Very vigorous and an exceedingly free and constant bloomer. Very satisfactory variety.

Ivory or White Golden Gate. (T.) A magnificent variety with extra large, full, finely formed flowers; buds long and beautiful. The color is rich, creamy white.
James Sprunt. (C. B.) A very fine dark cherry red rose; very full and double and delightfully fragrant. For cut flowers it is one of the best, for they hold in perfect condition a long time. A moderate climber and a very satisfactory bush. Strong grower and very constant and profuse bloomer. A fine variety.

John Hopper. (H. P.) Large and full; bright rose with carmine center. A stout, strong grower.

Jules Finger. (T.) Flowers rosy scarlet, shaded intense crimson; fragrant. Free bloomer.

Kaiserine Augusta Victoria. (H. T.) Very free blooming, strong growing variety. Flowers delicate creamy white, deliciously fragrant. An excellent variety for cut flowers.

Lamarque. (C. N.) Large delicate white flowers with sulphur center, very fragrant. Strong grower, good climber, very profuse bloomer at all seasons. An old but very satisfactory variety.

Le Detroit. (H. T.) Flowers of large size and form; Seautiful rose color delicately shaded pink. A free bloomer.

Letty Coles. (T.) Blush-colored flowers tinged with pale yellow; medium to large size and fine form, very fragrant. Strong grower.

Louis Philippe. (Beng.) One of the most satisfactory roses for grounds planting. An exceptionally profuse bloomer and there is seldom a time during the year when there are not quantities of flowers. A strong grower; makes a fine flowering hedge. Color rich, velvety crimson, full and double; not so desirable for cut flowers, for petals soon drop, but one of the most showy in a garden or grounds.

Louis Richard. (T.) Beautifully shaded and marbled coppery rose with deep red; quite distinct and pretty. Good grower and constant bloomer.

Mad. Alfred Carriere. (H. N.) White with bluish color at center.

Mad. Bravy. (T.) Large and full: creamy white; very fragrant. A profuse bloomer.

Mad. Caroline Kuster. (N.) Medium sized; pale yellow, tinged with rose. 

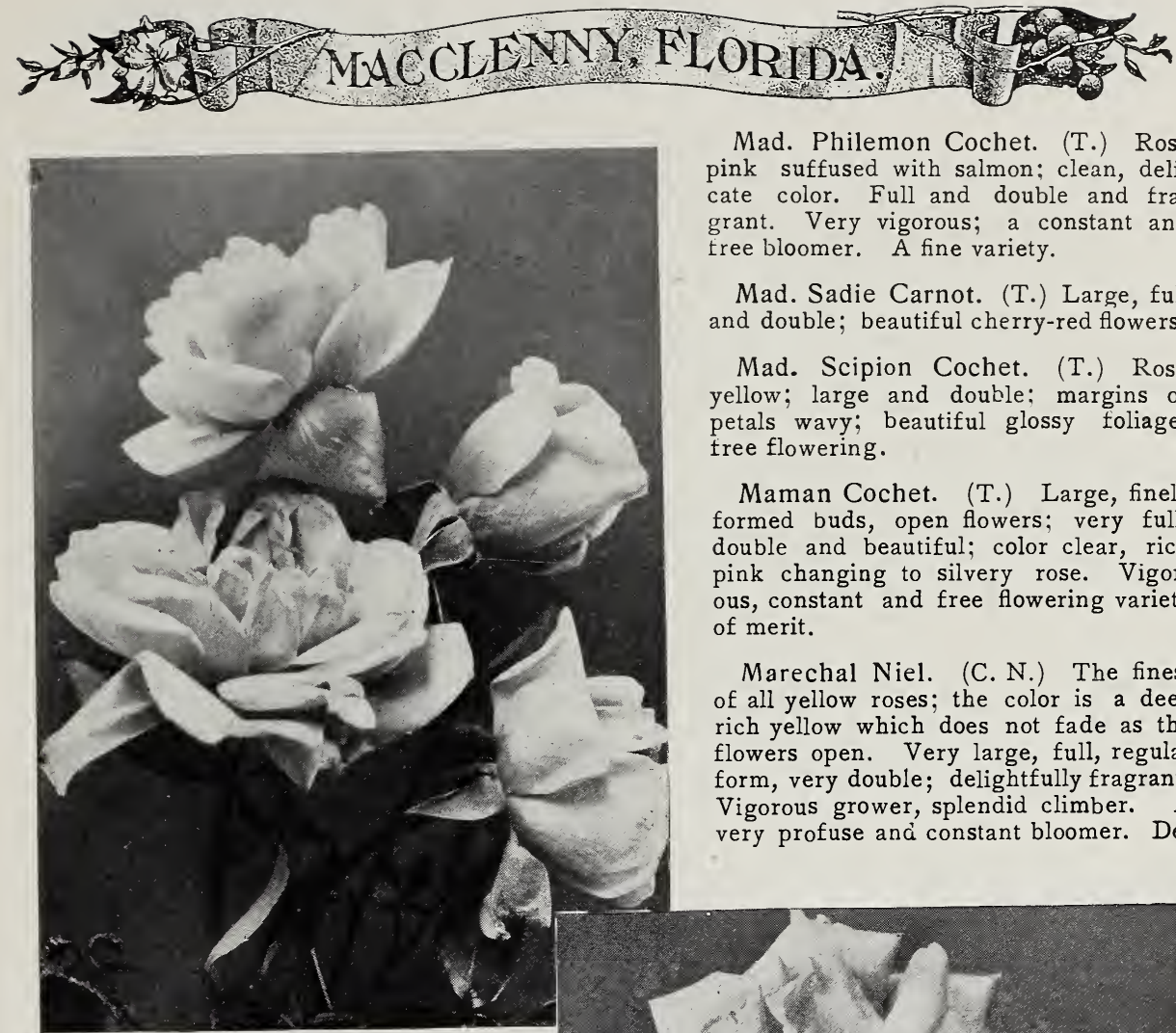

Mad. Philemon Cochet. (T.) Rosy pink suffused with salmon; clean, delicate color. Full and double and fragrant. Very vigorous; a constant and tree bloomer. A fine variety.

Mad. Sadie Carnot. (T.) Large, full and double; beautiful cherry-red flowers.

Mad. Scipion Cochet. (T.) Rosy yellow; large and double; margins of petals wavy; beautiful glossy foliage; tree flowering.

Maman Cochet. (T.) Large, finely formed buds, open flowers; very full, double and beautiful; color clear, rich pink changing to silvery rose. Vigorous, constant and free flowering variety of merit.

Marechal Niel. (C. N.) The finest of all yellow roses; the color is a deep rich yellow which does not fade as the flowers open. Very large, full, regular form, very double; delightfully fragrant. Vigorous grower, splendid climber. A very profuse aná constant bloomer. De-

Maurice Rouvier

Mad. de Vatry. (T.) Bright red, shaded with salmon, large, full and double. Fine form in bud and flower. A free and constant bloomer.

Mad. de Watteville. (T.) "The Tulip Rose." Flowers creamy yellow; richly colored with rosy blush; the petals are large and each one widely bordered with bright crimson; a striking appearance. Very fragrant. Profuse bloomer; free grower.

Mad. Jos. Schwartz. (T.) Large, globular Howers, very full and sweet; color pure white, the edges of petals tinged with carmine. The flowers have the exquisiteness and delicacy of its parent, Duchesse de Brabant. One of the most satisfactory here.

Mad. Lambard. (T.) Rosy salmon and rosy flesh; large, full and double and beautifully formed in buds and flowers. Very profuse and constant bloomer. One of the most satisfactory in our collection. Vigorous grower.

Mad. Camille. (T.) Rosy flesh, changing to rosy salmon. Large, double and full. Very pretty.

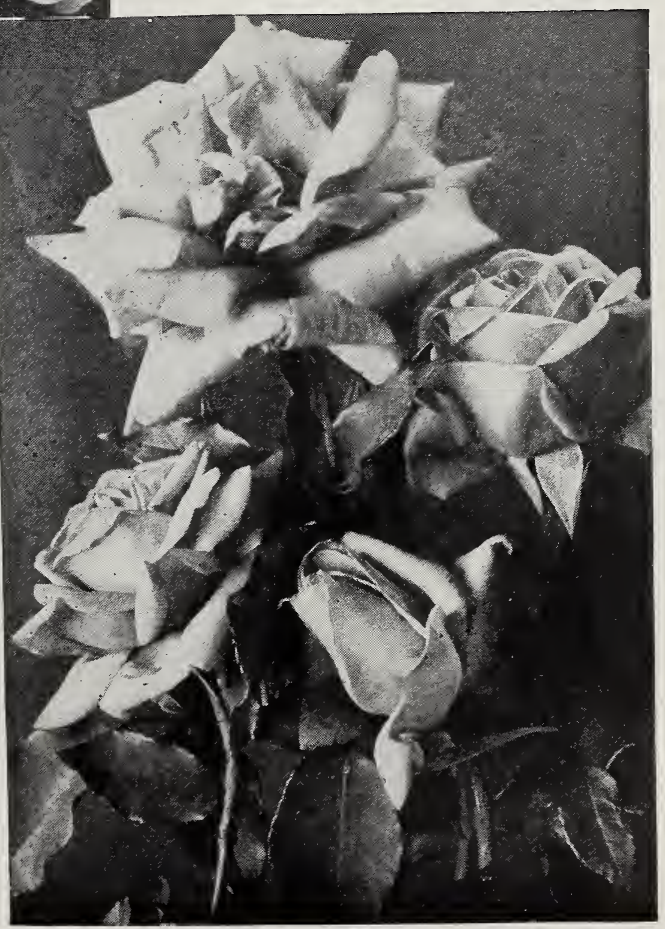

Minnie Francis

servedly the most popular rose in the South. No collection is complete without this splendid variety. 


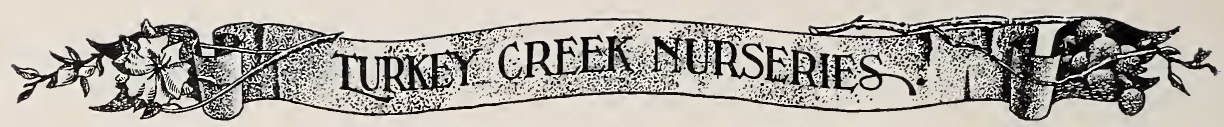

Margaret Dixon. (H. P.) Very large waxy white flowers, finely formed.

Marie Ducher. (T.) Light flesh to rosy pink, suffused with sulphur-yellow; reverse of petals silvery rose. A good grower and constant bloomer.

Marie Lambert. (T.) Pure white, medium sized, finely formed flowers. Very profuse and constant bloomer. One of the most satisfactory white roses.

Marie Van Houtte. (T.) Pale creamy yellow deepening toward center; outer petals often lined with rose. Sometimes both yellow and red roses are borne on the same stem; always beautifully formed and colored; very full and double, and fragrant. Very vigorous; profuse and constant bloomer. A most satisfactory variety.

Marshall P. Wilder. (H. P.) Large, perfectly formed flowers; color brilliant cherryred, shading to dark crimson. A clean healthy. grower and a remarkably constant bloomer for its class. Very desirable variety.

Maurice Rouvier. (T.) Pink, shaded with buff and crimson, with border of white. Strong grower and free bloomer.

Meteor. (H. T.) Brilliant velvety crimson, exceedingly rich and striking; both buds and flowers are large, elegantly formed, fully double. A constant bloomer.

Minnie Francis. (T.) Extra large, full and double; buds long and pointed; color fine chamois red, shaded with velvety crimson; very sweet fragrance. A profuse, constant bloomer and vigorous grower. Highly recommended.

Mrs. George Paul. (Bour.) Blush white with rosy pink shading: large open flowers like a camellia, broad thick petals. Quite distinct and beautiful.

Papa Gontier. (T.) A splendid crimson rose. Buds of immense size and exceptional beauty. Flowers large, bold and splendid substance. A fine variety.

Paul Neyron. (H. P.) One of the largest roses in existence; flowers deep rose color, very fragrant; free blooming.

Perle des Jardins. (Climbing.) Identical with Perle des Jardins, except that it is a vigorous climber. A grand addition to our roses. It will rank with the very best.

Prince Camille de Rohan. (H. P.) Deep velvety crimson, large, full.

Princess Alexandra. (H. T.) Very large and full, perfect cupped form, opens well; very free; creamy white. Kaiserin type.

Princess Bonnie. (H. T.) One of the finest and beautiful hardy ever-blooming roses. Color, bright rich crimson, exquisitely shaded

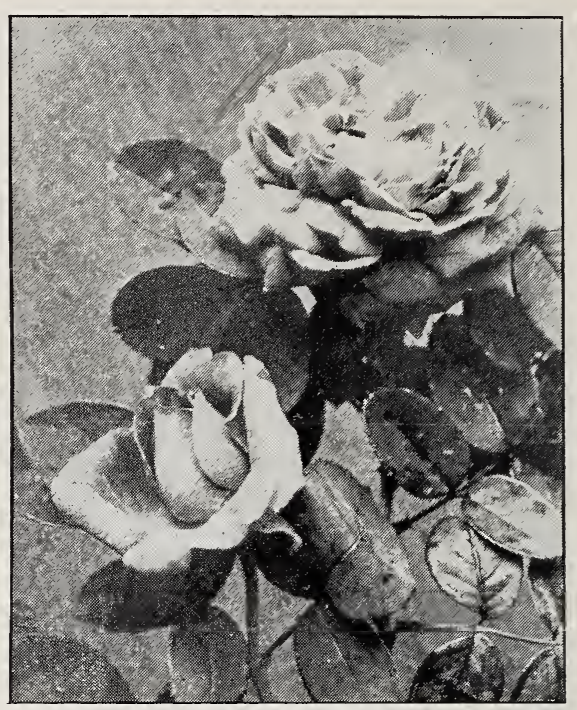

Marshall P. Wilder

and delightfully sweet. Noted for the size and beautiful form of both flowers and buds.

Queen. (T.) A grand, globular white rose of the most queenly rounded form, borne on large stems; a free grower and free bloomer. A sport from Souvenir d'un Ami.

Queen's Scarlet. (Beng.) Rich crimson, changing to light scarlet. A very distinct and striking shade. Very free-flowering.

Reine Marie Henriette. (C. T.) Bright cherry-red; does not fade or shade off into undesirable tints; large, double and finely formed; long beautiful buds; somewhat fragrant. A strong grower, profuse and constant bloomer. A fine rose, should be in every collection.

Reve d'Or (Climbing Safrano). (T.) Chamois-yellow; large; full; fragrant; free bloomer. An extra fine climbing rose.

Rhea Reid. (H. T.) One of the finest new roses. A cross of American Beauty with a red seedling. A vigorous and rapid grower. As large as American Beauty; very double and fragrant; continuous bloomer. Beautiful shade of red. An excellent rose in every way.

Safrano. (T.) Flowers a delicate tint of salmon and apricot yellow, which is always bright and clear, does not fade nor shade off into undesirable tints. One of the most exquisitely colored roses; very beautiful in bud. Vigorous grower and very profuse bloomer. A fine variety.

Seminole Queen. Beautiful, large, extra fine buds opening into a large double and 


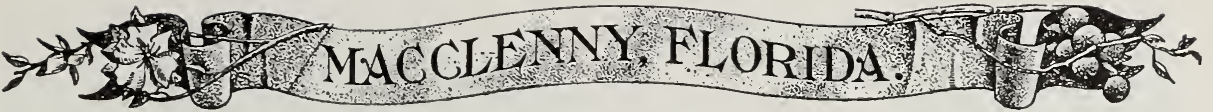

full rose pink. Bush a good grower and a heavy bloomer. A tea rose

Snowflake (White Hermosa). (T.) This variety is never out of bloom, and for a pure white bedding rose its equal is hard to find.

Solfaterre. (C. T.) Large and very double and exceedingly sweet tea scent; clear sulphur yellow. Strong climber, but can be grown as a bush or made into a fine flowering hedge. Growth and foliage quite similar to Marechal Niel. Exceptionally profuse and constant bloomer.

Souvenir de Leonnie Viennat. (T.) Color deep yellow, with amber in base, passing to rose color, reverse of petals silvery rose. Flowers large, and finely formed. Free bloomer.

Souvenir de Mad. Pernet. Silvery rose, shaded yellow; reverse of petals sometimes striped white. Medium sized, cup-shaped flowers.

Souvenir de Wootton. (H. T.) Bright magenta rose passing at base to violet crimson. Large, full and regular; thick leathery petals; delightfully fragrant.

Souvenir d'un Ami. (T.) Clear shining pink, sometimes shaded with carmine. Large finely formed flowers; semi-double. Free bloomer.
Sylphide. (T.) Large and double: color blush with fawn center. Very free flowering.

Victory. (H. P.) Very large, very full and double; color dark rich velvety crimson.

White Perle des Jardins. (T.) Pale yellow, deepening toward center; outer petals often tinged rose; sometimes both red and yellow flowers on same plant, but always beautiful: large, full, double and beautifully formed; fragrant. Very strong grower and constant and profuse bloomer. One of the most satisfactory.

White Maman Cochet. A sport from that grand sort, Maman Cochet, with which it is identical in every respect but color. It is a beautiful snow white, sometimes tinged with the faintest suggestion of blush. An extraordinary rose. Hardy with but slight protection.

Winnie Davis. (T.) Named for "The Daughter of the Confederacy." Color apricotpink, shading to flesh tint at base of petals; buds long and well formed; resembles a sunburst when fully open; strikingly beautiful. A strong grower and very free bloomer. A fine variety.

Zelia Pradel. (N.) Pure white, medium sized flowers; fine buds in clusters. Half climber, makes a fine bush. Strong grower; free bloomer.

\section{Shade and Ornamental Trees}

Box Elder. A fine, rapidgrowing variety, with handsome, light green foliage and spreading head; very hardy; excellent for avenues.

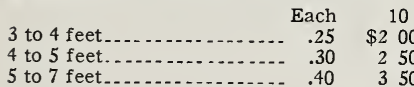

Camphor. (Cinnamomum Camphora.) A rapid growing evergreen tree of very symmetrical growth. Can be trained into an excellent shade tree; makes an exceptionally fine windbreak and is desirable as an ornamental. Hardy throughout the Gulf Coast country; thrives in almost any soil. Within the past two years the Department of Agriculture has made some very successful experiments in producing camphor gum from these trees in Florida and the officials who carried on these experiments are very enthusiastic over the possibilities of commercial camphor production on a large scale in the Gulf Coast country.

PRICES ON CAMPHOR TREES.

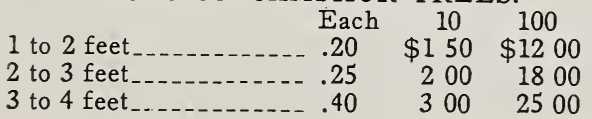

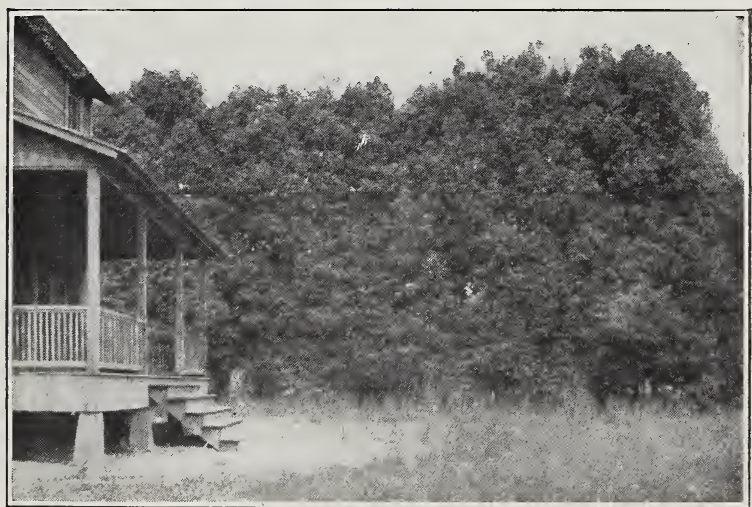

Camphor

A Fine Evergreen Shade Tree, an Excellent Wind-break: Being Extensively Planted Now for Commercial Camphor Gum Production.

$\begin{aligned} & \text { Rhamnus Catharticus, Common } \\ & \text { Each }\end{aligned}$
thorn.
2 to 3 feet, trans
3 to 4 feet, trans._._.

Catalpa Speciosa. A rank growing tree used largely in the West for railroad cross-ties, fence posts, etc., on account of the extreme durability of the wood. Makes an excellent shade in very short time. Blooms in June; blossoms white and about $2 \frac{1}{2}$ inches across. 


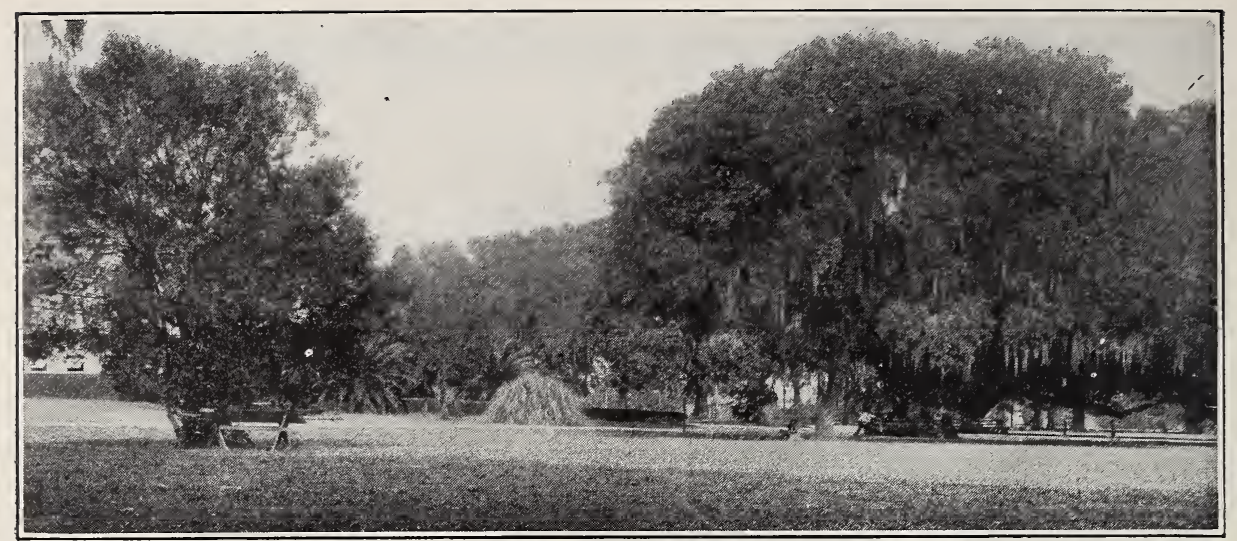

Grand Old Live Oaks

A Mighty Hard Tree to Beat for Shade and Ornamental Planting

PRICES ON CATALPA.

Each $\quad 10 \quad 100$

3 to 4 feet_._. $\quad .25 \quad \$ 200 \quad \$ 1500$

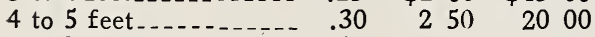

6 to 8 feet.......... $50 \quad 400 \quad 3000$

Carolina Poplar. Very quick growing shade tree. Very popular for street and avenue planting, as well as for grounds. Where a shade is wanted in the quickest possible time this is a very desirable deciduous tree.

Poplar Lombardy (P. Nigra Itulica). A straight, upright-growing tree of striking appearance. The leaves are small or medium sized, dark green with flattened petioles.

\section{PRICES ON CAROLINA AND LOMBARD} POPLAR.

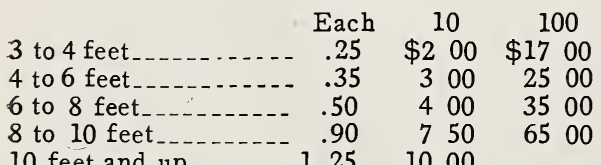

10 feet and up....- $125 \quad 1000$

Cottonwood. (Texas Cottonwood.) An extremely rapid growing deciduous shade tree; better in the South than Carolina Poplar. Forms a shapely top. Very desirable where a quick shade is wanted.

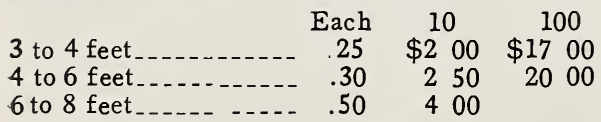

Cedrus Deodara. (Himalayan Cedar.) A very graceful tree somewhat resembling a fir; the short bluish green needles and unique form of growth makes it an exceptionally striking and beautiful tree. Rather slow growth, but attains immense size ultimately.

Each 10

2 to 3 feet_................. $\$ 600$

3 to 4 feet................ $00 \quad 800$

4 to 5 feet........................ $150 \quad 1200$

5 feet up............... $200 \quad 1800$

Red Cedar (Juniperus Virgina). A dark green tree with conical head and upright spreading branches. It grows rapidly and reaches a large size. It should be planted in a sunny exposure.

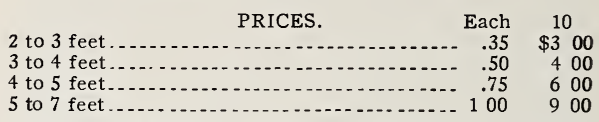

Cherry Laurel. (Prunus Caroliniana.) Small tree or large bush. Can be trained in almost any form. The foliage is very dark glossy green and exceptionally beautiful. One of the most desirable evergreens. Makes a fine hedge.

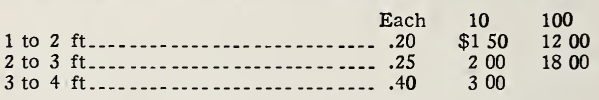

Cherry. The native wild Southern cherry. A rapid growing deciduous tree, very desirable for shade. Bright clean trunk and light green foliage. Some trees produce small black berries of rather acid but agreeable flavor.

\section{PRICES-COLLECTED SPECIMENS.}

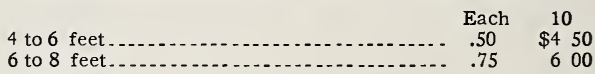

Black Gum. (Nyssa Sylvatica.) A native deciduous tree of exceptional beauty. Rapid grower, forms a symmetrical well rounded top. Prefers a moist soil, but does well on high land. Foliage light green in early spring, dark green and very dense during summer, and in late autumn turns flaming scarlet. Attains large size.

\section{PRICES-COLLECTED SPECIMENS.}

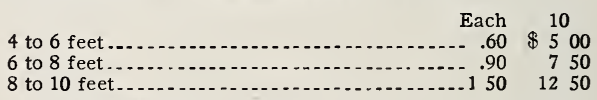

Calycanthus. (Sweet shrub, Butneria florida.) An old-fashioned, strong, upright shrub, which produces chocolate-colored, very fragrant flowers.

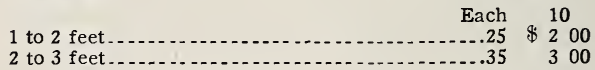

Viridis. (Green Ash.) An extra fine rapidgrowing variety with light green foliage; very desirable when a quick shade is wanted. 


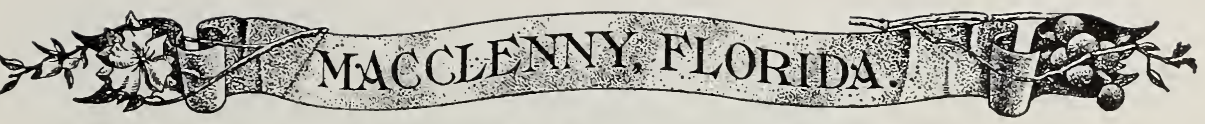

PRICES ON VIRIDIS.

$\begin{array}{llr}2 \text { to } 3 \text { feet.......... } & .25 & \$ 20 \\ 3 \text { to } 4 \text { feet.......... } & .35 & 300 \\ 4 \text { to } 5 \text { feet.......... } & .50 & 40\end{array}$

Locust, Black. ( $R$. Pseudacia.) M ed i u m sized tree with feathery foliage and drooping racemes of very fragrant pea shaped flowers.

PRICES-BLACK LOCUST.

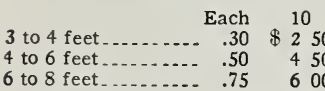

to 8 feet $-75 \quad 600$

Red Bud. (Cercis Canadensis.) A small tree 20 to 30 feet high, with rounded, handsome leaves, producing an abundance of rosy pink flowers in early sping.

Sweet Gum. (Liquidambar Styraciflua.) Native rapid growing deciduous tree; somewhat pyramidal in form of growth. Does well in either moist or dry soils. Foliage resembles that of scarlet maple in outline, but of lighter green color; turns dark crimson in late autumn. Bark on trunk and limbs often corky. Makes a fine shade tree; very ornamental. Attains large size.

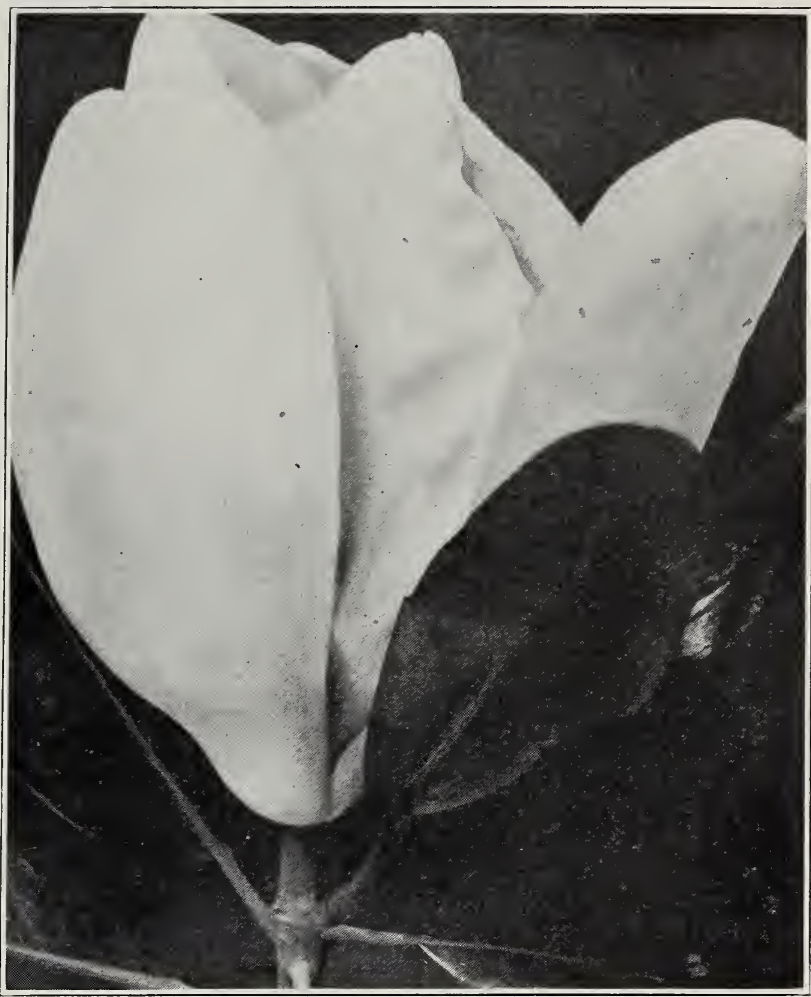

Magnolia Grandiflora

A Magnificent Evergreen Flowering Tree
PRICES-COLLECTED SPECIMENS.

\section{Each $\quad 10$}

2 to 3 feet .................... $\$ 250$

3 to 4 feet

4 to 6 feet.......................

6 to 8 feet................ $100 \quad 900$

8 to 10 feet............... $150 \quad 1200$

American Holly. (Ilex Opaca.) A dark green, crinkly, saw-edge foliage tree of evergreen habit. Produces a profusion of bright red berries, forming a contrast of color-dark green and brilliant red-that is very pleasing; makes one think of Christmas time. Very useful for decorative purposes.

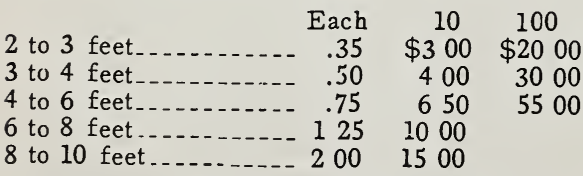

Magnolia Grandiflora. A magnificent broadleaved evergreen of our native forests. Foliage very dark glossy green. Trees form beautiful tops and make unusually fine shade trees. The flowers, which are very large, are of snowy whiteness and are delightfully fragrant.

PRICES ON MAGNOLIA GRANDIFLORA.

Each 10

1 to 2 feet............... 40 30

2 to 3 feet.................... 50 450

3 to 4 feet......... 650

4 to 5 feet................. $100 \quad 900$

5 to 7 feet.......... 1200

Magnolia Glauca. (Sweet Bay.) An attractive shrub or small tree, evergreen; leaves dark green, flowers about two inches across and very fragrant. Desirable ornamental. Easily grown.

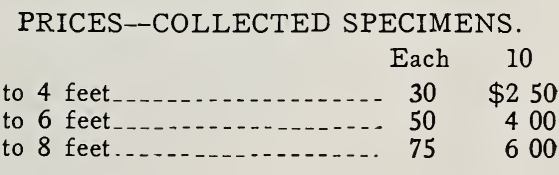

Magnolia Bay. (Gordonia Lasianthus.) Very similar to Magnolia Glauca, ex- 
cept flowers are about 4 to 6 inches across; quite similar to Magnolia Grandiflora, fragrant; very fine ornamental.

PRICES-COLLECTED SPECIMENS.
Each

Magnolia Virginiana. (Loblolly Bay.) A fine tree, closely resembling Magnolia Grandiflora in growth, foliage and large showy white flowers.

\section{PRICES-COLLECTED SPECIMENS.} Each $\quad 10$

3 to 4 feet.................... 30 $\$ 250$

4 to 6 feet...................... 400 6 to 8 feet .75

600

Live Oak. (Quercus Virginiuna.) A stately evergreen oak, native of the South. Small dark green foliage. Of moderate growth, but well worthy of first place in avenue, street and grounds planting. We consider it one of the finest shade trees in existence.

\begin{tabular}{|c|c|c|}
\hline $\begin{array}{l}\text { PRICES-COLLECTED SPECIMENS. } \\
3 \text { to } 4 \text { feet }\end{array}$ & Each & $\begin{array}{c}10 \\
\$+00\end{array}$ \\
\hline $\begin{array}{l}3 \text { to } 4 \text { feet... } \\
4 \text { to } 6 \text { feet... }\end{array}$ & & 500 \\
\hline $6 \mathrm{t}, 8$ feet... & 100 & 900 \\
\hline 8 to 10 feet. & 200 & 1500 \\
\hline
\end{tabular}

Water Oak. (Quercus nigra acquatica.) One of the most rapid growing oaks. Forms a beautiful well rounded head; attains large size. Deciduous for a short time during the winter, but very handsome when in foliage. Leaves medium size, triangular.

PRICES-COLLECTED SPECIMENS. Each 10

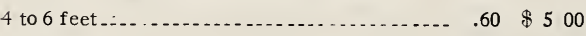
6 to 8 feet................................ $100 \quad 900$ 8 to 10 feet................................ $200 \quad 1500$

Willow-Leaved Oak. (Quercus phellos.) Rapid growing oak, semi-deciduous. One of the handsomest and most symmetrical. Attains large size. Foliage small, narrow, long; dark green. A native oak often called water oak. Makes a fine shade tree; much used for park, avenue and grounds planting.

PRICES-COLLECTED SPECIMENS. Each 10 3 to 4 feet.............. .45 $\$ 400$

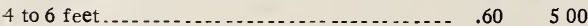
6 to 8 feet................................. $100 \quad 900$ 8 to 10 feet............................... $200 \quad 1500$

Sassafras. An ornamental deciduous tree, native of this country. Forms a symmetrical top with slight pruning. Very rapid grower. Resembles to a slight extent the camphor tree. Makes a desirable ornamental shade tree. Tea made from the roots of sassafras has a delightful flavor. We think so much of sassafras as an ornamental tree that we have it growing on our own grounds.

Each 10

3 to 4 feet, straight trees_._._. . $20 \quad \$ 175$

4 to 6 feet, straight trees_._. . .25 200

6 to 8 feet, partly branched..... .40 350

Sycamore. (Platinus orcidentalis.) A popular shade tree. Grows rapidly and is of spreading habit. Does well on high or low places. One of the most desirable shade trees. Valuable for street planting.

Each $\quad 10 \quad 100$

3 to $4 \mathrm{ft}$., straight trees_. $.25 \quad \$ 200 \quad \$ 1700$ 4 to $6 \mathrm{ft}$., straight trees_. $.35 \quad 300 \quad 2500$ 6 to $8 \mathrm{ft}$.,partly branched $.50 \quad 400 \quad 3500$ 8 to $10 \mathrm{ft}$., very fine

Texas Umbrella. (Melia azedarach umbraculiformis.) An extremely rapid growing shade tree. Forms a beautiful, rounded, umbrellashaped top. Foliage very dense. For a quick shade there is nothing better. Trees are remarkably handsome when in foliage, which is most of the year.

PRICES ON TEXAS UMBRELLA.

\begin{tabular}{|c|c|c|}
\hline Each & 10 & 100 \\
\hline to 3 feet.... & $\$ 200$ & $\$ 1500$ \\
\hline to 4 feet & 250 & 2000 \\
\hline to 6 feet & 350 & 3000 \\
\hline ft. up, branched, fine .80 & 650 & \\
\hline
\end{tabular}

Tulip Tree. (Liriodendron tulikifera.) "Yellow Poplar." A very peculiarly shaped foliaged tree; leaves large, notched on each side and square on end, light green. Trunk clean, straight, with broad spreading branches. Beautiful well rounded tops, form fine shade trees. Flowers are large, greenish yellow, blotched with orange, similar in shape to the tulip from which it derives its name. An unusually attractive and satisfactory tree.

PRICES-TRANSPLANTED SPECIMENS.

\begin{tabular}{|c|c|c|}
\hline Each & 10 & 100 \\
\hline to 3 feet............... & $\$ 250$ & $\$ 2000$ \\
\hline to 4 feet & 350 & 3000 \\
\hline 4 to 6 feet. & 450 & 4000 \\
\hline 5 to 8 feet & 600 & 5000 \\
\hline
\end{tabular}




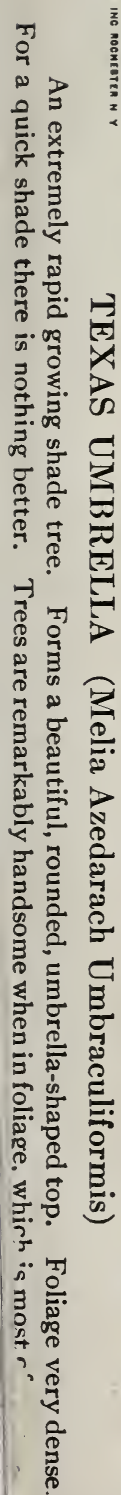

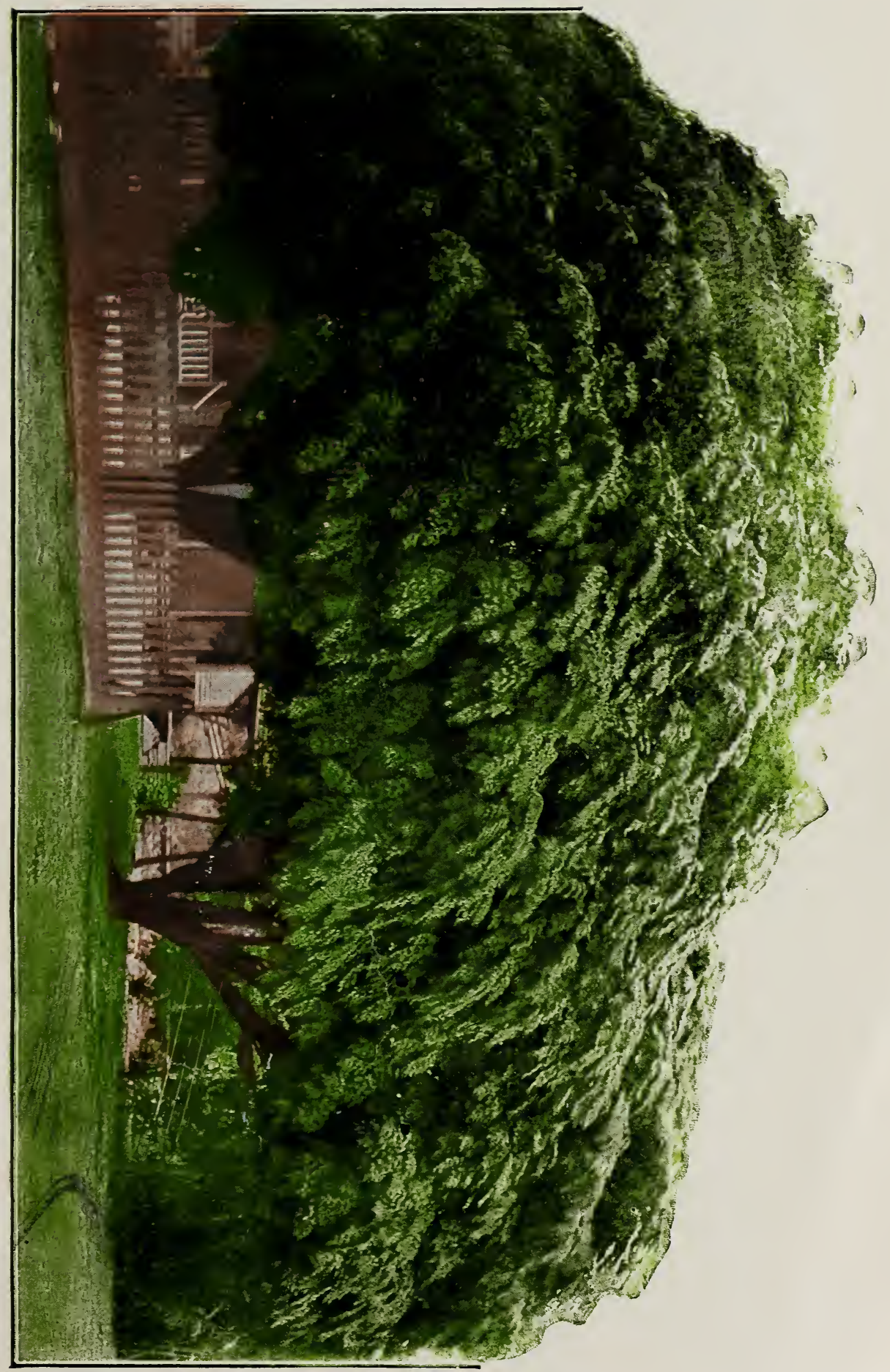



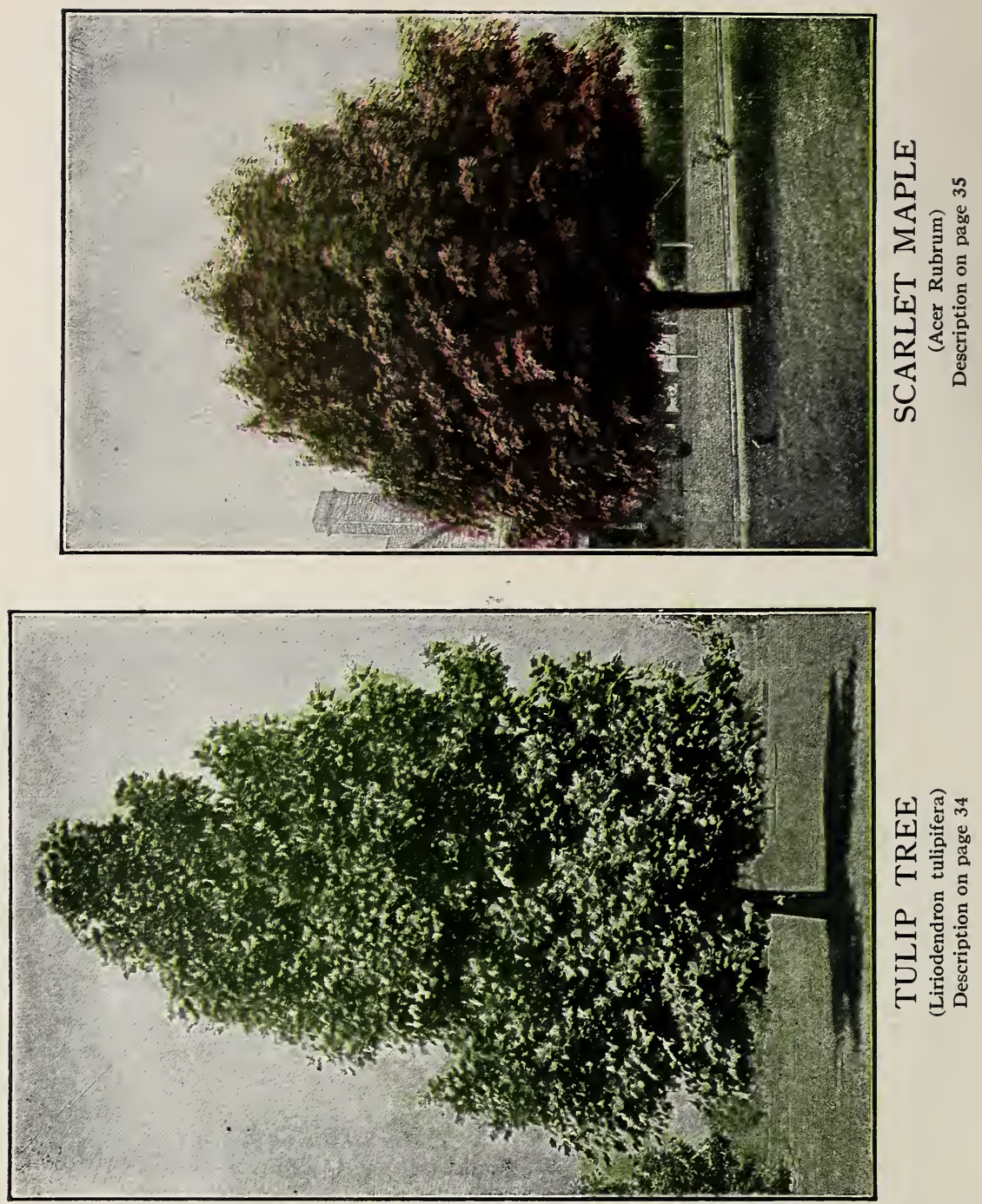

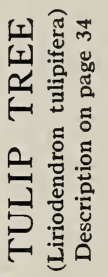

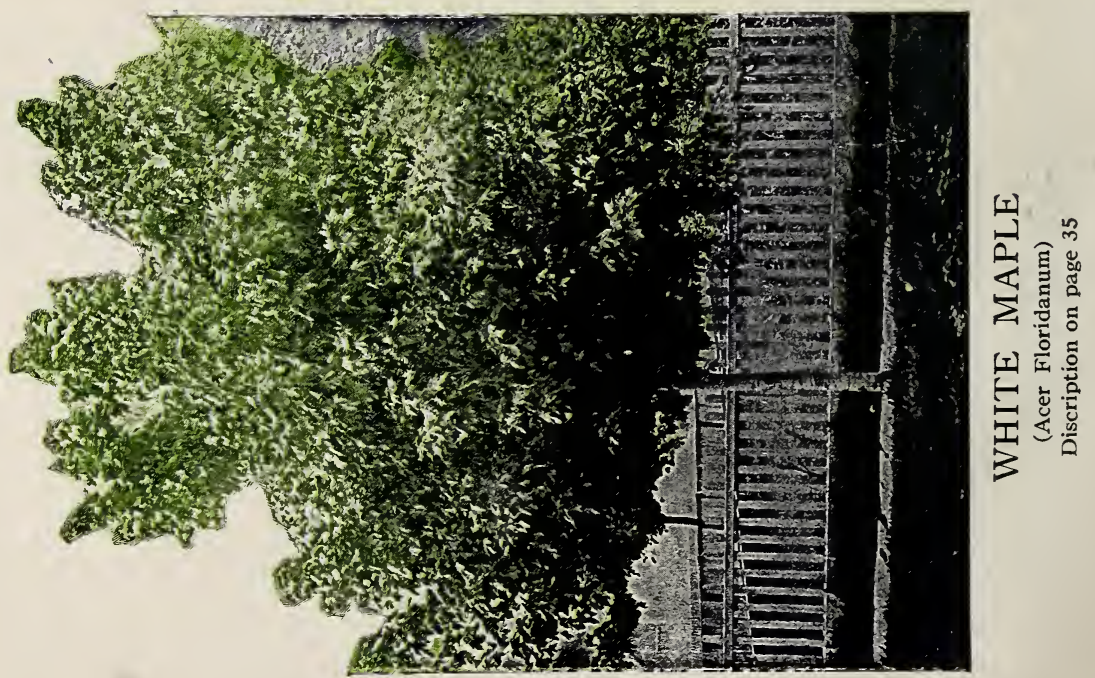




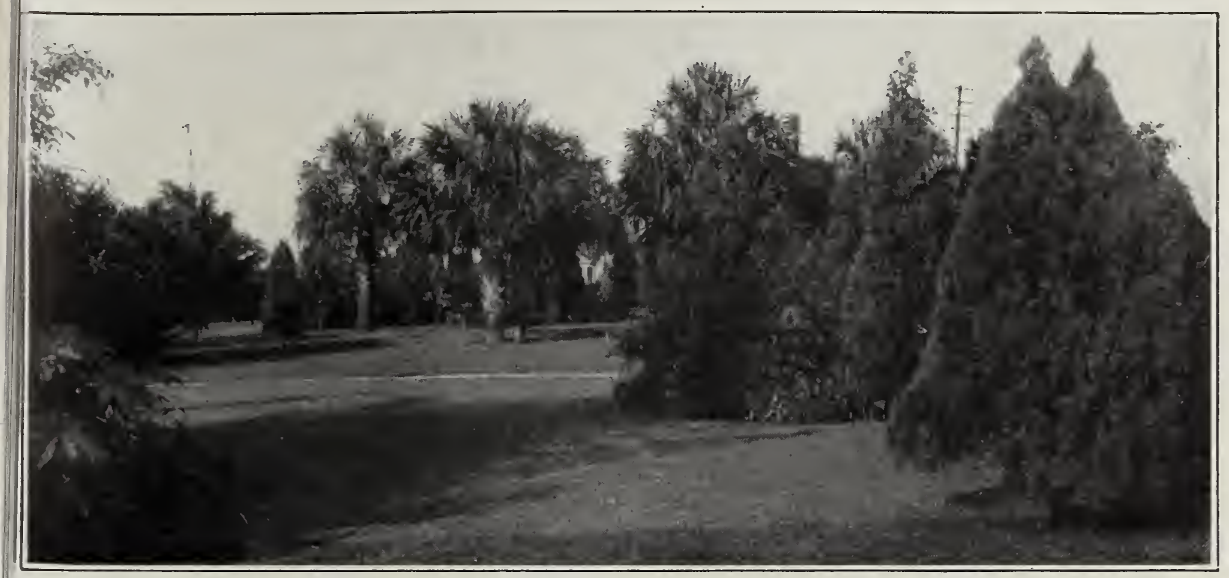

An Effective Landscape Planting

Showing Arborvitae and Palmetto to Advantage

Scarlet Maple. (Acer Rubrum.) An exceptionally fine native deciduous tree of fairly rapid growth; attains large size. Its brilliant red samaras (flowers) are the first in the spring, and these are immediately followed by delicately traced, lobed foliage of brilliant scarlet color, which gives an otherwise rather drear landscape a striking touch of color. During the summer the foliage turns light green, but the young shoots are always tinged with scarlet, and in the late autumn the trees turn dark crimson. I One of the finest ornamental shade trees for Southern as well as Northern planting.
PRICES-TRANSPLANTED SPECIMENS.

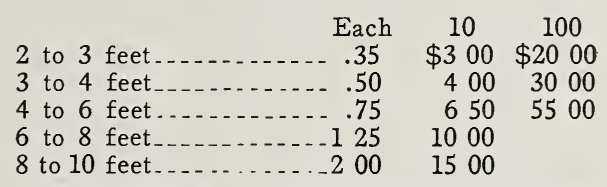

White Maple. (Acer Floridanum.) A native Southern tree, quite handsome and unique. Foliage dark glossy green above and almost snowy white on under side. Tree makes a fine shade, and is very odd.

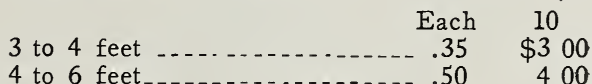

\section{Conifers and Flowering Shrubs and Trees}

Arborvitae, or Biota. Beautiful evergreens, usually very symmetrical. Desirable for lawn, park or grounds planting. Make beautiful hedges and require no pruning.

Biota aurea nana. Cone-shaped, well rounded symmetrical heads; beautiful light greenish yellow foliage. One of the finest. Especially desirable for lawns or gardens or for lining walks.

\section{PRICES.}

1 to $11 / 2$ feet ................... .40

$11 / 2$ to 2 feet.....................

2 to 3 feet .................. 100

10 $\$ 350$ 600 900

Biota pyramidalis. Upright pyramidal growth. Desirable for ends of walks or hedges, or for planting as single specimens.
PRICES.

\begin{tabular}{|c|c|}
\hline Each & 10 \\
\hline 2 feet & $\$ 300$ \\
\hline 3 to 4 feet & 700 \\
\hline 4 to 5 feet.......... 150 & 1200 \\
\hline
\end{tabular}

Biota orientalis. A rather open, somewhat coarse arborvitae, but a rapid grower and attains large size. Suitable for edges of woodlands as well as for grounds planting.

\section{PRICES.}

Each

1 to 2 feet_...................... 25

2 to 3 feet -35

3 to 4 feet

4 to 5 feet 


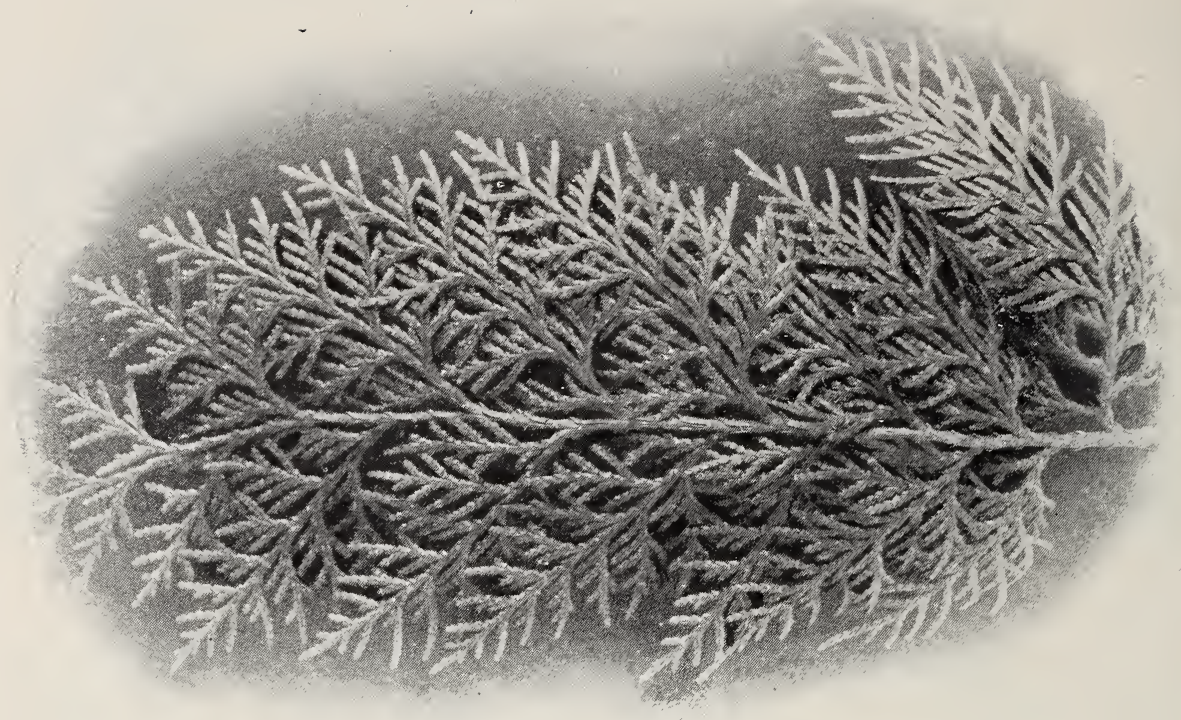

Biota Rosedale. Very compact symmetrical, rounded heads; foliage is of a dark bluish green cast, which gives this variety a distinct and unique appearance. Cne of the finest.

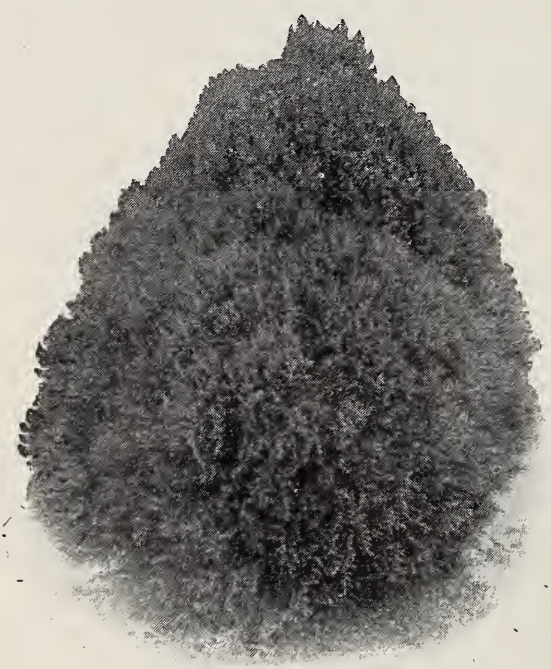

Biota Rosedale

One of the Finest of Arborvitaes

PRICES. Each

1 to $11 / 2$ feet

$11 / 2$ to 2 feet................... 40

2 to 3 feet...........................

3 to 4 feet -100

4 to 5 feet, very fine
Biota Compacta. A compact symmetrical variety which attains considerable size. Desirable.

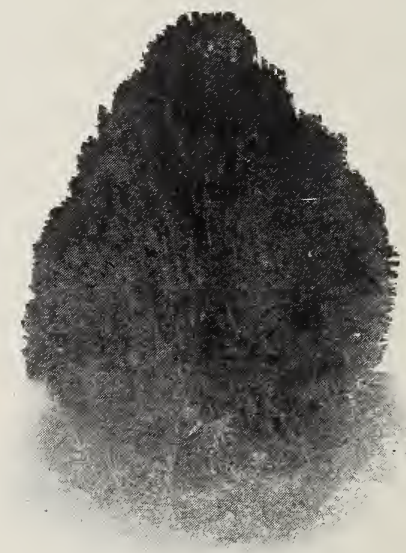

Biota Compacta

A Very Symmetrical Compact Variety

\section{PRICES. Each 10}

1 to 2 feet.................. $\$ 5$ \$300

2 to 3 feet ................. $50 \quad 400$

3 to 4 feet............... $00 \quad 800$

Retinospora plumosa. (Japanese Cypress.) A rapid growing tree with beautiful plume-like foliage, rather spreading habit, quite distinct and attractive for grounds or parks planting. 

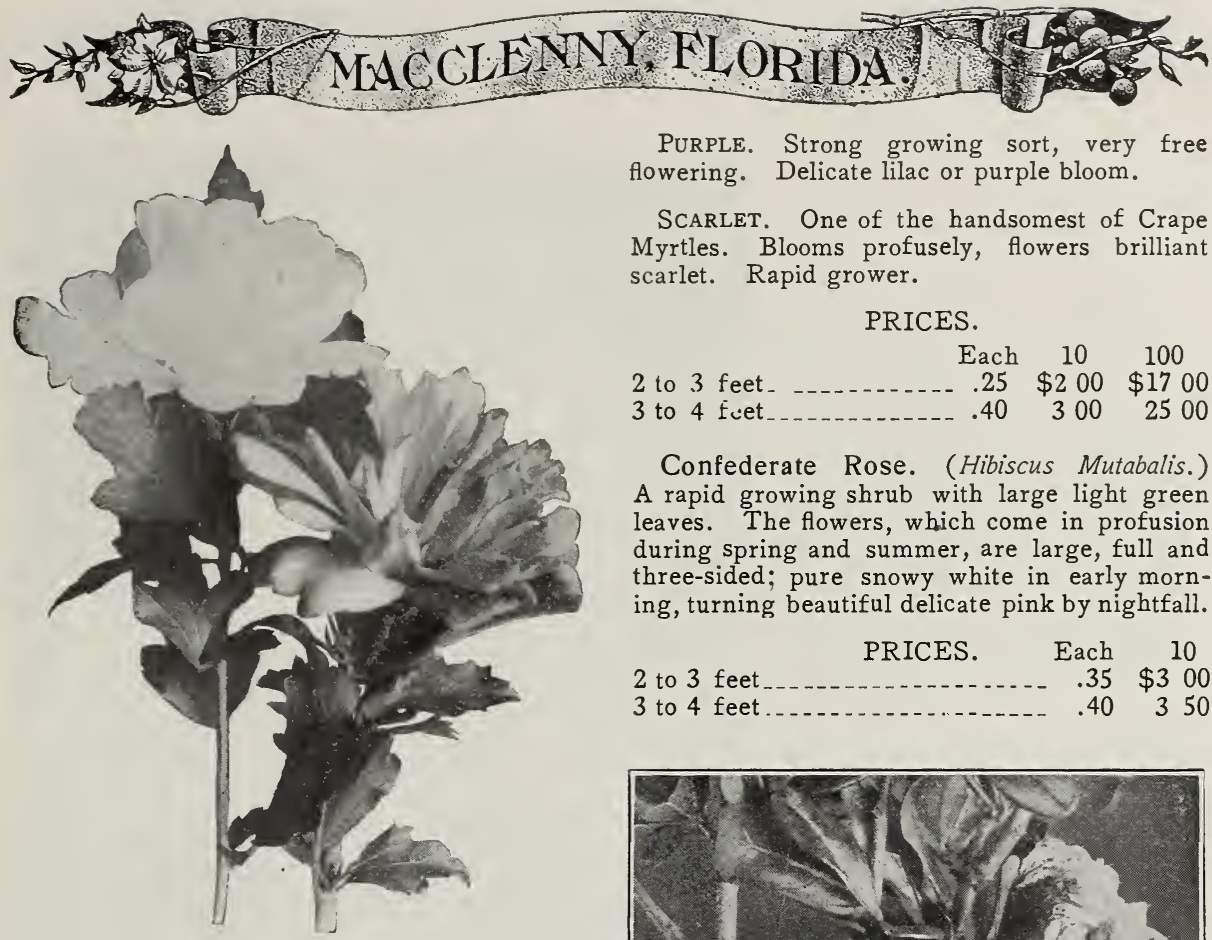

PURPLE. Strong growing sort, very free flowering. Delicate lilac or purple bloom.

SCARLET. One of the handsomest of Crape Myrtles. Blooms profusely, flowers brilliant scarlet. Rapid grower.

\section{PRICES.}

$$
\text { Each } \quad 10 \quad 100
$$

2 to 3 feet

$.25 \$ 200 \quad \$ 1700$

3 to 4 fiet

Confederate Rose. (Hibiscus Mutabalis.) A rapid growing shrub with large light green leaves. The flowers, which come in profusion during spring and summer, are large, full and three-sided; pure snowy white in early morning, turning beautiful delicate pink by nightfall.

$\begin{array}{rrrr}2 & \text { PRICES. } & \text { Each } & 10 \\ 3 \text { to } 3 \text { feet } 4 \text { feet.... } & .35 & \$ 300 \\ \text { to } & & 40 & 350\end{array}$

Althea Alba and Rubra

A Couple of Very Satisfactory Flowering Shrubs

\section{PRICES}

$$
\text { Each }
$$

2 to 3 feet

.35

3 to 4 feet

.50

4 to 5 feet.................. 100

Althea. (Rose of Sharon.) Flowering shrub of fine appearance and showy flowers. They are heavy bloomers; oftentimes the plants are a mass of red, white and blue flowers. Attractive for grounds or park planting. We have in stock Amplissima, double dark red; Boule de fen, double bright red; Carnea plena, semidouble flesh; Colestis, single blue; Duchess de Brabant, double light red; Monstrosus, double white; Rubis, single red; Speciosa, double flesh white; Totus Albus, single white.

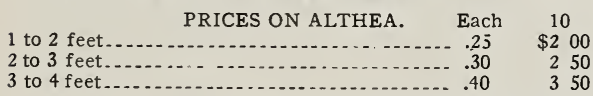

Cape Jessamine. (Gardenia fiorida.) Evergreen shrub with dark glossy green foliage. Very free flowering. Flowers pure white and very fragrant. Quite ornamental.

$$
\text { PRICES. Each }
$$

6 to 12 inches . . . . . . . . . . 20

1 to 2 feet

Crape Myrtle. (Lagerstroemiu Indica.) Free flowering deciduous shrubs or small trees. Flowers are produced in great panicles or trusses, and are delicately fringed. Make fine flowering hedges. We have in stock purple and scarlet.

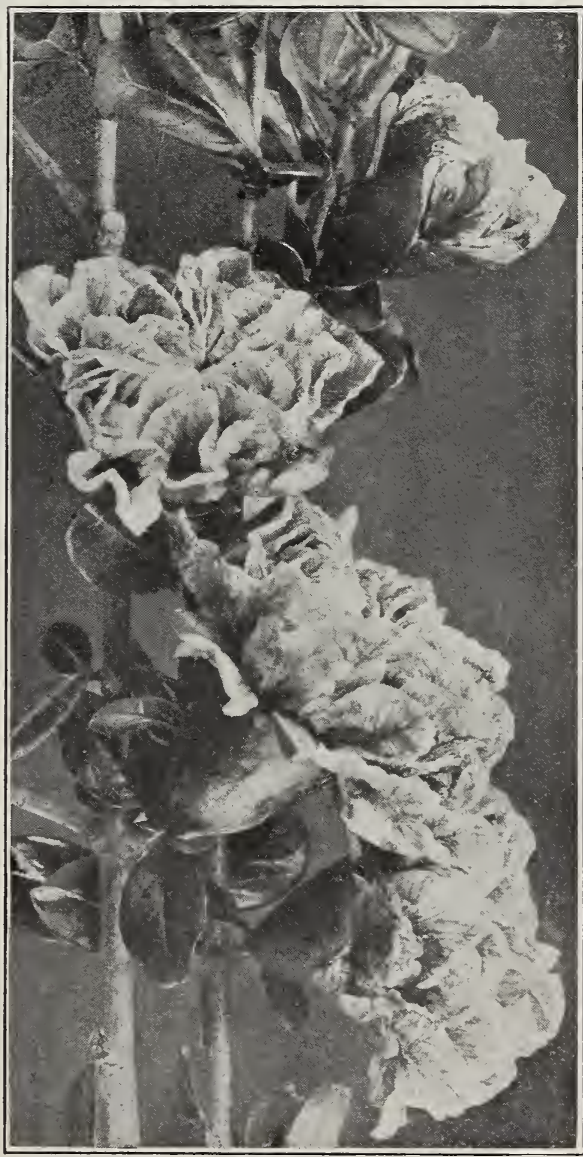

Double Blooming Pomegranate.-(See page 38.) Quite unique and exceptionally pretty 


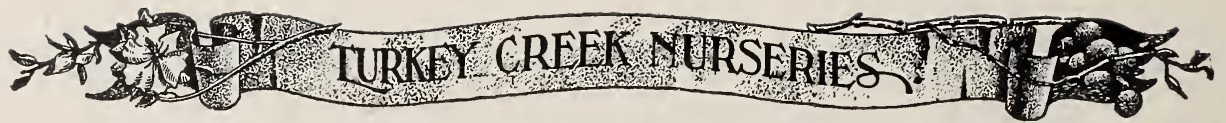

Kumquats. Small trees or large shrubs, which bloom freely during summer and are loaded in fall with small yellow edible fruits. See further description and prices in fruits section of this catalogue.

Dogwood. (Cornus rilorida.) A small tree with spreading bushy top and bright green leaves. The flowers, with their large white bracts, appearing in spring before the leaves, makes the Dogwood one of the most strikingly handsome trees. The fruit ripens in autumn and is bright scarlet in color.

Dogwood, Red. A stronggrowing shrub, with clusters of fine white flowers, the stem and branches turning blood-red in winter.

PRICES ON DOGWOOD. Each 10 2 to 3 feet.................30 \$2 50

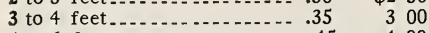
4 to 6 feet................. 4500

Double Flowering Pomegranate. A beautiful shrub with dark green foliage and strikingly handsome double flowers of a reddish color, sometimes variegated.

PRICES. Each 10

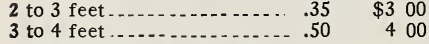

Euonymus J ap onica. A handsome evergreen shrub of dense upright habit. Native of Japan. Leaves dark lustrous green, holding their brilliancy and attractiveness throughout the winter. A grand plant for single specimens on the lawn, either in sun or in partial shade as tub plants for decorating cool rooms and corridors.

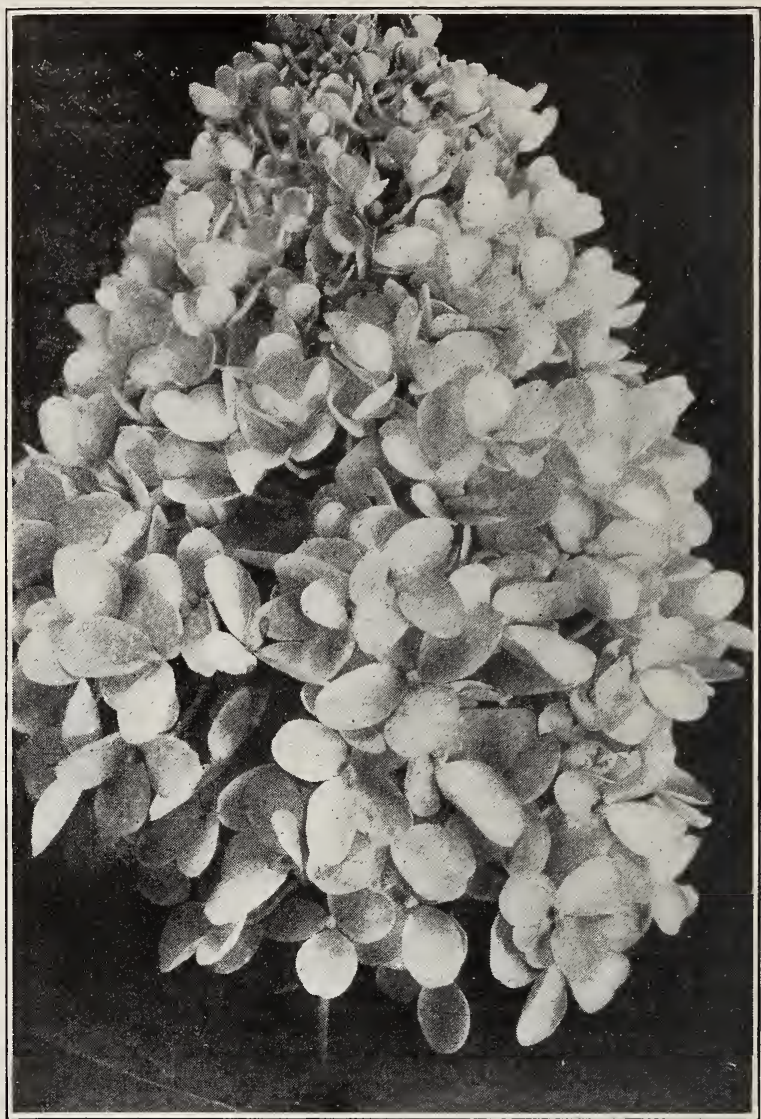

Hydrangea Paniculata Grandiflora

One of the Most Showy and Gorgeous Flowering Plants-Everybody Likes It

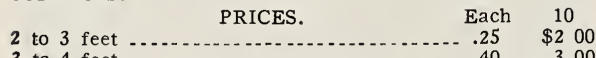

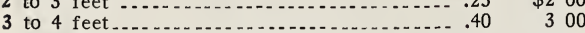

Laurel. A native wild shrub with dark green foliage, looks something like Cherry Laurel, but even more attractive. Can be easily trained into almost any desired form. Makes an excellent hedge. Flowers small and white, but quite pretty. PRICES-COLLECTED SPECIMENS.

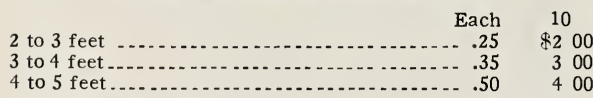

Hydrangea Paniculata Grandiflora. One of the most showy of ornamental plants. Flowers very large panicles, pure snowy white; blooms profusely. Plants easily grown, strong and vigorous. A very satisfactory plant. We know you will like it. Perfectly hardy in the South.

PRICES ON HYDRANGEA. Each 10

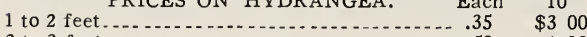

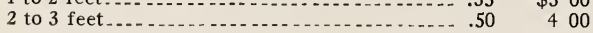

Japan Quince. (Cydonia Japonica Cardinalis.) A thorny shrub with dark green foliage, which, however, drops during the fall. In the spring the limbs become nearly covered with brilliant crimson flowers resembling peach blossoms in size, shape and manner of coming from stems. One of the first plants to bloom in spring. Strikingly beautiful when in bloom.

\section{PRICES ON JAPAN QUINCE.}

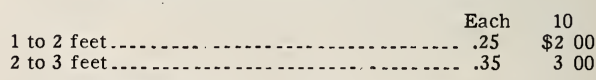

Japan Tea Plant. (Camellia Thea.) The genuine tea plant from which the tea of commerce is produced. Grows successfully in the Southern States, and with but slight trouble one can produce his own tea, either green or black. In fact tea growing on a commercial basis is being quite extensively and successfully carried on in South Carolina. There seems to be good prospects for commercial tea growing 


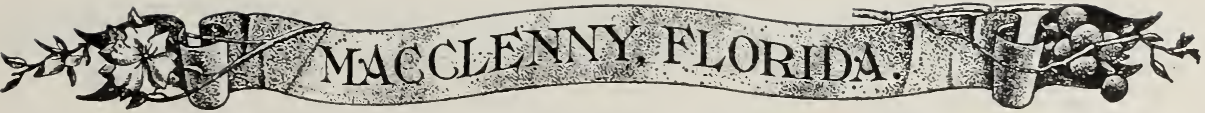

in many localities of the South. The plant is an evergreen, and quite ornamental. Produces quantities of white flowers about $1 \frac{1}{2}$ inches across, fragrant.

PRICES ON TEA PLANTS.

$$
\text { Each }
$$

1 to 2 feet.................... 40

2 to 3 feet........................

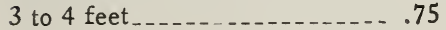

Philadelphus Laxus. One of the Mock Orange family. A strong growing bush which produces a mass of pure snowy white flowers in spring. Flowers about an inch across. Very ornamental.

PRICES ON PHILADELPHUS LAXUS.

$\begin{array}{rrr}1 \text { to } 2 \text { feet } & \text { Each } & 10 \\ 2 \text { to } 3 \text { feet. } & \$ 200 \\ 3 & \text { to } 4 \text { feet } \ldots & 300 \\ & \end{array}$

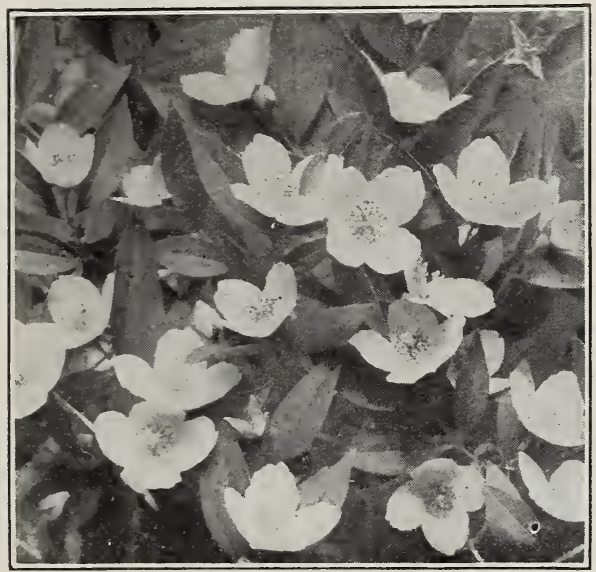

Philadelphus Laxus

A Mass of White and Green in the Spring

Spirea Billardii. Small shrub, with beautiful purplish flowers in long racimes, at end of upright shoots.

Spirea. Pink. A strong growing, woody variety, which blooms profusely small pinkish flowers. Quite pretty.

\section{PRICES ON SPIREA.}

Each

2 to 3 feet......................

3 to 4 feet.................. 40

Wild Honeysuckle. (Azalea Nudiflora.) A deciduous native shrub that produces a profusion of honeysuckle-like flowers in the spring and early summer. Flowers very pretty, peach blossom color, and exceedingly fragrant. Makes a desirable plant for grounds or parks planting.

\section{PRICES-COLLECTED SPECIMENS.}

\section{Each}

2 to 3 feet.....................

3 to 4 feet

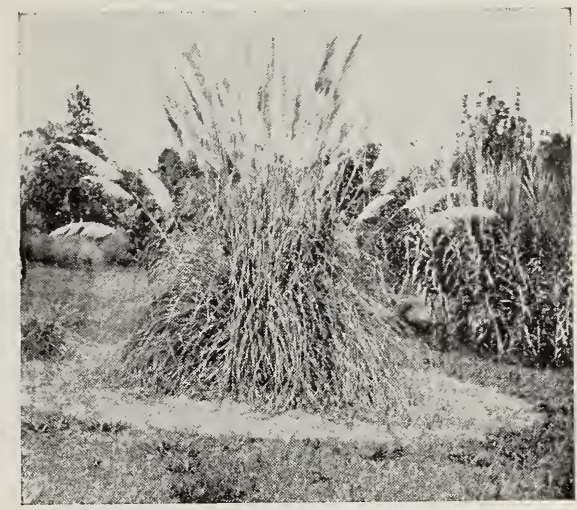

Pampas Grass

Silver Pampas Grass. (Ginerium argentium.) Grows luxuriantly in Florida; the large white plumes are well known. The form of a clump resembles a fountain of water, the leaves curling and reaching to the ground on every side. 35c per set. (Pink Pampas Grass same price.)

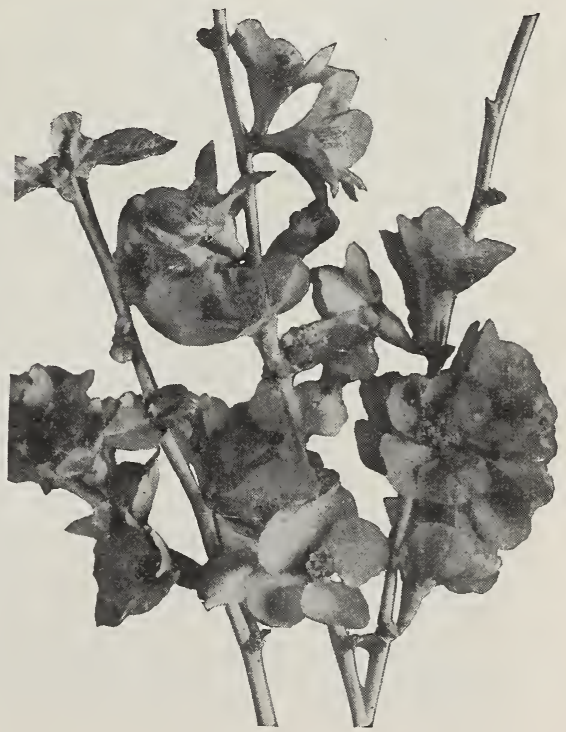

Japan Quince (Cydonia Japonica)

A Profusion of Brilliant Crimson Flowers Come as One of the First Heralds of Spring 


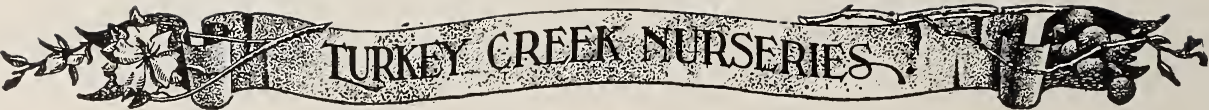 \\ Hedge Plants and Climbing Vines}

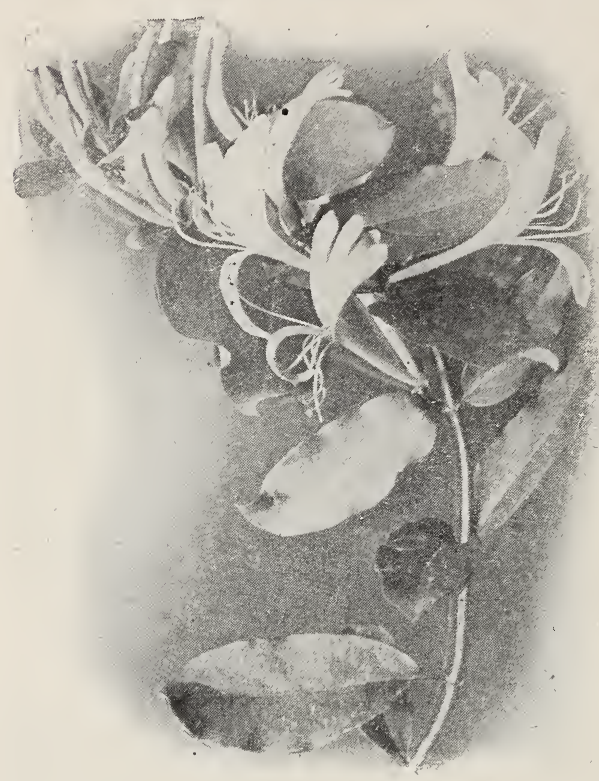

White Honeysuckle

One of the Most Satisfactory Climbers; Profuse and Constant Bloomer; Very Fragrant.

Privet. (Ligustrum.) For borders along walks, or for dividing off grounds, there is nothing so attractive as a well-kept hedge. It adds an air of refinement, and sets off the balance of the grounds. For this purpose Privet is one of the most valuable plants either South or North. It can be easily trained into any desired form.

Amoor River. (Ligustrum Amurence.) Foliage small, light green; flowers white. Extensively used and very popular hedge plant, also desirable for planting as single specimens.

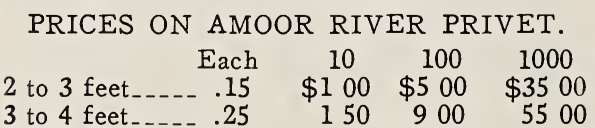

Trumpet Vine. (Bignoniu.) A rankgrowing, clinging vine, suitable for running over fences, rock piles or trellises; will rapidly cover an unsightly object with a mass of green. Flowers deep crimson, beautiful trumpet-shape, about two inches long.

Prices: 1-year vines, 25c each; $\$ 2.00$ per 10 .

English Ivy. (Hedera helix.) A rapid growing, strong climber, soon covers walls or old stumps, fences, or whatever it is planted be- side. Leaves dark green, slightly striped white. Strong layers, 25c each; $\$ 2.00$ per 10.

Honeysuckle. Almost an evergreen. Hardy and vigorous grower. Flowers very fragrant, of a pure white, changing to a yellow. A rank climber. Japan Golden has beautiful goldentinged foliage. Ever blooming. As its name indicates, is almost always in bloom. 2-yearold strong plants, 25c each; $\$ 2.00$ per 10 .

Yellow Jessamine. (Gelsemium Sempervirens.) An evergreen twining vine, stems tangled and matted; rampant grower. Spring bloomer. Flowers deep yellow, very pretty and exceedingly sweet fragrance. Prices: Layers, 25 c each; $\$ 2.00$ per $10 ; \$ 15.00$ per 100 .

Rosa de Montana of Mexico. (Antigonon Leptopus.) A beautiful climbing plant, with tuberous roots, produces freely large racemes of rose-pink flowers of the most exquisite color. Leaves heart-shaped. Very free flowering.

Prices: 1-year layers, 25c each; \$2.00 per 10.

Wisteria. (Wisteria (hinensis.) A magnificent strong growing vine, hardy throughout the country. The flowers, which appear before the leaves in the spring. are produced in large, pointed clusters, blue, white and purple.
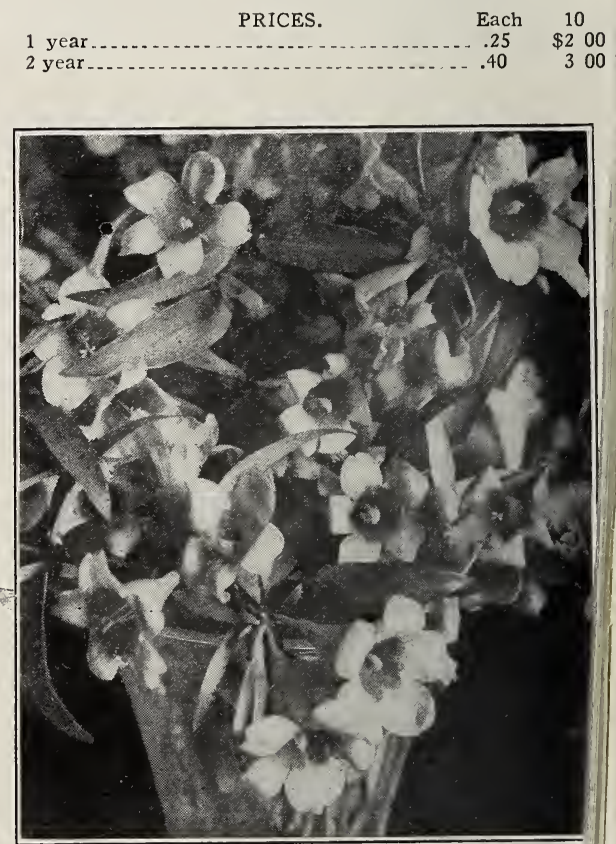

Yellow Jessamine

A fine native vine, flowers very fragrant 


\section{Index}

\begin{tabular}{|c|c|}
\hline PAGE & PAGE \\
\hline 24 & 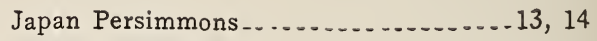 \\
\hline 37 & Japan Quince $\ldots \ldots \ldots \ldots \ldots \ldots \ldots$ \\
\hline tigonon . & Japan Tea Plant ................... 38 \\
\hline$\ldots$ & Kumquats $\ldots \ldots \ldots$ \\
\hline oricots & Laurel .... \\
\hline borvitae & Lemons \\
\hline tea $\ldots$ & Liriodendron $\ldots$ \\
\hline Trees & Loquats $\ldots \ldots \ldots$ \\
\hline gnonia & Magnolia $\ldots \ldots \ldots \ldots$ \\
\hline iota $\ldots$ & Maple \\
\hline Black Gum & Mexican Vine ................... 40 \\
\hline Budded Pecans & 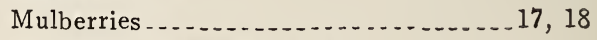 \\
\hline usiness Terms $\ldots \ldots \ldots \ldots$ d cover & Number of Trees per acre \\
\hline thus & 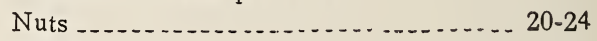 \\
\hline aphor & Oaks _._. 34 \\
\hline Jessamine & Oranges \\
\hline rolina Poplar 32 & Pecans \\
\hline atalpa & Pampas Grass $\ldots$ \\
\hline edrus & Peaches ... \\
\hline Cherry, Wild & Pears \\
\hline y Laurel. & Persimmons \\
\hline 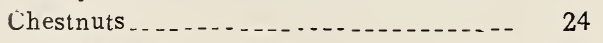 & Philadelphus laxus . . . . . . . . . . . 39 \\
\hline ins & Plums_... \\
\hline Fruits . . . & Pomegranates $\ldots \ldots \ldots \ldots$ \\
\hline Climbers & Pomelos \\
\hline Confederate Rose & Privet \\
\hline Conifers & Prunus Caroliniana . . . . \\
\hline Cottonwood & Quercus \\
\hline Crape Myrtle_...... & Quince \\
\hline Distance to plant.... & Retinospora \\
\hline (2-10 & Roses \\
\hline Ivy & Sassafras $\ldots \ldots$ \\
\hline ymus Japonica & Shade and Ornamental Trees_._. \\
\hline 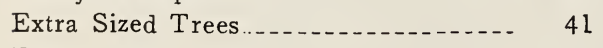 & irea \\
\hline 16 & eet Gum \\
\hline Flowering Shrubs ... & more \\
\hline enia Florida & Tea Plants $\ldots \ldots$ \\
\hline Grape Fruit & Terms of Business \\
\hline Grapes & Texas Cottonwood............. 32 \\
\hline Gum Trees & Texas Umbrella \\
\hline Hedge Plants... 40 & Trumpet Vine \\
\hline 37 & Tulip Tree \\
\hline uckle & Vines \\
\hline rry & auts \\
\hline (2-1 & Vild Cherry.. \\
\hline Ivy & Yellow Jessamine \\
\hline
\end{tabular}

Copyright 1911 by Turkey Creek Nurseries

PEPPER PUB. \& PIG. CO., GAII:LSVILLE, FLA. 

Turkey Creek Nurseries

Macclenny, Florida

U. S. A.

\section{ORDER SHEET.}

C. F. BARBER, Presiden?

J. E. BARBER,

\section{NOTICE.}

Read carefully "Terms and Conditions" before writing order. Please use this Order Sluevt. Extra Order Shets sent on request.

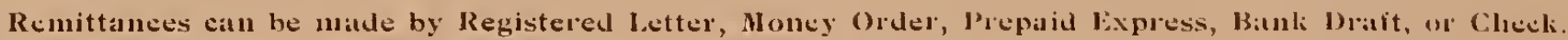

Shall we substitute varieties or sizes in ease those ordered are cilnansted. Write "Yes" or "No." Unless instructed to the emtrary, we substitute where necessilly.

\section{TURKEY CREEK NURSERIES,}

Date

\section{Geatlemen:}

\section{MACCLENNY, FLORIDA}

Ship the following nursery stock by

(Frelght," "Express" or" Use your diecrution.")

for which l enclose $\$$

Fer Full Shipping Address.

Name

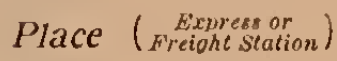

County... State

Via

PeO Postofice Address of Purchaser.

Name

Street and No. or
P. O. Box

Postoffice.

County ……....................... State 


From

\title{
Turkey Creek Nurseries
}

\author{
Macclenny
}

Florida 



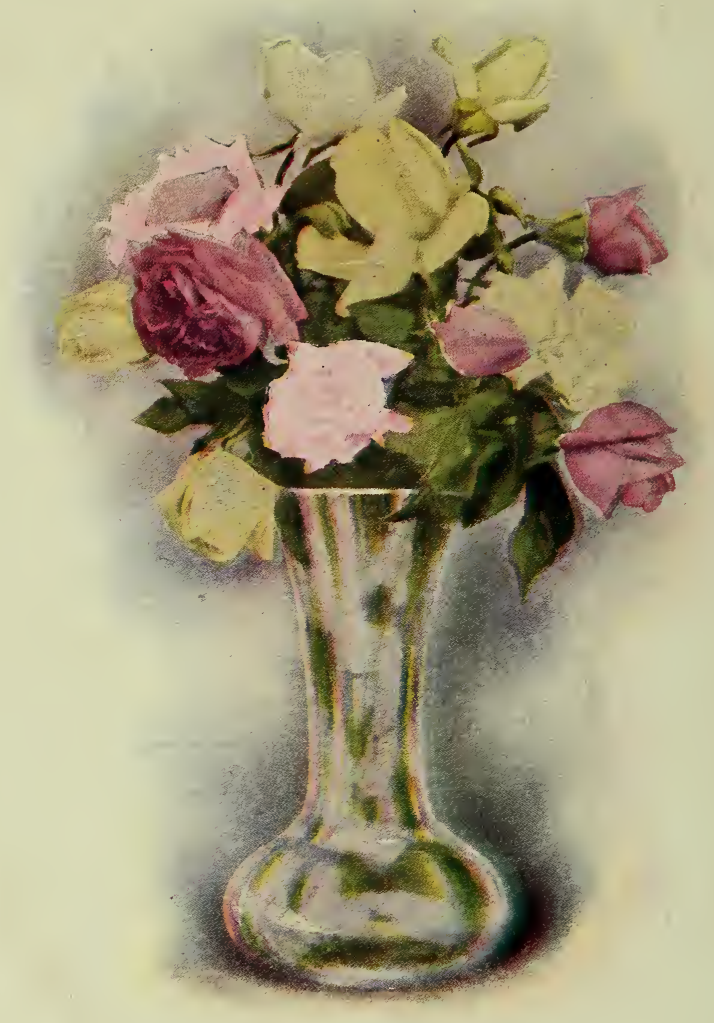

Curkey Creek I2urseries

INCORPORATED

macclenny, Florida 